\title{
Determining Sources of Water and Contaminants to Wells in a Carbonate Aquifer Near Martinsburg, Blair County, Pennsylvania, By Use of Geochemical Indicators, Analysis of Anthropogenic Contaminants, and Simulation of Ground-Water Flow
}

By Bruce D. Lindsey and Michele L. Koch 


\title{
U.S. Department of the Interior Gale A. Norton, Secretary
}

\author{
U.S. Geological Survey \\ Charles G. Groat, Director
}

U.S. Geological Survey, Reston, Virginia: 2004

For sale by U.S. Geological Survey, Information Services

Box 25286, Denver Federal Center

Denver, CO 80225

For more information about the USGS and its products:

Telephone: 1-888-ASK-USGS

World Wide Web: http://www.usgs.gov/

Any use of trade, product, or firm names in this publication is for descriptive purposes only and does not imply endorsement by the U.S. Government.

Although this report is in the public domain, permission must be secured from the individual copyright owners to reproduce any copyrighted materials contained within this report. 


\section{Contents}

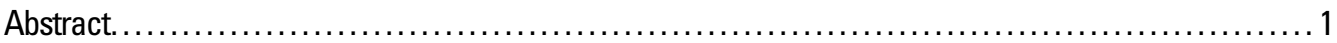

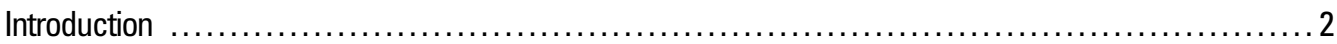

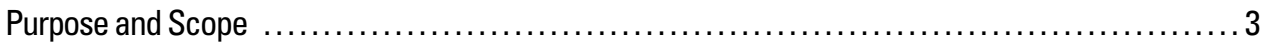

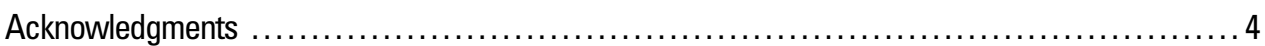

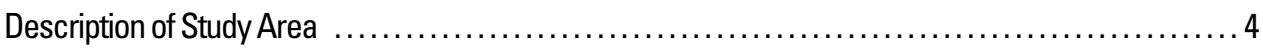

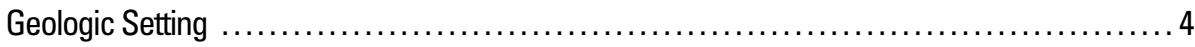

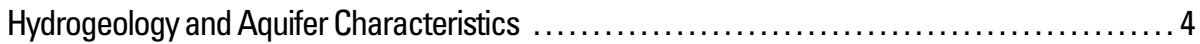

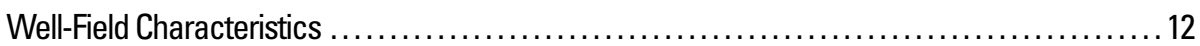

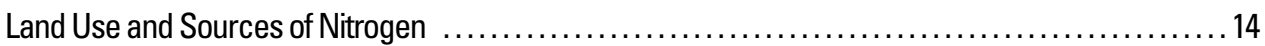

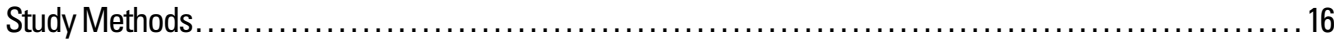

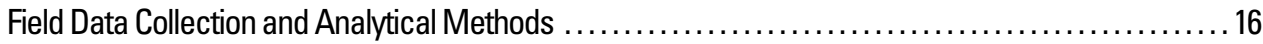

Methods to Determine Sources of Contaminants to Ground-Water Wells .................... 18

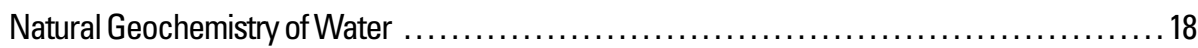

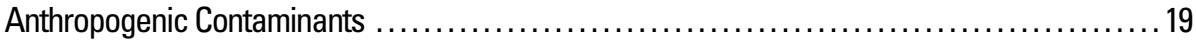

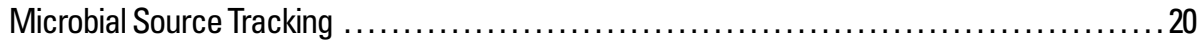

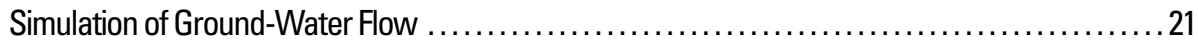

Sources of Water and Contaminants to Martinsburg Municipal Wells ..........................22

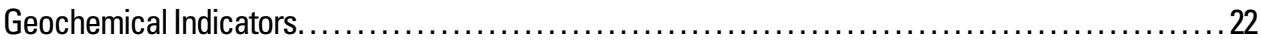

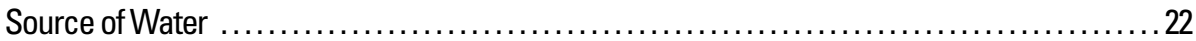

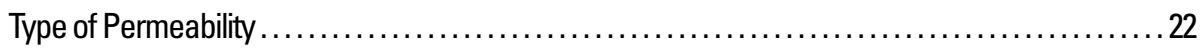

Sources Based on Analysis of Anthropogenic Contaminants........................... 24

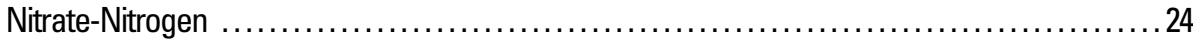

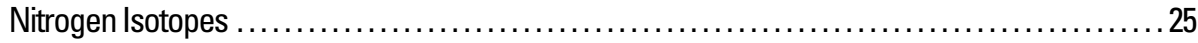

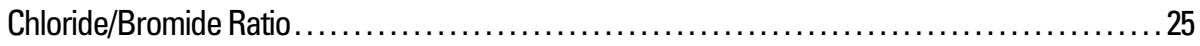

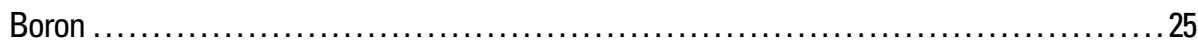

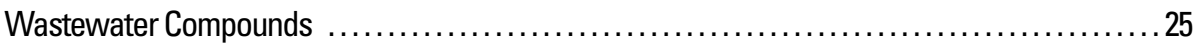

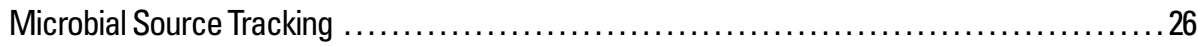

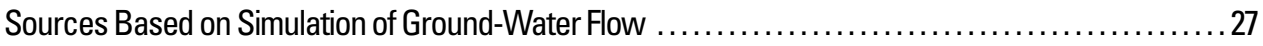

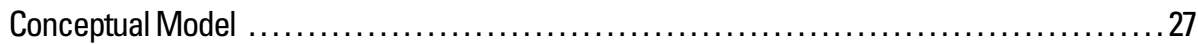

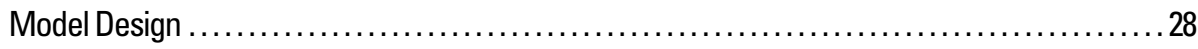

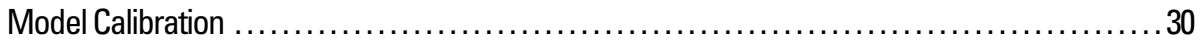

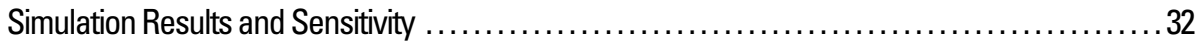

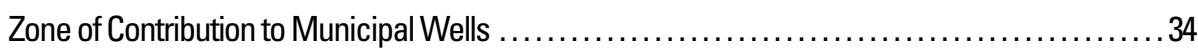

Relating Simulation Results, Natural Geochemistry, and Anthropogenic Contaminants to Determine Source Areas ........................39

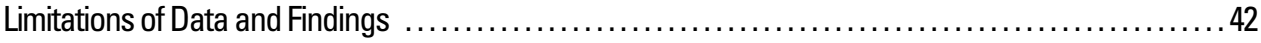

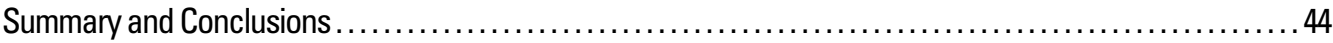

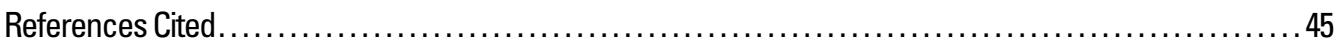




\section{Figures}

1-3. Maps showing:

1. Location of the Ridge and Valley Physiographic Province, carbonate bedrock in Pennsylvania, and the Borough of Martinsburg, Pennsylvania. ...

2. Location of the Morrison Cove Valley, Martinsburg, Pennsylvania, boundary of ground-water model area, and land use

3. Geologic formations, structure, and geologic section in the study area near

Martinsburg, Pennsylvania.

4. Shaded-relief map of the Martinsburg, Pennsylvania Quadrangle showing topography, lithology, and stream drainage near Martinsburg, Pennsylvania ...................... 6

5. Conceptual model of ground-water-flow system near Martinsburg, Pennsylvania ..........9

6. Map showing basic soil types and their relation to bedrock lithology near Martinsburg, Pennsylvania .

7. Conceptual model of hypothetical orientation of major fracture sets in study area near Martinsburg, Pennsylvania .... 10

8-12. Maps showing:

8. Karst features within ground-water model boundary near Martinsburg, Pennsylvania

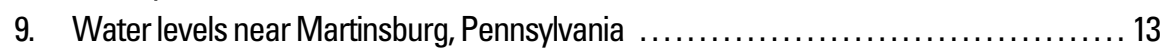

10. Generalized land use in the area of Martinsburg, Pennsylvania 14

11. Types of nitrogen applied to fields and areas served by public sewer lines near Martinsburg, Pennsylvania........................................... 15

12. Location of wells, springs, and streams sampled or measured in and near Martinsburg, Pennsylvania

13. Graph showing $\delta^{15} \mathrm{~N}$ relative to organic carbon: total nitrogen for $(\mathrm{A})$ nitrogen-source materials; and (B) suspended particulates in water, Susquehanna River Basin, Pennsylvania

14. Piper diagram showing concentrations of major ions in water from wells near Martinsburg, Pennsylvania.

15. Graph showing binary mixing curves for chloride to bromide ratios for water from wells and streams near Martinsburg, Pennsylvania.

16. Map showing location of model grid, boundaries, streams, drain nodes, and wells near Martinsburg, Pennsylvania........................................... 28

17. Hypothetical cross section of model layers used for simulation of ground-water flow . . . . . 29 18-19. Graphs showing:

18. Composite scaled sensitivities for parameters used in model calibration 31

19. Calibration results showing simulated and measured water levels near Martinsburg, Pennsylvania 14 5 


\section{Figures-Continued}

25-28. Maps showing:

25. Areal extent of zone of contribution to wells near Martinsburg, Pennsylvania, illustrating simulation with horizontal anisotropy and without horizontal

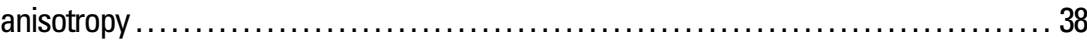

26. Geology and karst features in the areal extent of the zone of contribution to well BA 332 and well BA 545 near Martinsburg, Pennsylvania....................... 40

27. Land use in the areal extent of the zone of contribution to well BA 332 and BA 545

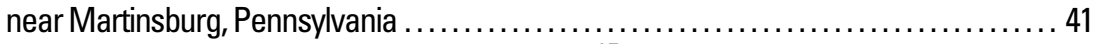

28. Sources of nitrogen, nitrate concentration, and $\delta^{15} \mathrm{~N}$ in municipal wells near Martinsburg, Pennsylvania

\section{Tables}

1. Geologic-stratigraphic and hydrologic units column near Martinsburg, Blair County, Pennsylvania .7

2. Hydrogeologic properties of aquifers in the study area $\ldots \ldots \ldots \ldots \ldots \ldots \ldots \ldots \ldots \ldots \ldots$

3. Land covers included in the land-use groupings in the study area near Martinsburg,

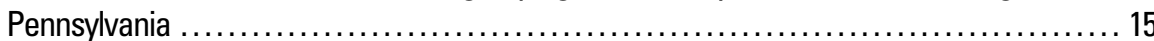

4. Wells sampled and/or used for model calibration near Martinsburg, Pennsylvania ........ 17

5. Sampling requirements and analytical methods for water analyses from wells and streams near Martinsburg, Pennsylvania . ................................... 18

6. Data from previous studies of water from Ridge and Valley carbonate aquifers in Pennsylvania showing geochemical indicators of source of water ................... 19

7. Data on geochemical indicators of type of permeability from previous studies of Ridge and Valley carbonate aquifers in Pennsylvania ............................... 19

8. Geochemical composition of water from wells sampled near Martinsburg, Pennsylvania ... 23

9. Selected chemical analyses from wells, springs, and a spring sampled near

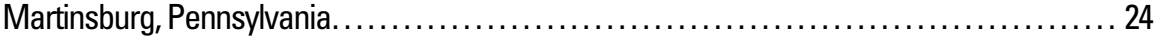

10. Optimum values of aquifer properties estimated near Martinsburg, Pennsylvania . ......... 33

11. Water budget for steady-state simulation near Martinsburg, Pennsylvania ............... 33 


\section{Conversion Factors and Abbreviations}

\begin{tabular}{|c|c|c|}
\hline Multiply & By & To obtain \\
\hline \multicolumn{3}{|c|}{ Length } \\
\hline inch (in.) & 0.0254 & meter $(\mathrm{m})$ \\
\hline foot $(\mathrm{ft})$ & 0.3048 & meter $(\mathrm{m})$ \\
\hline mile (mi) & 1609.3 & meter $(\mathrm{m})$ \\
\hline \multicolumn{3}{|c|}{ Area } \\
\hline square mile $\left(\mathrm{mi}^{2}\right)$ & 2.590 & square kilometer $\left(\mathrm{km}^{2}\right)$ \\
\hline \multicolumn{3}{|c|}{ Volume } \\
\hline gallon (gal) & 0.00022 & milliliter (mL) \\
\hline gallon (gal) & 3.785 & liter $(\mathrm{L})$ \\
\hline \multicolumn{3}{|c|}{ Flow Rate } \\
\hline foot per day $(\mathrm{ft} / \mathrm{d})$ & 0.3048 & meter per day $(\mathrm{m} / \mathrm{d})$ \\
\hline gallon per minute (gal/min) & 0.06309 & liter per second (L/s) \\
\hline gallon per day (gal/d) & 0.003785 & cubic meter per day $\left(\mathrm{m}^{3} / \mathrm{d}\right)$ \\
\hline cubic foot per second $\left(\mathrm{ft}^{3} / \mathrm{s}\right)$ & 0.0283 & cubic meters per second $\left(\mathrm{m}^{3} / \mathrm{s}\right)$ \\
\hline inch per year (in/yr) & 25.4 & millimeter per year (mm/yr) \\
\hline \multicolumn{3}{|c|}{ Specific capacity } \\
\hline $\begin{array}{l}\text { gallon per minute per foot } \\
[(\mathrm{gal} / \mathrm{min}) / \mathrm{ft})]\end{array}$ & 0.2070 & liter per second per meter $\left(\mathrm{L} / \mathrm{s} / \mathrm{m}^{2}\right)$ \\
\hline \multicolumn{3}{|c|}{ Temperature } \\
\hline degree Fahrenheit $\left({ }^{\circ} \mathrm{F}\right)$ & ${ }^{\circ} \mathrm{C}=5 / 9\left({ }^{\circ} \mathrm{F}-32\right)$ & degree Celsius \\
\hline
\end{tabular}

Specific conductance is given in microsiemens per centimeter at 25 degrees Celsius $\left(\mu \mathrm{S} / \mathrm{cm}\right.$ at $25^{\circ} \mathrm{C}$ ).

Concentrations of chemical constituents in water are given either in milligrams per liter (mg/L) or micrograms per liter $(\mu \mathrm{g} / \mathrm{L})$.

Vertical coordinate information is referenced to National Geodetic Vertical Datum of 1929 (NGVD 29); horizontal coordinate information is referenced to the North American Datum of 1983 (NAD 83).

Per mil: A unit expressing the ratio of stable isotopic abundance of an element in a sample to those of a standard material. Per mil units are equivalent to parts per thousand. Stable-isotopic ratios are computed as follows (Kendall and Caldwell, 1998):

$$
\delta \mathrm{X}=\left(R_{\text {sample }} / R_{\text {standard }}-1\right) \times 1,000
$$

where $\mathrm{X}$ is the heavier stable isotope and $\mathrm{R}$ is the ratio of the heavier, less abundant isotope to the lighter stable isotope in a sample or standard. The $\delta$ values for nitrogen stable-isotopic ratios discussed in this report are referenced to the following standard materials: Nitrogen-15: nitrogen-14, Standard atmospheric nitrogen, referenced to the National Bureau of Standards, NBS-14 nitrogen gas. 


\section{Determining Sources of Water and Contaminants to Wells in a Carbonate Aquifer near Martinsburg, Blair County, Pennsylvania, by Use of Geochemical Indicators, Analysis of Anthropogenic Contaminants, and Simulation of Ground-Water Flow}

by Bruce D. Lindsey and Michele L. Koch

\section{Abstract}

Water supply for the Borough of Martinsburg, Pa., is from two well fields (Wineland and Hershberger) completed in carbonate-bedrock aquifers in the Morrison Cove Valley. Water supply is plentiful; however, waters with high concentrations of nitrate are a concern. This report describes the sources of water and contaminants to the supply wells. A review of previous investigations was used to establish the aquifer framework and estimate aquifer hydraulic properties. Aquifer framework and simulation of ground-water flow in a 25 -square-mile area using the MODFLOW model helped to further constrain aquifer hydraulic properties and identify water-source areas in the zone of contribution of ground water to the well fields. Flow simulation identified potential contaminant-source areas. Data on contaminants and geochemical characteristics of ground water at the well fields were compared to the results of flow simulation.

The Woodbury Anticline controls the aquifer framework near the well fields and four carbonate-bedrock formations contain the primary aquifers. Three carbonate-bedrock aquifers of Ordovician age overlie the Gatesburg aquifer of Cambrian age on the flanks of the anticline. Fracture, not conduit, permeability was determined to be the dominant water-bearing characteristic of the bedrock. The horizontal hydraulic conductivity of the Gatesburg aquifer is about 36 feet per day. The other carbonate aquifers (Nittany/Stonehenge, Bellefonte/Axemann, and Coburn through Loysburg aquifers) overlying and flanking the Gatesburg aquifer have horizontal hydraulic conductivities of about 1 foot per day. Regional directions of ground-water flow are toward the major streams with Clover Creek as the major discharge point for ground water in the east. Ground-water flow to the well fields is anisotropic with a 5:1 preferential horizontal direction along strike of the axial fold of the anticline. Thus, the zone of contribution of ground water to the well fields is elongate in a north-south direction along the anticline axis, with the majority of the flow to the well fields originating from the south.
Human activity in the areal extent of the zone of contribution to the well fields was the source of contaminants. The areal extent of the zone of contribution included both urban areas in the Borough and a large amount of agricultural land. By relating results of flow simulation, natural geochemistry, and analyses of anthropogenic (human-made) contaminants, the source areas for water and contaminants were determined with more confidence than by using only flow simulation. Analysis of natural geochemistry identified water sources from both limestone and dolomite aquifers. Geochemistry results also indicated fractures, not conduits, were the dominant source of water from aquifers; however, quantitative source identification was not possible. Chemical ratios of chloride and bromide were useful to show that all samples of ground water had sources with chemical contributions from land surface. Nitrogen isotope ratio analysis indicated animal manure as the possible primary source of nitrate in most ground water. Some of the nitrate in ground water had chemical fertilizer as a source. At the Wineland well field, chemical fertilizer was likely the source of nitrate. The nitrate in water from the Hershberger well field was from a mixture of fertilizer and animal-manure sources. Human sewage was ruled out as a major source of nitrate in water from the municipal wells by results showing 1) wastewater compounds in sewage were rarely detected and 2) a mass-balance calculation indicating the small contribution of nitrogen that could be attributed to septic systems. 


\section{Determining Sources of Water and Contaminants to Wells in a Carbonate Aquifer near Martinsburg, Pennsylvania}

\section{Introduction}

Ground water is an essential resource for residents of Pennsylvania. In many rural areas, ground water is the only source of water for domestic supply. Ground water also can be the major source for municipal water supply in rural communities underlain by carbonate bedrock. Because of the karst topography characteristics in these carbonate-bedrock areas, the network of streams can be less dense than in other areas, making ground water the only available source of supply. The Borough of Martinsburg is a rural community in Blair County, Pa.

(fig. 1), that relies on ground-water supply from a carbonatebedrock aquifer, hereinafter termed the carbonate aquifer. Martinsburg has four wells that supply the local population of approximately 3,140 persons, with 1,200 service connections (Randy Stoltz, Martinsburg Municipal Authority, written commun., 2002). The daily water usage is about $300,000 \mathrm{gal} / \mathrm{d}$ from two well fields (Wineland and Hershberger). The supply of water from the four municipal wells is plentiful; however, the quality of the water is a concern. On a few occasions, concentrations of nitrate in water from the municipal wells have exceeded the U.S. Environmental Protection Agency (USEPA) Maximum Contaminant Level (MCL) of $10 \mathrm{mg} / \mathrm{L}$ as nitrogen
(U.S. Environmental Protection Agency, 2002) (Randy Stoltz, Martinsburg Municipal Authority, written commun., 2002). If the water from these wells continues to exceed the USEPA MCL, the Martinsburg Municipal Authority will be obligated to mitigate the problem by either finding another source of water or treating the water by installing a nitrate-removal system. Other sources of water, including surface water, are not readily available. Water from new wells installed in the carbonate aquifer would be likely to have similar nitrate concentrations. A treatment system for nitrate removal is likely to be an expensive option (Randy Stoltz, Martinsburg Municipal Authority, oral commun., 2002). Therefore, another alternative would be to determine the source of nitrate contamination and to attempt to mitigate the problem by reducing or eliminating the source.

High concentrations of nitrate in ground water are not isolated to the Martinsburg municipal supply wells. The U.S. Geological Survey (USGS) conducted a study of ground-water quality in the Lower Susquehanna River Basin that included the Martinsburg area (Lindsey and others, 1997; Siwiec and others, 1997, p. 92-93). The USGS reported the median nitrate concentration at $9 \mathrm{mg} / \mathrm{L}$ as nitrogen in the area that included the Martinsburg area. The Pennsylvania Department of Agriculture

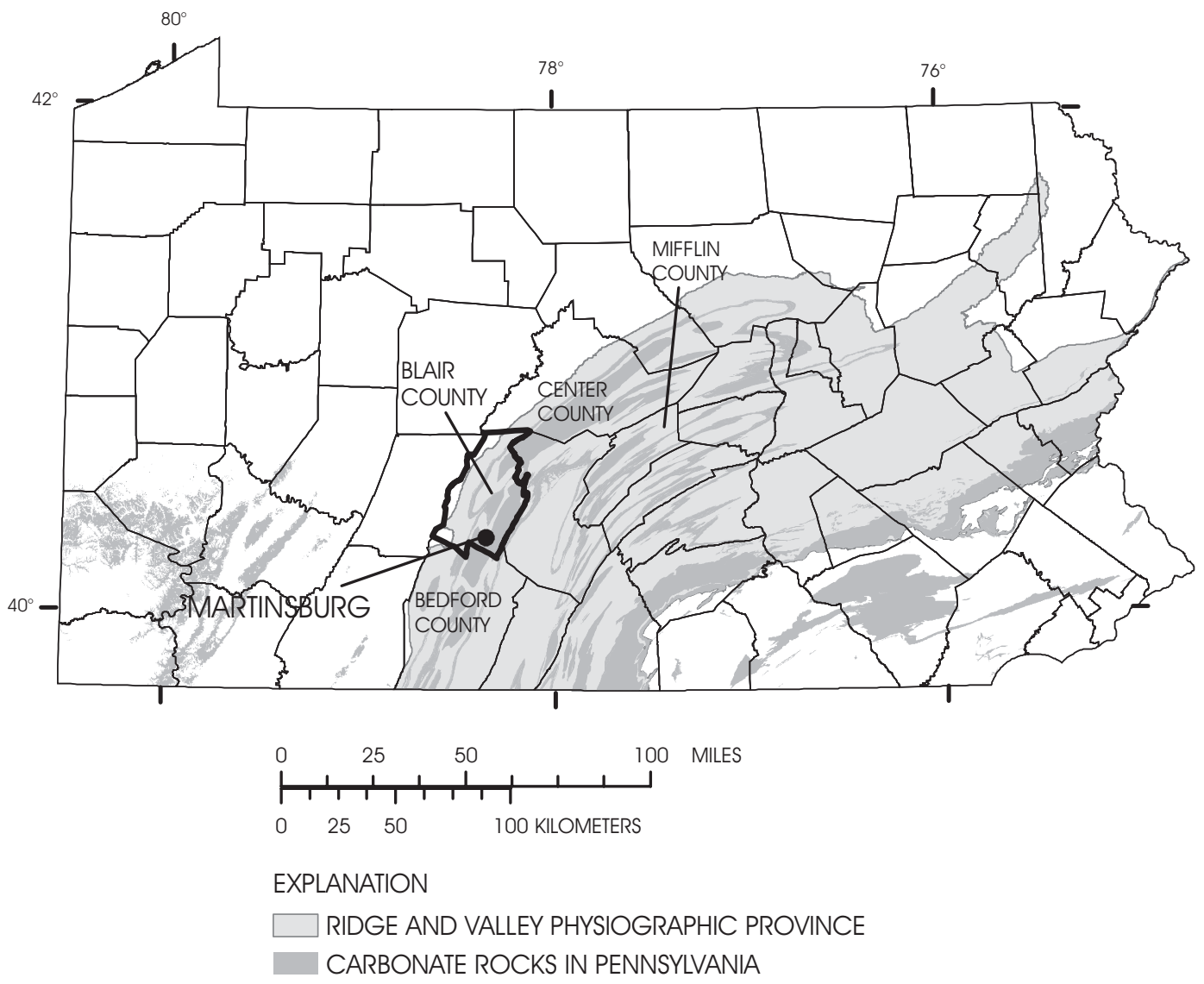

Figure 1. Location of the Ridge and Valley Physiographic Province (Sevon, 2000), carbonate bedrock in Pennsylvania (Berg and others, 1980), and the Borough of Martinsburg, Pennsylvania. 
conducted a study of pesticides, nitrate, and bacteria in rural wells (Coyle, 1998). During the Pennsylvania Department of Agriculture study, 189 wells were sampled in southern Blair County and northern Bedford County (Morrison Cove Valley, fig. 2), and water from about 35 percent of the wells sampled exceeded the USEPA MCL for nitrate. To address concerns about high nitrate concentrations in ground water, the USGS, in cooperation with the Southern Alleghenies Conservancy and the Borough of Martinsburg, conducted a study of the sources of water and contaminants to the Martinsburg municipal supply wells.

The Borough of Martinsburg is surrounded by agricultural and low-density residential land use. Fertilizers, animal manure, and on-lot septic systems are all potential sources of nitrate that could cause concentrations in ground water to approach or exceed the USEPA MCL. Because these potential sources are found in virtually every direction around the well fields, it is necessary to delineate the areal extent of the zone of contribution that supplies water to the wells in order to identify the nitrate source.

\section{Purpose and Scope}

This report defines sources of water and contaminants to wells in a carbonate aquifer near Martinsburg, Pa., by use of geochemical indicators, analysis of anthropogenic contami- nants, and simulation of ground-water flow. The areal extent of the zone of contribution of water to the four supply wells used by the Martinsburg Municipal Authority, Blair County, Pa., is estimated. This report includes interpretations of water-quality analyses collected in September 2002, water levels measured in 16 wells in September 2002, streamflow discharge measured in 1 spring and 4 streams during September and November 2002, and simulation of ground-water flow under steady-state conditions. The results of water-quality sampling are compared to results of ground-water modeling and are used to assess the accuracy of the areal extent of the zone of contribution delineated by the model. The study focused on a $25-\mathrm{mi}^{2}$ area around the Borough of Martinsburg.

The areal extent of the zone of contribution, assuming no induced infiltration from streams, is the aquifer volume through which water is drawn to a well, projected to the land surface (Risser and Barton, 1995). A rigorous approach to determine the areal extent of the zones of contribution to wells commonly includes ground-water-flow modeling. In areas of fractured bedrock and, in particular, areas underlain by carbonate bedrock, predictions of ground-water-flow direction using groundwater-flow models can be uncertain. This uncertainty results because some of the underlying assumptions of the model used here, such as a porous medium and a homogeneous, isotropic aquifer, are not entirely accurate.

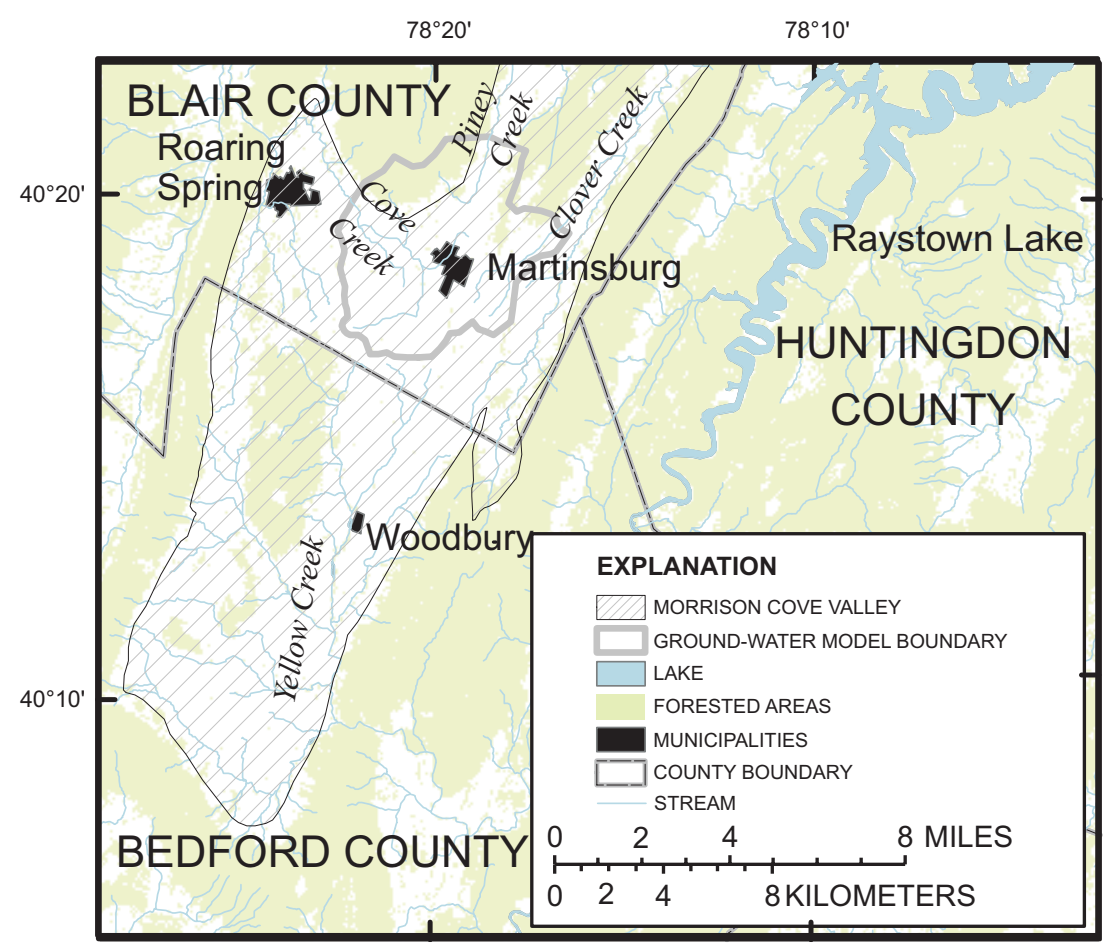

Figure 2. Location of the Morrison Cove Valley, Martinsburg, Pennsylvania, boundary of ground-water model area, and land use (Vogelmann and others, 1998a, 1998b). 


\section{Acknowledgments}

The authors would like to thank the following individuals for assisting in developing the project: Randy Stoltz, Martinsburg Borough; Len Lichvar, Southern Alleghenies Conservancy; Ron Donlan, Southern Alleghenies Resource Conservation and Development; Janie French, Canaan Valley Institute; and Amanda Ritchy, U.S. Department of Agriculture, National Resources Conservation Service. The authors also would like to express their thanks to all the homeowners who participated in the project by allowing their wells to be sampled.

\section{Description of Study Area}

Martinsburg is in the Ridge and Valley Physiographic Province (fig. 1) (Sevon, 2000). The Ridge and Valley Physiographic Province is a series of long, narrow, resistant ridges and broad to narrow valleys. Martinsburg is in a valley known as Morrison Cove (fig. 2). The $25-\mathrm{mi}^{2}$ area around the municipal wells that was the focus of this study is referred to as the ground-water model area (fig. 4).

\section{Geologic Setting}

Morrison Cove Valley is underlain by layers of folded bedrock that consist predominantly of Cambrian- and Ordovicianage limestone and dolomite. The flanking ridges consist of Ordovician- and Silurian-age sandstones, siltstones, and shales (figs. 3 and 4). The limestone and dolomite in the valley are weathered easily by acidic water. Because of its mineral composition, carbonate bedrock commonly is highly weathered in the subsurface as well. The ridges in the Martinsburg area are underlain by sandstone that is more resistant to weathering. Shale units also are present in the valley. Shale is more resistant to weathering than the carbonate rocks, but less resistant than sandstone.

Two major structural features are in the study area. The Woodbury Anticline runs generally north and south through the valley with the axis of the anticline being east of Martinsburg (fig. 3). The Scotch Valley Syncline parallels this structure further west in the valley. Bedding has a strike of about N. $30^{\circ} \mathrm{E}$., and dip angles range from $60^{\circ}$ to $80^{\circ} \mathrm{NW}$., between the anticline and the syncline (Butts, 1945).

\section{Hydrogeology and Aquifer Characteristics}

A study of ground water in the Cambrian and Ordovician carbonate rocks in the Ridge and Valley Physiographic Province by Becher (1996) provided the basic information about hydrogeology and aquifer characteristics used in this study. Becher noted that municipalities in this area were highly dependent on ground water as a source of supply and that wells in the Gatesburg and Nittany/Stonehenge aquifers (the aquifers in which the Martinsburg wells in the Wineland and Hershberger well fields are completed) had the highest yields of all the aqui- fers studied, with yields as great as $1,000 \mathrm{gal} / \mathrm{min}$ reported. Additional information on geologic and aquifer characteristics from Becher (1996) is summarized in tables 1 and 2. Not listed in table 2 are the Juniata, Bald Eagle, and Waynesboro aquifers. The Tuscarora, Juniata, and Bald Eagle aquifers typically underlie ridges, and generally are considered low-yielding aquifers (Taylor and others, 1982). The Reedsville and Waynesboro aquifers also are considered to yield small to moderate amounts of water (Taylor and others, 1982).

The term 'aquifer,' as used in this report, refers to that part of the geologic formation that is close enough to the land surface to be in the active part of the ground-water-flow system. Most of the geologic formations are tilted on the flanks of an anticlinal or synclinal structure (fig. 3), and, therefore, the water-bearing part of the aquifer includes only that part of the geologic formation in the active ground-water-flow system (fig. 5). Also, because of the tilted nature of the bedrock, the thicknesses, or sum of the thicknesses of the geologic formations given in table 1 may not be equal to the depth of the geologic formation or aquifer.

The conceptual model of a flow system controlled by depth and lithology proposed by Gerhart and Lazorchick (1988) for ground-water flow in fractured bedrock was used as a basis for this study. Gerhart and Lazorchick (1988) found that the density of fractures and, subsequently, the hydraulic conductivity decreased with depth as illustrated schematically in fig. 5 . The water-bearing capacity of a given aquifer, therefore, would be greater near the land surface and decrease with depth to a point where ground-water flow is negligible. Because of the decreasing fracture density with depth, water flowing in the deep part of the aquifer would follow a more tortuous flow path (fig. 5) through a medium with a lower transmissivity than water flowing in the shallow part of the aquifer. Thus, water flowing through the deeper part of the system would make up a smaller proportion of the total water budget than water flowing in the shallow part. Another basic assumption in the conceptual model was that ground-water flow varies on the basis of lithology because of variations that affect hydraulic conductivity (such as porosity, permeability, and weathering of fractures) among the different rock types. The four basic lithologies in the study area are shale, sandstone, limestone, and dolomite. Most of the carbonate aquifers as mapped locally include limestone and dolomite members; for example, the Nittany/Stonehenge aquifer is mapped as one unit but includes the Nittany aquifer (dolomite) and the Stonehenge aquifer (limestone). Therefore, Nittany/Stonehenge, Bellefonte/Axemann, and Coburn through Loysburg aquifers were considered as mixed limestone and dolomite and not separated in the conceptual model. The exception to this was the Gatesburg aquifer, which has distinct hydrogeologic properties (Becher, 1996) and geochemical properties (Langmuir and White, 1971) and was therefore considered a separate hydrogeologic unit in the conceptual model (fig. 5). The four hydrogeologic units in this study were sandstone, shale, mixed limestone/dolomite, and dolomite (the Gatesburg aquifer). 


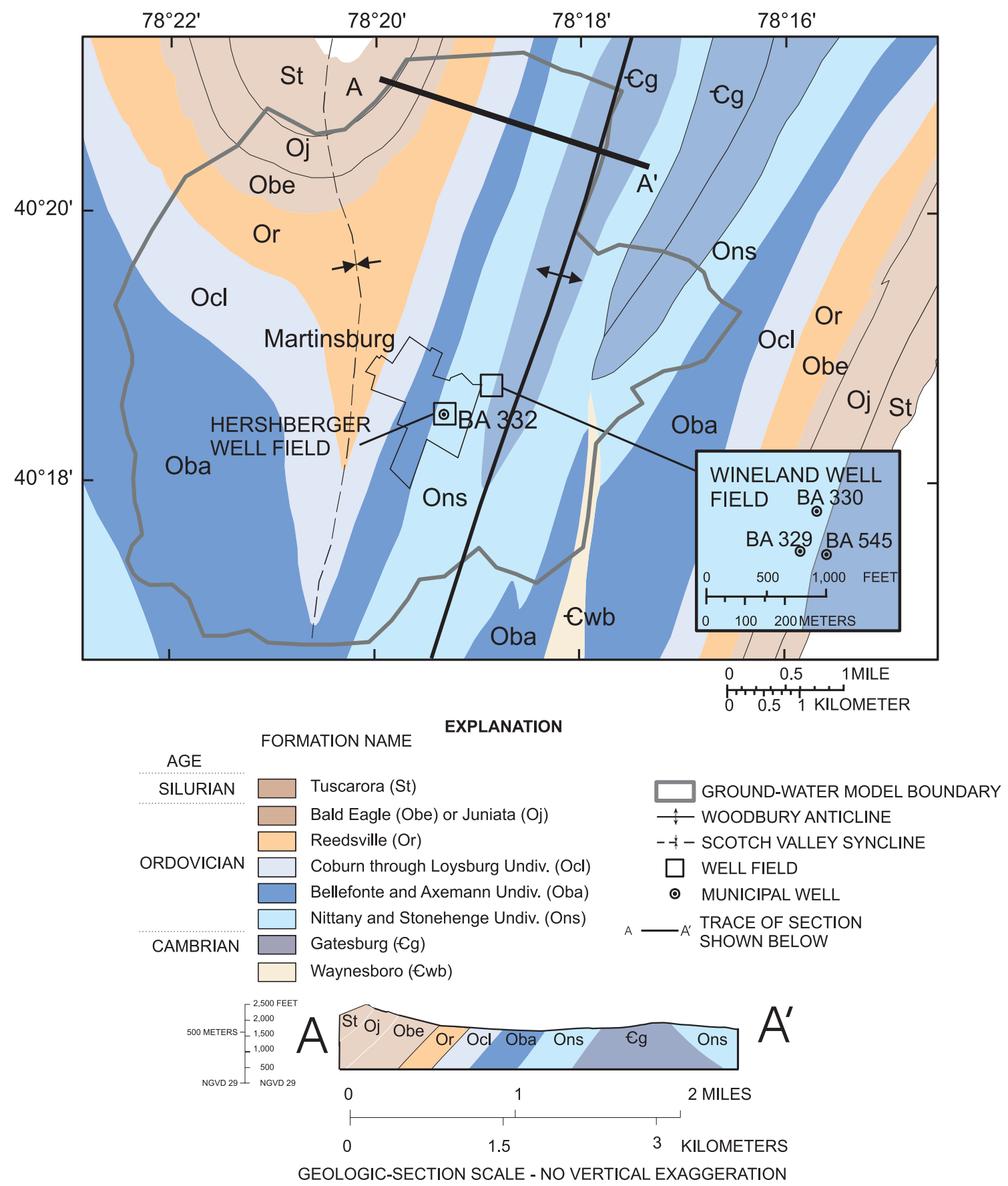

Figure 3. Geologic formations (Berg and others, 1980), structure, and geologic section (modified from Butts, 1945) in the study area near Martinsburg, Pennsylvania. 


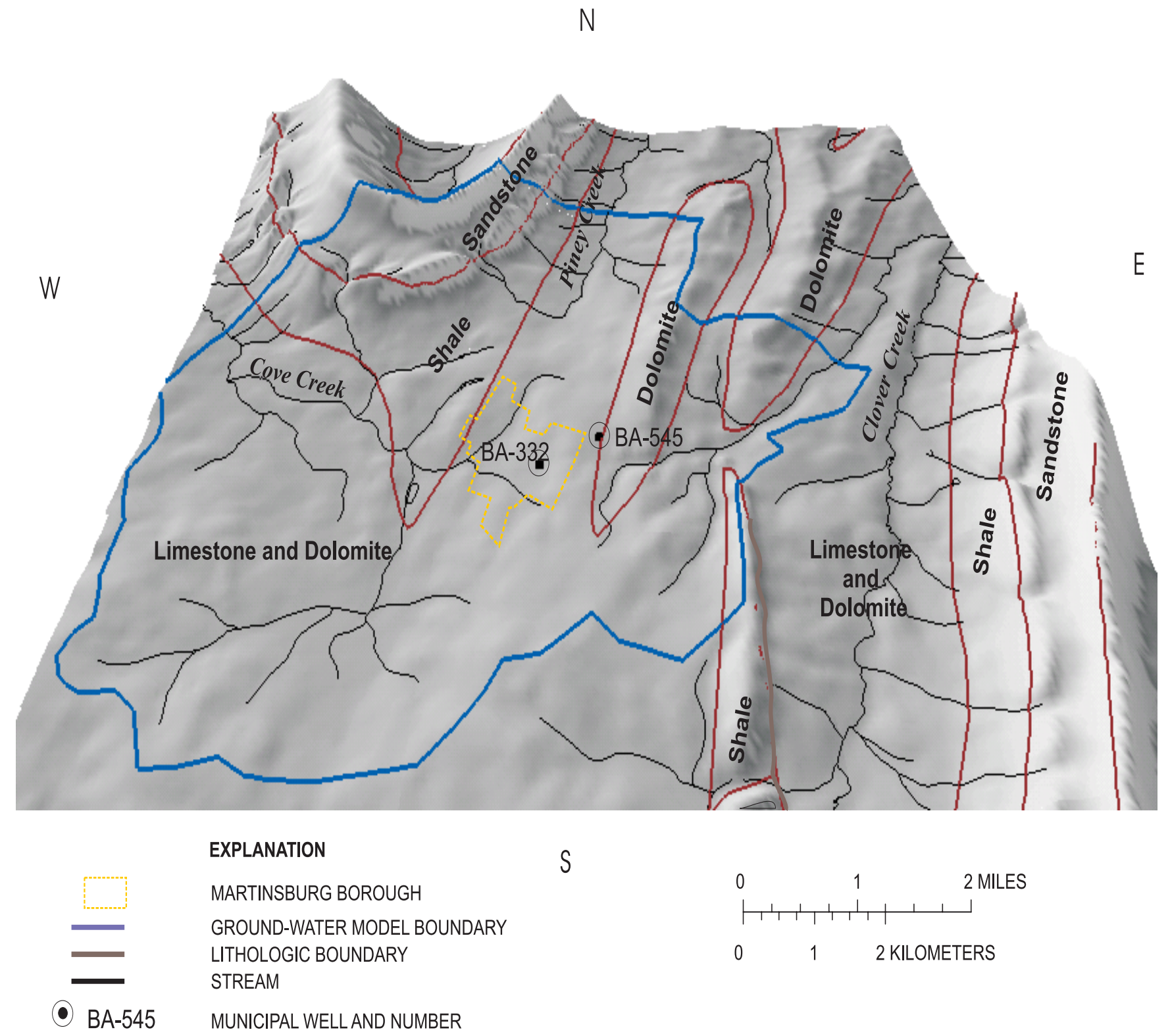

Figure 4. Shaded-relief map of the Martinsburg, Pennsylvania Quadrangle showing topography, lithology, and stream drainage near Martinsburg, Pennsylvania. (vertical exaggeration X 2.5) 
Table 1. Geologic-stratigraphic and hydrologic units column near Martinsburg, Blair County, Pennsylvania.

[Descriptions from Becher, 1996]

\begin{tabular}{|c|c|c|c|c|}
\hline $\begin{array}{l}\text { Geologic } \\
\text { age }\end{array}$ & $\begin{array}{l}\text { Geologic formation } \\
\text { and abbreviation } \\
\text { (units as mapped locally) }\end{array}$ & Geologic description & $\begin{array}{l}\text { Thickness } \\
\text { (feet) }\end{array}$ & $\begin{array}{l}\text { Hydrologic unit } \\
\text { (lithology) }\end{array}$ \\
\hline Silurian & $\begin{array}{l}\text { Tuscarora } \\
\text { St }\end{array}$ & $\begin{array}{l}\text { Light- to medium-gray sandstone and minor } \\
\text { interbedded shale. }\end{array}$ & $400-700$ & $\begin{array}{l}\text { Tuscarora, Juniata, and Bald } \\
\text { Eagle aquifers (sandstone) }\end{array}$ \\
\hline \multirow[t]{12}{*}{ Ordovician } & $\begin{array}{l}\text { Juniata } \\
\text { Oj }\end{array}$ & $\begin{array}{l}\text { Brownish- to grayish-red sandstone and some } \\
\text { siltstone and shale. }\end{array}$ & 850 & \\
\hline & $\begin{array}{l}\text { Bald Eagle } \\
\text { Obe }\end{array}$ & $\begin{array}{l}\text { Gray to olive-gray and grayish-red fine- to } \\
\text { coarse-grained sandstone and some } \\
\text { conglomerate. }\end{array}$ & $600-900$ & \\
\hline & $\begin{array}{l}\text { Reedsville } \\
\text { Or }\end{array}$ & $\begin{array}{l}\text { Medium dark-gray to brownish or greenish- } \\
\text { gray shale with some interbedded siltstone } \\
\text { and sandstone beds. }\end{array}$ & $1,000-2,000$ & $\begin{array}{l}\text { Reedsville and Waynesboro } \\
\text { aquifer (shale) }\end{array}$ \\
\hline & $\begin{array}{l}\text { Coburn through Loysburg, } \\
\text { Undivided } \\
\text { Ocl }\end{array}$ & $\begin{array}{l}\text { Coburn: Medium and medium- to very dark- } \\
\text { gray thin-bedded, argillaceous, and } \\
\text { fossiliferous limestone containing interbeds } \\
\text { of calcareous shale. }\end{array}$ & 325 & $\begin{array}{l}\text { Coburn through Loysburg } \\
\text { aquifers } \\
\text { (mixed limestone/dolomite) }\end{array}$ \\
\hline & & $\begin{array}{l}\text { Salona: very dark-gray to black, medium- to } \\
\text { coarse-grained, sparsely fossiliferous } \\
\text { limestone with some shale partings. }\end{array}$ & 170 & \\
\hline & & $\begin{array}{l}\text { Nealmont: medium- to dark-gray, coarsely } \\
\text { crystalline, limestone and medium- to dark- } \\
\text { gray, finely crystalline limestone. }\end{array}$ & $30-75$ & \\
\hline & & $\begin{array}{l}\text { Benner: light- to dark-gray, mostly fissile to } \\
\text { flaggy and thick-bedded, very-finely to finely } \\
\text { crystalline limestone. }\end{array}$ & 150 & \\
\hline & & $\begin{array}{l}\text { Snyder: Medium- to dark-gray coarsely- } \\
\text { crystalline limestone and limestone } \\
\text { conglomerate containing interbeds of finely } \\
\text { crystalline dolomitic limestone. }\end{array}$ & 80 & \\
\hline & & $\begin{array}{l}\text { Hatter: Medium- to dark-gray fine-grained, } \\
\text { argillaceous, laminated, dolomitic and oolitic } \\
\text { limestone. }\end{array}$ & 75 & \\
\hline & & $\begin{array}{l}\text { Loysburg: Light- to medium-gray medium- to } \\
\text { thick-bedded, fine-grained, shaly limestone } \\
\text { and dark gray dolomite and dolomitic } \\
\text { limestone. }\end{array}$ & 150 & \\
\hline & $\begin{array}{l}\text { Bellefonte and Axemann, } \\
\text { Undivided } \\
\text { Oba }\end{array}$ & $\begin{array}{l}\text { Bellefonte: light- to medium-gray, very fine- } \\
\text { grained dolomite and medium-gray dolomite } \\
\text { with sandstone beds and chert }\end{array}$ & 1,400 & $\begin{array}{r}\text { Bellefonte / Axemann aquifer } \\
\text { (mixed limestone dolomite) }\end{array}$ \\
\hline & & $\begin{array}{l}\text { Axemann: Light- to dark-gray, coarsely } \\
\text { crystalline, fossiliferous limestone } \\
\text { interbedded with silty, fine-grained limestone } \\
\text { and silty, fine-grained dolomitic limestone. }\end{array}$ & $400-700$ & \\
\hline
\end{tabular}




\section{Determining Sources of Water and Contaminants to Wells in a Carbonate Aquifer near Martinsburg, Pennsylvania}

Table 1. Geologic-stratigraphic and hydrologic units column near Martinsburg, Blair County, Pennsylvania.—Continued [Descriptions from Becher, 1996]

\begin{tabular}{|c|c|c|c|c|}
\hline $\begin{array}{l}\text { Geologic } \\
\text { age }\end{array}$ & $\begin{array}{l}\text { Geologic formation } \\
\text { and abbreviation } \\
\text { (units as mapped locally) }\end{array}$ & Geologic description & $\begin{array}{l}\text { Thickness } \\
\text { (feet) }\end{array}$ & $\begin{array}{l}\text { Hydrologic unit } \\
\text { (lithology) }\end{array}$ \\
\hline \multirow[t]{2}{*}{$\begin{array}{l}\text { Ordovician } \\
\qquad \text { (continued) }\end{array}$} & $\begin{array}{l}\text { Nittany and Stonehenge, } \\
\text { Undivided } \\
\text { Ons }\end{array}$ & $\begin{array}{l}\text { Nittany: Finely to coarsely crystalline, } \\
\text { alternating light- and dark-gray beds of } \\
\text { dolomite that contains siliceous oolites and } \\
\text { some sandy and cherty beds. }\end{array}$ & 1,200 & $\begin{array}{l}\text { Nittany / Stonehenge aquifer } \\
\text { (mixed limestone / dolomite) }\end{array}$ \\
\hline & & $\begin{array}{l}\text { Stonehenge: Medium and dark-gray, finely } \\
\text { crystalline limestone that contains thin } \\
\text { laminae, bands, or as much as 6-foot thick } \\
\text { interbeds of dolomite. }\end{array}$ & $250-600$ & \\
\hline \multirow[t]{2}{*}{ Cambrian } & $\begin{array}{l}\text { Gatesburg } \\
\quad € g\end{array}$ & $\begin{array}{l}\text { Dark-gray, coarse-grained dolomite. Dark- } \\
\text { gray, thin bedded, microcrystalline, silty } \\
\text { dolomite; finely crystalline, shaly dolomite, } \\
\text { and coarse-grained quartzose sandstone beds } \\
\text { grading from conglomerate to sandstone. } \\
\text { Interbedded limestone and sandstone. } \\
\text { Massively bedded, coarsely crystalline } \\
\text { dolomite. Dark-gray medium and coarsely } \\
\text { crystalline dolomite interbedded with oolitic } \\
\text { and cryptozoan-bearing dolomite. }\end{array}$ & $1,980-2,160$ & Gatesburg aquifer (dolomite) \\
\hline & $\begin{array}{l}\text { Waynesboro }{ }^{1} \\
\text { Ewb }\end{array}$ & $\begin{array}{l}\text { Greenish-gray and grayish-purple shale } \\
\text { interbedded with greenish-gray sandstone } \\
\text { and conglomerate. }\end{array}$ & $1,000-1,500$ & $\begin{array}{l}\text { Reedsville and Waynesboro } \\
\text { aquifer (shale) }\end{array}$ \\
\hline
\end{tabular}

\footnotetext{
${ }^{1}$ Geologic description from Taylor and others, 1982.
}

Table 2. Hydrogeologic properties of aquifers in the study area (from Becher, 1996).

[Intended use of well: H, High capacity; L, Low capacity; (gal/min)/ft, gallons per minute per foot of drawdown; --, no data]

\begin{tabular}{|c|c|c|c|c|}
\hline Aquifer name & $\begin{array}{c}\text { Median reported } \\
\text { yield } \\
\text { (gallons per minute) }\end{array}$ & $\begin{array}{c}\text { Specific capacity } \\
{[(\mathrm{gal} / \mathrm{min}) / \mathrm{ft}]-24 \text { hour test }}\end{array}$ & $\begin{array}{c}\text { Transmissivity } \\
\text { (feet squared per day) }\end{array}$ & $\begin{array}{c}\text { Average well depth } \\
\text { (feet) }\end{array}$ \\
\hline Bellefonte and Axemann & $10(\mathrm{~L})$ & $.18(\mathrm{~L})$ & ${ }^{1} 40$ & 180 \\
\hline Nittany Stonehenge & $11(\mathrm{~L})$ & $.19(\mathrm{~L})$ & ${ }^{1} 40$ & 175 \\
\hline Reedsville & $20(\mathrm{~L})$ & $.4(\mathrm{~L})$ & -- & -- \\
\hline
\end{tabular}

\footnotetext{
${ }^{1}$ Based on median specific-capacity data.
}

${ }^{2}$ Based on aquifer-test data at well field. 


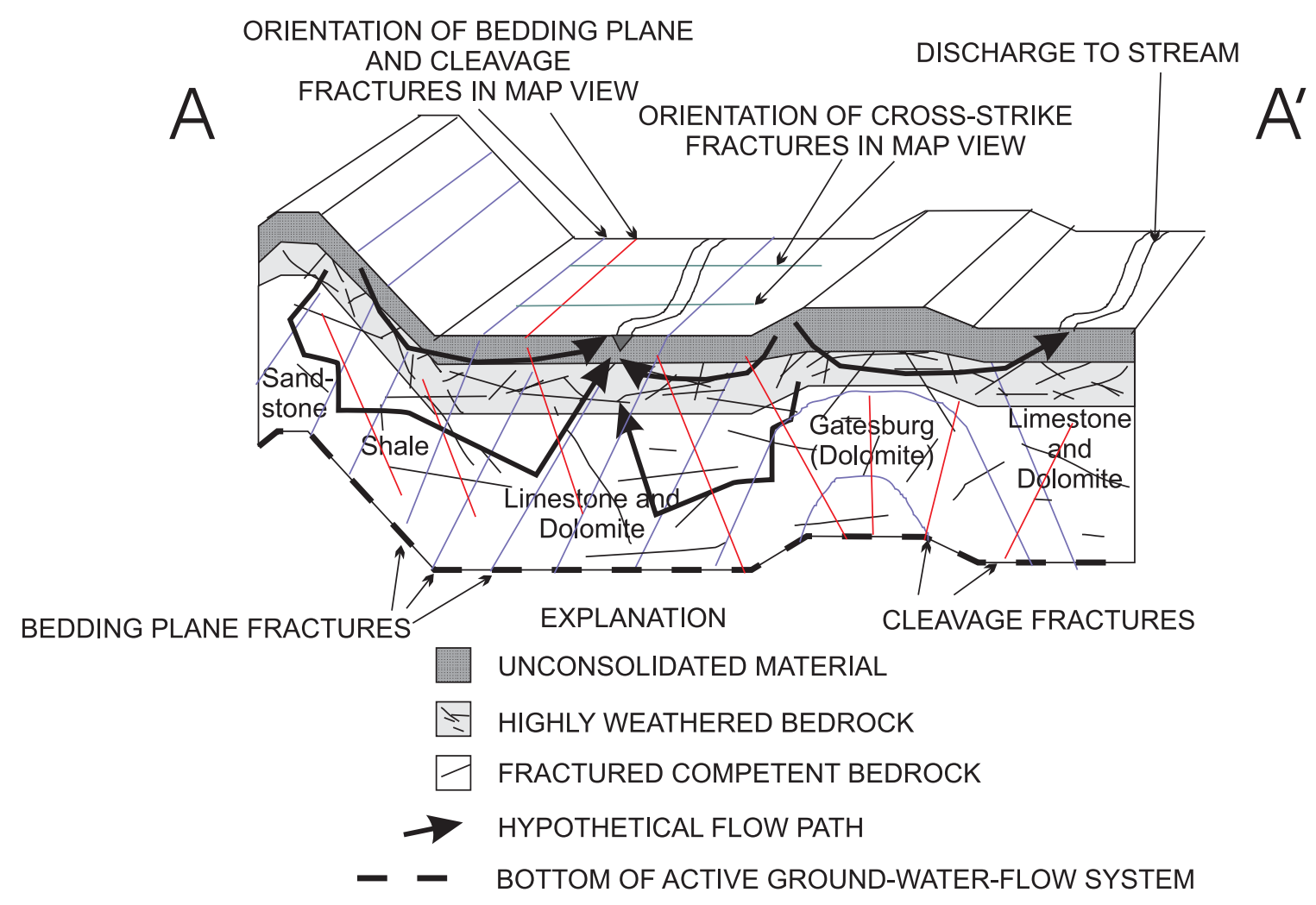

Figure 5. Conceptual model of ground-water-flow system near Martinsburg, Pennsylvania. Generalized hydrogeologic section near A - A' from figure 3.

That part of the aquifer system between the land surface and competent bedrock is unconsolidated (fig. 5). Water in this part of the ground-water system travels through voids between individual grains of material. The differences in hydrologic properties of the unconsolidated material vary on the basis of the properties of the parent material (fig. 6). In the case of soils on mountain slopes, the unconsolidated material overlying a given geologic formation may be material transported downslope from other geologic formations; however, for the majority of the study area, the unconsolidated material is residuum from weathering of the underlying bedrock formation. Soils overlying sandstone lithology include silt loam, but also have soils with a higher sand content such as loam and sandy loam as well as loose stones or rubble (fig. 6). Major soil types overlying shale lithologies include loam, silt loam, and clay loam. Soil types overlying the mixed limestone and dolomite lithologies are predominantly silt loam. Other soils that overlie these mixed limestone and dolomites are near the boundaries with other rock types and appear to have been transported downslope from their location of origin. The soils overlying the Gatesburg aquifer are classified as sand or sandy loam. Becher (1996) also has noted that the unconsolidated material overlying the Gatesburg aqui- fer consists of a thick sandy residuum. The upper portion of the unconsolidated material is typically above the water table; however, some of the unconsolidated material can be saturated. Those parts of the unconsolidated material that are saturated are part of the aquifer system. The thickness of the unconsolidated material overlying the other carbonate rocks in this study is highly variable. The boundary between the unconsolidated material and the highly weathered bedrock is not well defined, and the highly weathered part of the aquifer may maintain some of the structural orientation of the original bedrock.

The bedrock has three potential types of permeability to water-primary, fractures, and conduits. Primary permeability could occur in interconnected spaces between grains; however, in the study area, primary permeability is not considered to be a major factor affecting ground-water flow. Water that travels through fractures generally moves slowly (in the range of tens of feet per day or less). Fractures enlarged by chemical dissolution can become conduits. Water that travels through large solution conduits moves rapidly (in the range of hundreds of feet per day or more). The flow regime in conduits becomes turbulent, as opposed to laminar flow regimes in unconsolidated materials and fracture flow (White, 1988). 


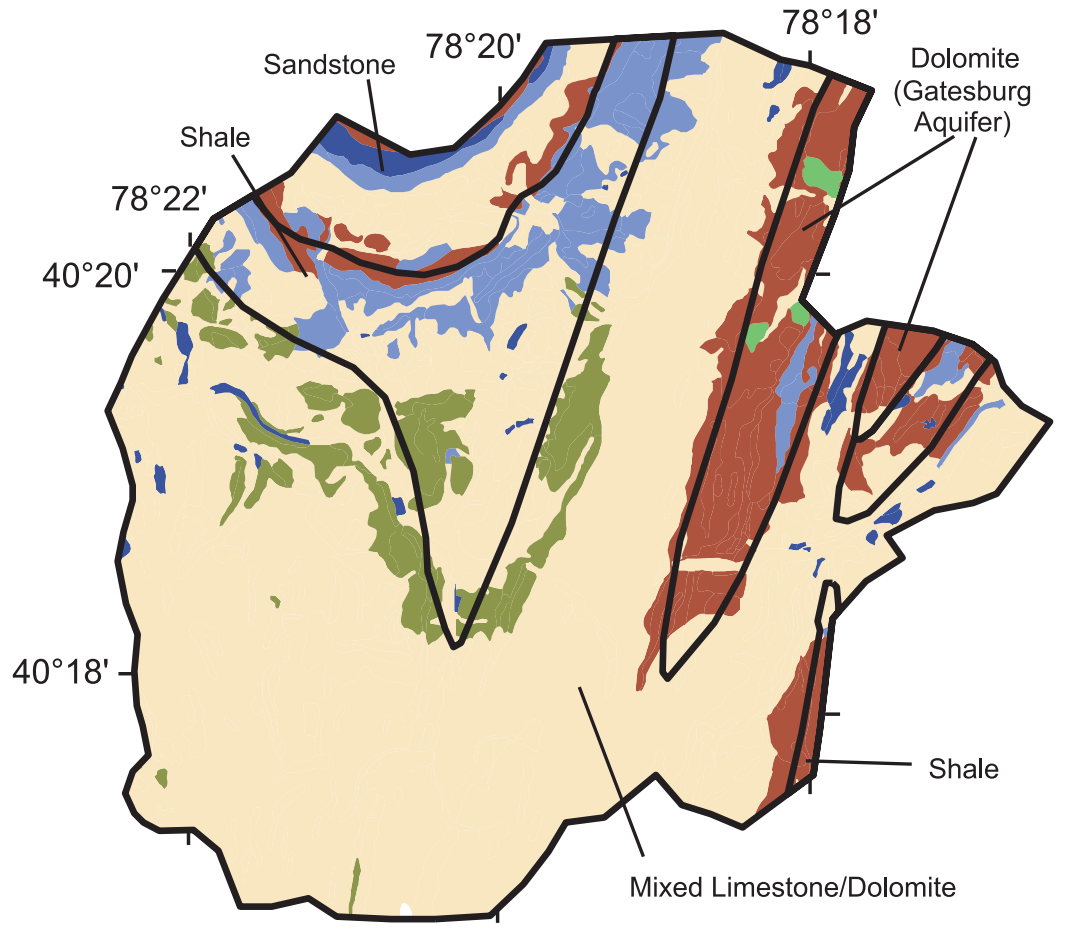

EXPLANATION

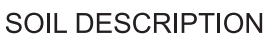

$\begin{array}{ll}\text { Clay Loam } & \text { Sand } \\ \text { Loam } & \text { Sandy Loam } \\ \text { Other (water, rock) } & \text { Silt Loam }\end{array}$

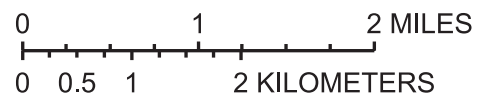

The fracture patterns in the Martinsburg area were not determined from field measurements, but the probable patterns can be deduced because they typically form along weaknesses in the rock caused by initial sedimentary structures in the rock and the tectonic forces that deformed the rocks. These fractures may be related to bedding and cleavage (both parallel to the strike of the axial fold in map view) or they may be perpendicular to the strike of the axial fold (fig. 7). Bedding planes were identified by Butts (1945); the orientation of cleavage and cross-strike fractures have been inferred from the orientation of bedding planes. Bedding is a depositional structure in sedimentary rocks that would have been planar and horizontal at the time of deposition. During tectonic deformation, weaknesses between bedding planes may have been enhanced as beds slipped along each other to accommodate the deformation. Dip directions of bedding vary due to folding, but the strike in the vicinity of the Martinsburg wells is N. $30^{\circ}$ E., parallel to the fold axis (Butts, 1945). Axial cleavage fractures are created as a result of the stress during deformation and create a fan pattern over the axis of a fold in geologic section (fig. 7). Cleavage is nearly perpendicular to bedding and varies with the dip of the beds. Cleavage also is parallel to the fold axis; therefore, bedding and cleavage planes intersect in lines parallel to the fold
Figure 6. Basic soil types (color coded) and their relation to bedrock lithology (labeled) near Martinsburg, Pennsylvania. Soil data from U.S. Department of Agriculture (1981); geology from Berg (1980).

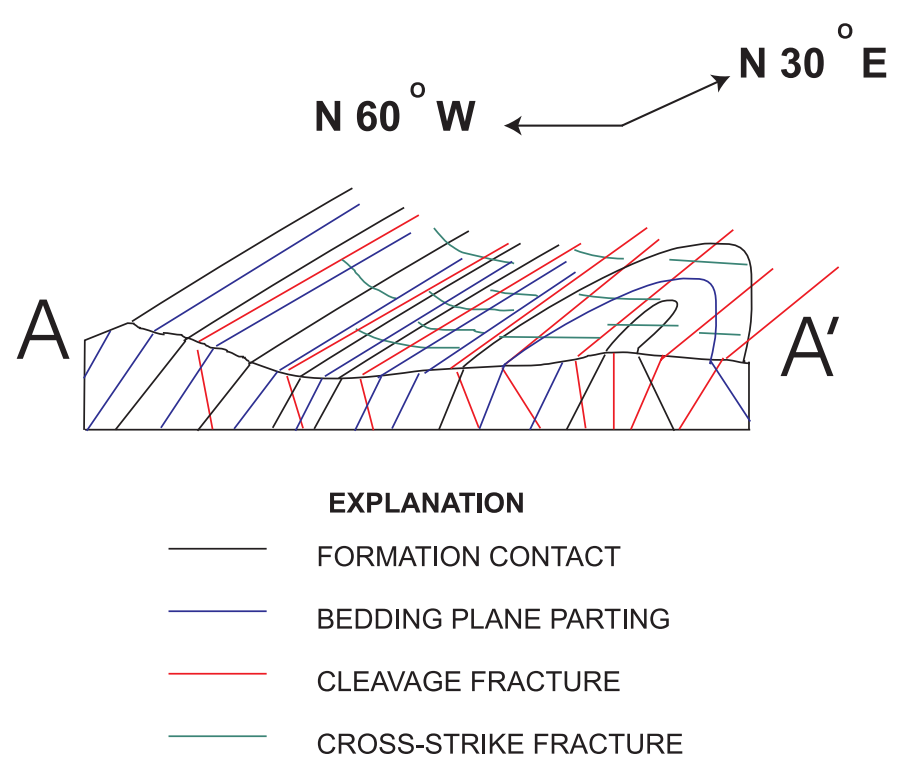

(Trace of section is shown in figure 3 )

Figure 7. Conceptual model of hypothetical orientation of major fracture sets in study area near Martinsburg, Pennsylvania. 
axis. Tectonic stresses also have been shown to create near-vertical fractures in the direction of the compressional force perpendicular to the fold. In this case, such fractures (cross-strike fractures-fig. 7) would be oriented perpendicular to the fold axis or $\mathrm{N} .60^{\circ} \mathrm{W}$.

Typically, not all fracture sets have the same capacity to transmit water; thus understanding the orientation of the dominant water-bearing fractures may be helpful for predicting ground-water-flow directions. Bedding-plane partings were found by Burton and others (2002) to be the dominant pathway of ground-water flow in a fractured-bedrock aquifer imparting anisotropy (hydraulic conductivity is not the same in every direction) in the ground-water-flow system. Conduits can develop along existing fractures; therefore, the orientation of conduits is likely to be similar to that of the dominant fracture set. Because of the preferred orientation of fractures and conduits, carbonate aquifers are likely to be anisotropic (White, 1988). Although the abundance of each of these fracture sets and their importance in the local flow system near Martinsburg is unknown, the orientation of the fractures sets deduced from bedding and structure can be used in determining the orientation of the ground-water model as well as developing the conceptual model of the ground-water flow.

A major geologic factor that can have an appreciable effect on ground-water flow in this area is the presence of karst features such as sinkholes, closed depressions, vertical shafts, caves, and conduits. Surface water can enter sinkholes directly, allowing contaminants to enter the aquifer that may have otherwise been attenuated in the soil. Closed depressions are topographically low areas where water can accumulate during wet periods. Closed depressions can have vertical dissolutional features called shafts that drain the accumulated water. Caves are naturally occurring openings in the subsurface large enough for human entry. Although caves can be related to ground-water flow, a more relevant feature would be a conduit or a subsurface fissure or tunnel that is filled with water.

Some of these karst features in the Martinsburg area were mapped by the Pennsylvania Topographic and Geologic Survey (William Kochanov, Pennsylvania Topographic and Geologic Survey, written commun., 2002) and are shown on figure 8 . The orientation of caves was used to infer possible preferential flow directions of ground water. Three caves have been identified in the study area (Speece and Cullinan, 1972) (fig. 8). The cave approximately $0.5 \mathrm{mi}$ south of Martinsburg is Martinsburg Cave, classified as a small cave with branches trending due north and due east with a total length of $85 \mathrm{ft}$. Most of the cave has collapsed, forming numerous sinkholes that have since been filled. The other two caves are a pair known as Drake Cave \#1 and Drake Cave \#2 (Speece and Cullinan, 1972) and are approximately $1 \mathrm{mi}$ west of Martinsburg. Drake Cave \#1 is about $25 \mathrm{ft}$ long trending north-south and ending in a blockage of rock. Drake Cave \#2 is about $300 \mathrm{ft}$ to the east of Drake Cave $\# 1$ and trends northwest-southeast. It also is about $25 \mathrm{ft}$ long and pinches out at the end. All three caves are above the water table. It is interesting to note that the trends of the cave passages are approximately aligned with the bedding (Drake Cave \#2 and Martinsburg Cave), cleavage (Drake Cave \#1), or cross-strike fractures (Martinsburg Cave) (fig. 8); however, this small number of caves does not provide sufficient evidence to draw conclusions about whether or not caves or conduits would always be oriented in these directions. Conduits probably are the most difficult feature to identify because they have no easily identified expression on the land surface; however, areas with a high density of the other karst features may have a higher probability of having conduits. The non-uniform density of karst features on figure 8 could be related to geologic structure (intersection of major fracture sets) or differences in lithology.

The Nittany/Stonehenge Formation appears to have a higher density of karst features than other formations in figure 8 , which may lead to the conclusion that lithology is the key to development of karst features. Lithology alone, however, does not explain the relative density of karst features. In the southwestern part of the ground-water model area, the density of karst features in the Bellefonte/Axemann Formation is similar to that found in the Nittany/Stonehenge Formation; however, in the central part of the ground-water model area, karst features are not present in the Bellefonte/Axemann Formation. The orientation and density of the major fracture sets (fig. 7) may vary on the basis of their position relative to the fold axis. Stress during folding events may have been more intense in some areas than in other areas based on their positions along the fold; fracture sets in those areas may allow preferential development of karst features.

In some karst areas, point recharge is significant. Entire streams can disappear into sinkholes and be a major component of recharge. Despite numerous karst features in this area, this type of recharge was not considered to be an important component of recharge because the model area is located at headwaters where no regional stream brings in flow from outside of this area. Also, measurement of stream discharge at successive points along streams exhibited no areas where these local streams were losing water to the aquifer. Although the sinkholes and closed depressions probably direct water into the aquifer in concentrated zones from vertical pipes or shafts in the bedrock, this water is from precipitation in the immediate area near that sinkhole or closed depression. Therefore, recharge was considered to be areally distributed.

The topographic position of the well fields is an important factor in determining the boundaries for the study area. The well fields are near the headwaters of three stream drainages:

1) Cove Creek to the west, 2) Piney Creek to the north, and 3) an unnamed tributary to Clover Creek to the east (fig. 4). The boundary of the study area includes the surface drainage basins of these three watersheds to allow the model to simulate the configuration of the water table near the watershed divide. The study by Becher (1996) produced a water-table map for the area that includes most of the current study area. Becher's watertable map indicated the water table was smooth and generally followed the land-surface contours (fig. 9). 

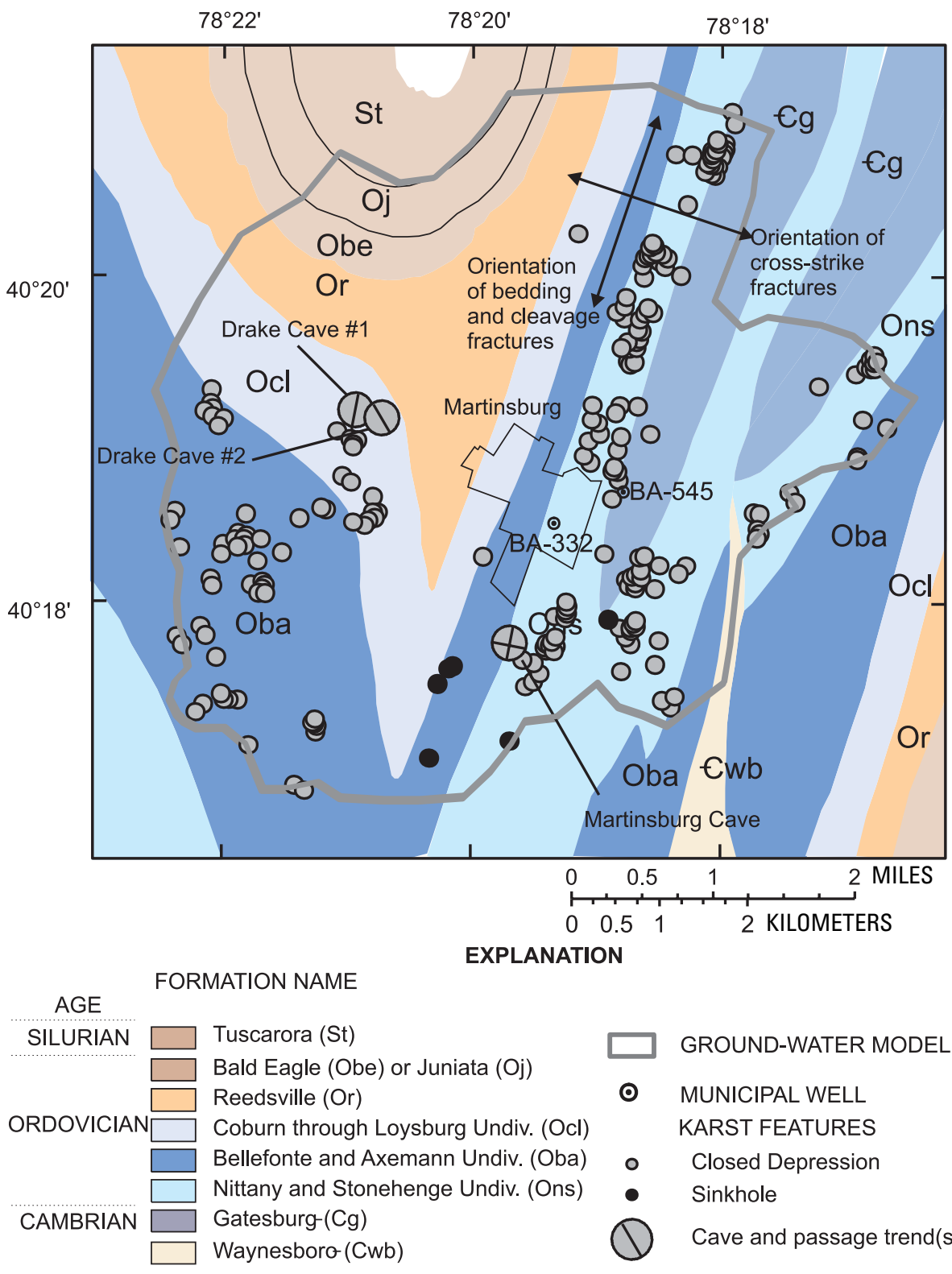

GROUND-WATER MODEL BOUNDARY

- MUNICIPAL WELL KARST FEATURES

Closed Depression

Sinkhole

Cave and passage trend(s)
Figure 8. Karst features within ground-water model boundary near Martinsburg, Pennsylvania. (Cave locations, Speece and Cullinan (1972); Sinkhole and closed depression data from William Kochanov, Pennsylvania Topographic and Geologic Survey, written commun., 2002).

\section{Well-Field Characteristics}

Martinsburg Borough uses four wells for municipal supply. The well known as the Hershberger Well (USGS well number BA 332) is in the borough, referred to as the Hershberger well field, and the other three wells (Well \#1, BA 329; Well \#2, BA 330; and Well \#3, BA 545) are to the east of the borough in the Wineland Well field (fig. 3). Well BA 332 is completed in the Nittany/Stonehenge aquifer and is $100 \mathrm{ft}$ deep with approximately $80 \mathrm{ft}$ of 12 -in. casing; static water levels are typically about $12 \mathrm{ft}$ below land surface. Wells BA 545, BA 329, and BA 330 are completed in the Gatesburg aquifer. BA 329 is $255 \mathrm{ft}$ deep with $134 \mathrm{ft}$ of 6-in. casing; static water levels are typically about $80 \mathrm{ft}$ below land surface. BA 330 is $224 \mathrm{ft}$ deep with $195 \mathrm{ft}$ of 6-in. casing; static water levels are typically about $80 \mathrm{ft}$ below land surface. BA 545 is $308 \mathrm{ft}$ deep with $235 \mathrm{ft}$ of 8 -in. casing. Static water levels in well BA 545 range from 85 to $95 \mathrm{ft}$ below land surface (Randy Stoltz, Martinsburg Municipal Authority, written commun., 2002). All four wells draw water from the open borehole between the bottom of the casing and 


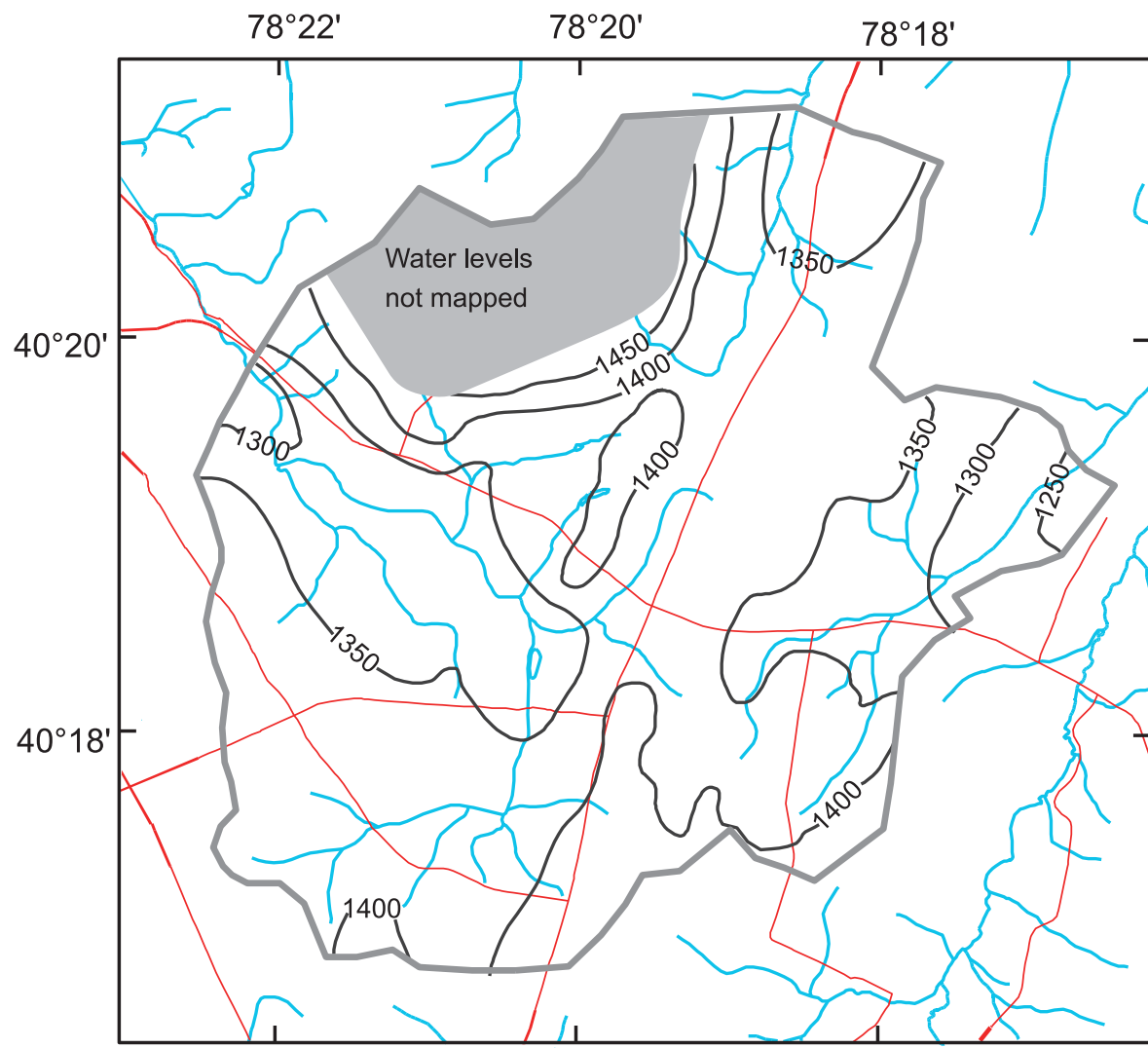

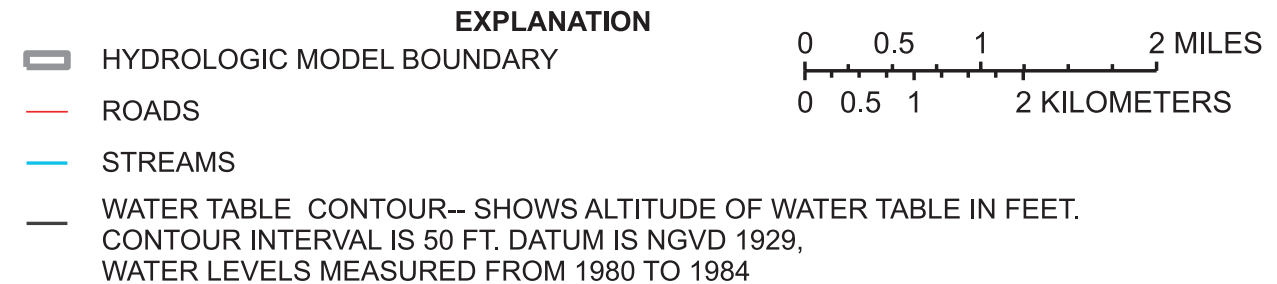

Figure 9. Water levels near Martinsburg, Pennsylvania (Based on Becher, 1996, plate 2).

the bottom of the well. Driller's logs from well BA 545 indicate an interval of medium-grained sand from below the soil layer to approximately $90 \mathrm{ft}$ and that the well was completed in competent bedrock without encountering voids in the open interval (Crystal Newcomer, Moody and Associates, written commun., 1986). The wells are pumped on alternate days. Well BA 332 is pumped at a rate of $300,000 \mathrm{gal} / \mathrm{d}$ on 1 day. BA 545 and BA 329 are pumped on the alternate day at rates of 210,000 and $90,000 \mathrm{gal} / \mathrm{d}$, respectively, to supply the daily requirement of $300,000 \mathrm{gal} / \mathrm{d}$. BA 330 currently (2003) is not used. 


\section{Determining Sources of Water and Contaminants to Wells in a Carbonate Aquifer near Martinsburg, Pennsylvania}

\section{Land Use and Sources of Nitrogen}

Potential sources of ground-water contaminants are related to the land use. General classifications of land use in the study area are shown in figure 10. The areas within the ground-water model boundary shown in figure 10 include 1 ) forested areas with virtually no source of nitrogen other than precipitation, 2) agricultural areas with manure (either applied to fields or as runoff from pastures and feedlots) and chemical fertilizers as potential sources of nitrogen, and 3) low-density residential (urban) with potential nitrogen sources from sewage and fertilizers. In areas served by public sewers, leaking sewer lines may be a source of nitrogen to the ground water. Residences not served by public sewer lines have on-lot septic systems for sewage disposal. In areas with on-lot septic systems, nitrogen may leach into the ground water directly from the systems. The areas served by public sewer lines are shown in figure 11 . Homeowners in residential areas may use lawn fertilizers, which are a potential source of nitrogen as well. A summary of the land use in the area around Martinsburg used for the simulation of ground-water flow is shown in table 3.

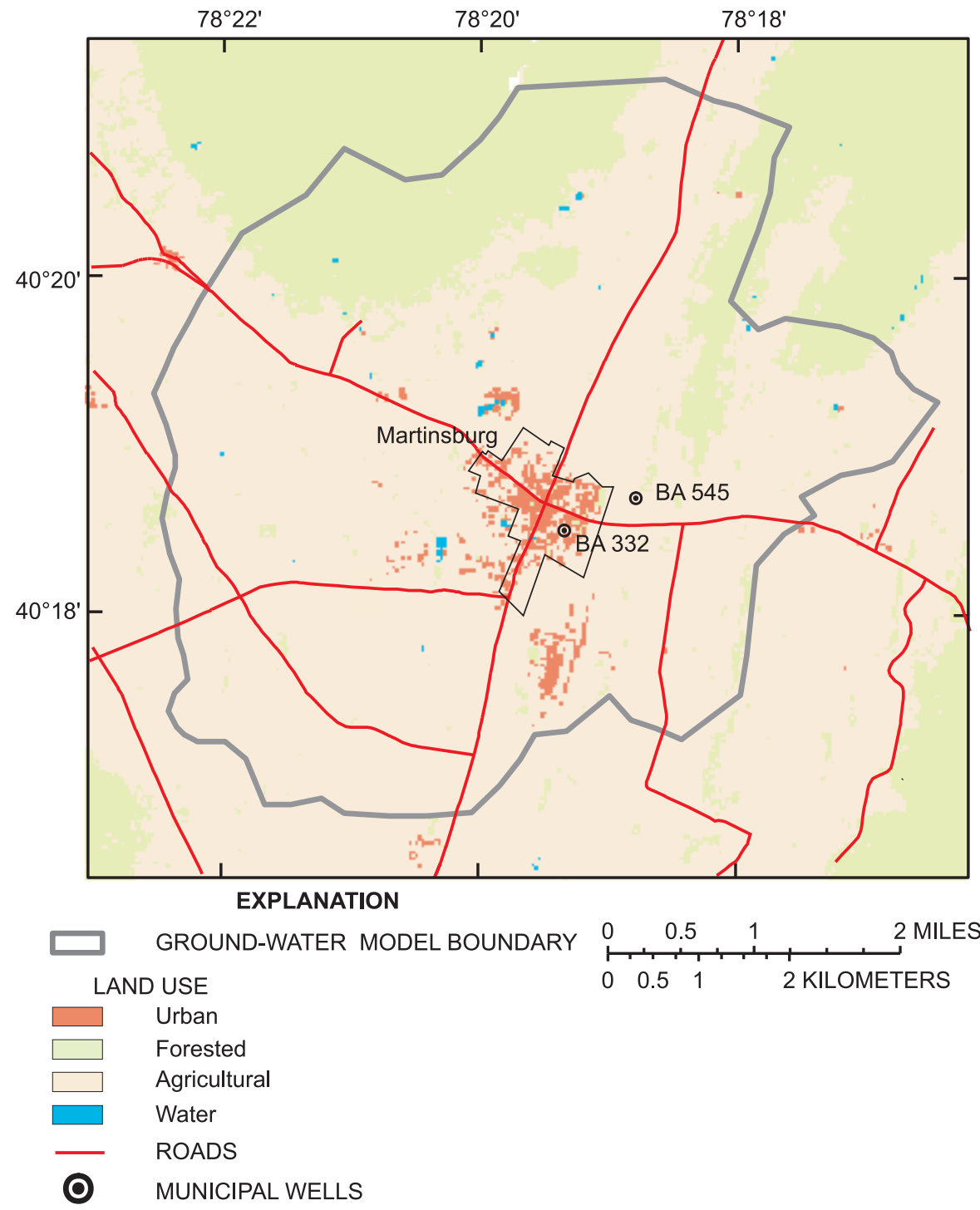

Figure 10. Generalized land use in the area of Martinsburg, Pennsylvania (Vogelman and others, 1998a, 1998b). 


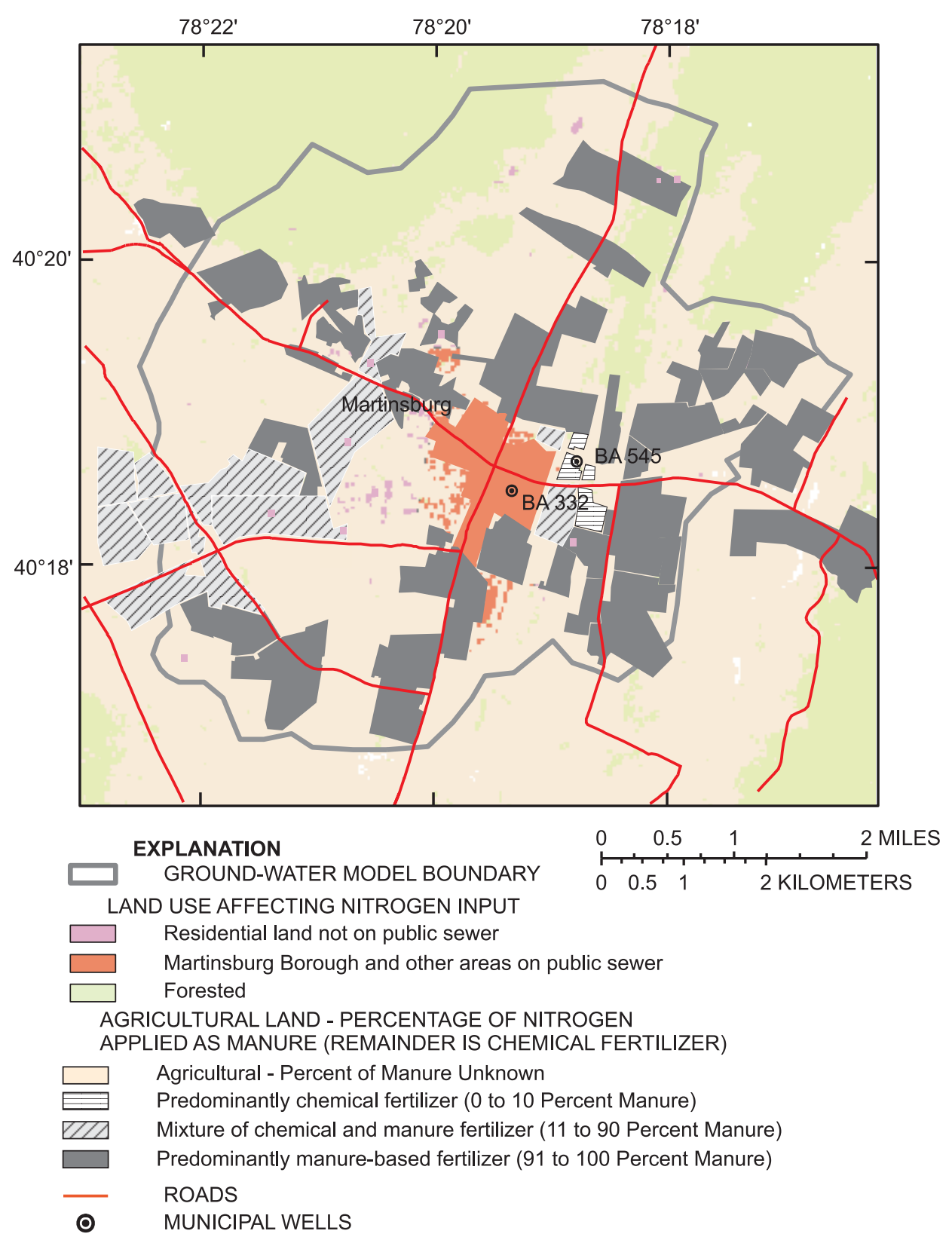

Figure 11. Types of nitrogen applied to fields and areas served by public sewer lines near Martinsburg, Pennsylvania (Manure and fertilizer application from Amanda Ritchy, Blair County Conservation District, written commun., 2003; Sewer line locations from Randy Stoltz, Martinsburg Borough, written commun., 2003).

Table 3. Land covers included in the land-use groupings in the study area near Martinsburg, Pennsylvania (Modified from Vogelman and others, 1998a, 1998b).

\begin{tabular}{llc}
\hline $\begin{array}{l}\text { Land-use grouping } \\
\text { shown on figure 10 }\end{array}$ & \multicolumn{1}{c}{ Land cover } & $\begin{array}{c}\text { Percentage } \\
\text { of area }\end{array}$ \\
\hline Agricultural & Row crop & 61.6 \\
& Hay pasture & 18.6 \\
\hline Forested & Deciduous forest & 15.4 \\
& Mixed forest & 1.6 \\
& Evergreen forest & .2 \\
& Emergent herbaceous wetland & .1 \\
\hline Urban & High-intensity commercial & .5 \\
& High-intensity development & .4 \\
& Low-intensity residential & 1.6 \\
\hline Water & Water & .2 \\
\hline
\end{tabular}




\section{Study Methods}

The description of study methods includes those techniques used in the field for collection of data, the methods used in laboratories to analyze the data, and the methods used to interpret the data.

\section{Field Data Collection and Analytical Methods}

Field data were collected to provide streamflow and ground-water levels needed for delineating the areal extent of the zone of contribution to the Martinsburg municipal wells by use of a numerical ground-water-flow model. Water-quality data also were collected to determine the source of contaminants in the municipal wells. Data were collected at eight pri- vate homeowner wells, two municipal wells, one spring used for domestic supply, and four streams draining the area around Martinsburg, Pa. Water-quality samples were collected and water levels were measured in September 2002; water levels and streamflow were measured in November 2002 (fig. 12, table 4). Water levels from 11 additional wells were obtained from the USGS Ground Water Site Inventory database for use in model calibration (table 4).

The field data collected at the 10 wells and the spring consisted of volumetric measurements of discharge, site characteristics, and water levels (wells only). Samples of untreated rawwater also were collected at selected sites. The data were collected according to USGS protocols (U.S. Geological Survey, 1997 to present). For the wells with removable well caps, the water level was measured using an electric tape cleaned with

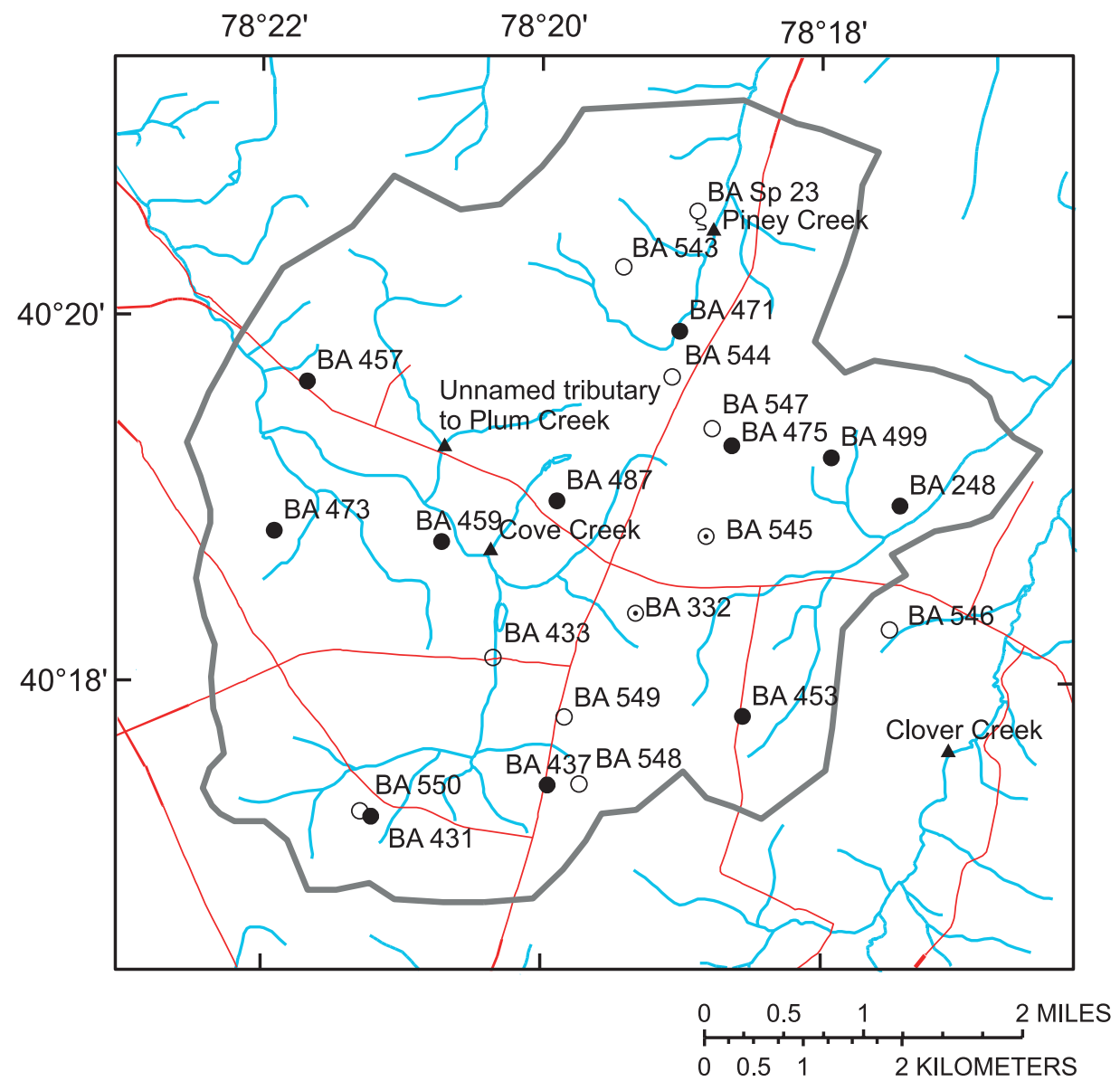

EXPLANATION

GROUND-WATER MODEL BOUNDARY

- ROADS

- STREAMS
SAMPLE POINT TYPE

\ STREAM

BA $332 \odot \quad$ MUNICIPAL WELL AND NUMBER (TABLE 4)

BASp $23 \quad$ SPRING AND NUMBER (TABLE 4)

BA $548 \bigcirc$ WELL SAMPLED AND NUMBER (TABLE 4)

BA 431 WELL- WATER LEVEL ONLY AND NUMBER (TABLE 4)
Figure 12. Location of wells, springs, and streams sampled or measured in and near Martinsburg, Pennsylvania. 
Table 4. Wells sampled and/or used for model calibration near Martinsburg, Pennsylvania.

[ft, feet; n/a, not applicable; --, no data; NAD 83, North American Datum of 1983; NGVD 29, National Geodetic Vertical Datum of 1929]

\begin{tabular}{|c|c|c|c|c|c|c|c|c|c|}
\hline $\begin{array}{l}\text { County well } \\
\text { or spring } \\
\text { number }\end{array}$ & Aquifer & $\begin{array}{l}\text { Latitude } \\
\text { (degrees, } \\
\text { minutes, } \\
\text { seconds, } \\
\text { NAD 83) }\end{array}$ & $\begin{array}{l}\text { Longitude } \\
\text { (degrees, } \\
\text { minutes, } \\
\text { seconds, } \\
\text { NAD 83) }\end{array}$ & $\begin{array}{c}\text { Elevation of } \\
\text { land surface } \\
\text { (ft above } \\
\text { NGVD 29) }\end{array}$ & $\begin{array}{c}\text { Well } \\
\text { depth } \\
\text { (ft) }\end{array}$ & $\begin{array}{l}\text { Casing } \\
\text { length } \\
\text { (ft) }\end{array}$ & $\begin{array}{l}\text { Water } \\
\text { level } \\
\text { below land } \\
\text { surface } \\
\text { (ft) }\end{array}$ & $\begin{array}{l}\text { Model } \\
\text { layer }\end{array}$ & $\begin{array}{c}\text { Date of } \\
\text { water level }\end{array}$ \\
\hline BA $248^{1}$ & Nittany/ Stonehenge & 401857 & 781730 & 1,334 & 145 & 60 & 58 & 2 & $05 / 01 / 1980$ \\
\hline BA $332^{2,3}$ & Nittany/ Stonehenge & -- & -- & 1,393 & 100 & -- & 30 & 2 & 09/10/2002 \\
\hline $\mathrm{BA} 43^{1}$ & Bellefonte/ Axemann & 401711 & 782119 & 1,445 & 325 & 21 & 38 & $1-2$ & 05/01/1980 \\
\hline BA $437^{1}$ & Bellefonte/ Axemann & 401724 & 781958 & 1,439 & 105 & 21 & 15 & $1-2$ & $10 / 23 / 1984$ \\
\hline $\mathrm{BA} 453^{1}$ & Nittany/ Stonehenge & 401748 & 781833 & 1,475 & 180 & -- & 84 & $1-2$ & 05/01/1980 \\
\hline BA $457^{1}$ & Coburn through Loysburg & 401931 & 782134 & 1,361 & 325 & 37 & 35.65 & $1-2$ & 06/14/1984 \\
\hline BA $459^{1}$ & Coburn through Loysburg & 401845 & 782044 & 1,349 & 145 & 45 & 27.2 & $1-2$ & 05/15/1984 \\
\hline BA $471^{1}$ & Bellefonte/ Axemann & 401955 & 781901 & 1,409 & 60 & -- & 15 & 2 & 05/15/1984 \\
\hline BA $499^{1}$ & Nittany/ Stonehenge & 401913 & 781757 & 1,419 & 170 & 135 & 71.1 & 2 & 05/14/1984 \\
\hline BA $543^{4}$ & Reedsville & 402013.5 & 781927.2 & 1,473 & 145 & 28 & 22.9 & $1-2$ & 09/09/2002 \\
\hline BA $544^{4}$ & Bellefonte/ Axemann & 401938.6 & 781903.6 & 1,437 & 125 & 50 & 43.3 & $1-2$ & 09/09/2002 \\
\hline BA $545^{2,3}$ & Gatesburg & -- & -- & 1,405 & 308 & 90 & 113 & 2 & 09/09/2002 \\
\hline BA $546^{4}$ & Bellefonte/ Axemann & 401813.8 & 781728.4 & 1,336 & 180 & 40 & 70 & $1-2$ & $09 / 10 / 2002$ \\
\hline BA $547^{4}$ & Nittany/ Stonehenge & 401923.1 & 781848.1 & 1,473 & 200 & 50 & 138 & $1-2$ & 09/11/2002 \\
\hline BA $548^{4}$ & Nittany/ Stonehenge & 401726.5 & 781945.4 & 1,461 & 185 & 130 & 44 & 2 & $09 / 11 / 2002$ \\
\hline BA $549^{5}$ & Bellefonte/ Axemann & 401746.8 & 781951.3 & 1,449 & 420 & 21 & 32.45 & $1-2$ & $09 / 11 / 2002$ \\
\hline BA $550^{5}$ & Bellefonte/ Axemann & 401718 & 782115.5 & 1,440 & 310 & 40 & 108 & $1-2$ & $09 / 11 / 2002$ \\
\hline BA Sp $23^{5}$ & Coburn through Loysburg & 402028 & 781550 & 1,334 & $\mathrm{n} / \mathrm{a}$ & $\mathrm{n} / \mathrm{a}$ & $\mathrm{n} / \mathrm{a}$ & $\mathrm{n} / \mathrm{a}$ & 09/09/2002 \\
\hline
\end{tabular}

${ }^{1}$ Well not sampled, water level used for model calibration only.

${ }^{2}$ Municipal supply well: sampled for chemical and microbiological indicators, pumping simulated in model, water level not used for calibration.

${ }^{3}$ Water level affected by recent pumping.

${ }^{4}$ Well sampled for chemical and microbiological indicators, water level used for model calibration.

${ }^{5}$ Well or spring sampled for chemical and microbiological indicators, water level not used for model calibration.

alcohol between uses. The water then was purged (usually from an outside garden hose) for 10 to 15 minutes and field constituents (temperature, specific conductance, dissolved oxygen, and $\mathrm{pH})$ were recorded. The volumetric flow was determined by recording the amount of time needed to fill a standard 5-gal bucket. The fluctuations in measurements of field constituents tended to stabilize when the standing water in the well was purged. Stability was defined as a specific conductance change of less than $10 \mu \mathrm{S} / \mathrm{cm}$, a temperature change of less than $0.5^{\circ} \mathrm{C}$, and a pH change of less than $0.2 \mathrm{pH}$ units in a 5-minute period. Water samples were collected from a spigot at the pressure tank prior to any form of water treatment or at an outside spigot if there was no treatment system. The spring was a domestic water supply and was sampled through the homeowner's plumbing. Latex gloves were worn during sample collection to prevent contamination. The sampling requirements for each analysis are shown in table 5. The water samples were placed on ice and transported to the appropriate location for analysis.
Surface-water sites were sampled according to standard USGS procedures (U.S. Geological Survey, 1997 to present). Volumetric flow was measured at each site using a Pygmy current meter. The meter-type selection was based on stream depth and velocity. The water sample was collected as a single depthintegrated sample in the center of the stream. The bottle was lowered and raised through the water column, capped immediately, and placed on ice. Field constituents were recorded when previously defined stability criteria were met. Surface-water samples and flow measurements were intended to represent base-flow conditions. Comparison of the streamflow at the nearest USGS streamflow-measurement station on the sampling dates to annual streamflow statistics at those sites helps put the sampling conditions in perspective. Water-chemistry samples were collected on September 11, 2002. On this date, the daily mean streamflow at Frankstown Branch Juniata River (USGS station number 01556000 ) was $47 \mathrm{ft}^{3} / \mathrm{s}$, which is a flow exceeded 90 percent of the time during the entire period of record (1916 to 2003) and is representative of very low base flow. Streamflow was measured on November 20, 2002. On 


\section{Determining Sources of Water and Contaminants to Wells in a Carbonate Aquifer near Martinsburg, Pennsylvania}

Table 5. Sampling requirements and analytical methods for water analyses from wells and streams near Martinsburg, Pennsylvania.

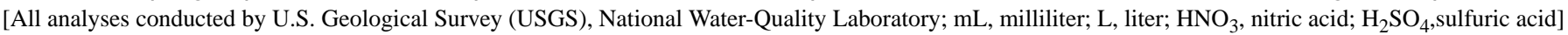

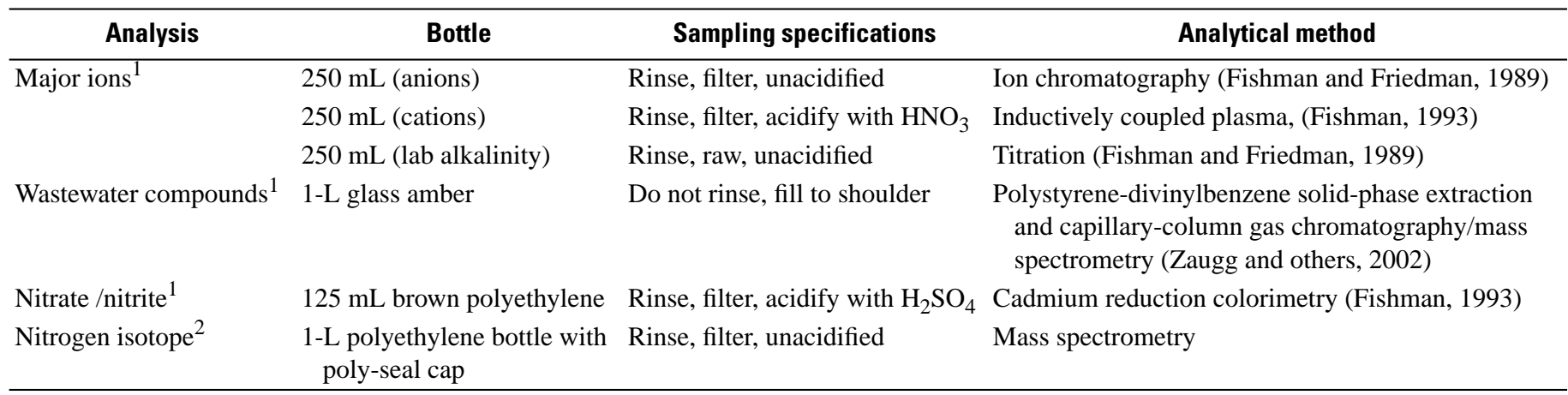

${ }^{1}$ Analyzed by USGS National Water-Quality Laboratory, Denver, Colo.

${ }^{2}$ Analyzed by Zymax Laboratory, San Luis Obispo, Calif., on contract with USGS National Water-Quality Laboratory.

this date, the daily mean streamflow at Frankstown Branch Juniata River was $527 \mathrm{ft}^{3} / \mathrm{s}$, which is a flow exceeded 25 percent of the time and probably is representative of high base-flow discharge.

The water samples were analyzed for a variety of chemicals useful in determining the potential sources of contaminants in the aquifer and streams. The analyses included major ions, nutrients, ${ }^{15} \mathrm{~N} /{ }^{14} \mathrm{~N}$ isotope ratio (hereafter referred to as $\delta^{15} \mathrm{~N}$ ), wastewater compounds, and bacteria. Quality-assurance sampling was limited to replicate samples for nitrate, the major contaminant of concern; blanks were not collected for any sample types. Replicate samples for nitrate analysis indicated good precision in determination of nitrate concentrations. Bacteria samples underwent additional analysis for source tracking at the Pennsylvania State University, Environmental Microbiology Laboratory at the Capitol Campus, Harrisburg, Pa. (Dr. Katharine Baker, Pennsylvania State University, written commun., 2003).

\section{Methods to Determine Sources of Contaminants to Ground-Water Wells}

Multiple methods were used in this study to determine the potential sources of contaminants to the Martinsburg municipal-supply wells. First, the geochemistry of water was analyzed to determine spatial patterns of naturally occurring chemicals in ground water and evolution of geochemical constituents relative to rock formations. Second, anthropogenic contaminants were analyzed to determine their spatial distribution in ground water and their relation to surface processes. A component of the study of anthropogenic contaminants included tracking sources of bacteria detected in ground water. Finally, a groundwater model was used to determine probable directions of ground-water flow and the areal extent of the zones of contribution to wells.

\section{Natural Geochemistry of Water}

The analysis of the geochemistry of ground water was based primarily on physical properties and major-ion chemistry. The major-ion analysis is an important step in determining the water type and can help indicate sources of ground water. Some specific calculations were made on the basis of previous studies of natural ground-water geochemistry in carbonate aquifers (Langmuir and White, 1971). That study used chemical indicators, such as calcite saturation, calcium-magnesium $\left(\mathrm{Ca}^{2+} / \mathrm{Mg}^{2+}\right)$ ratios, $\mathrm{CO}_{2}$ partial pressure, and seasonal $\mathrm{pH}$ variations, to determine major sources of water (table 6 ) and types of permeability (table 7) in the nearby Nittany Valley carbonate aquifers in Center County, Pa. (fig. 1). The samples in the Langmuir and White study (1971) included water from wells in the Gatesburg, Nittany, Stonehenge, and Axemann aquifers, all of which are present in the Martinsburg area. The $\mathrm{Ca}^{2+} / \mathrm{Mg}^{2+}$ ratio is related to the type of bedrock in which the water originated. Water drawn from a pure limestone aquifer will have little or no magnesium, and water drawn from a pure dolomite aquifer will have a $\mathrm{Ca}^{2+} / \mathrm{Mg}^{2+}$ ratio of 1 . Limestone commonly contains some magnesium, and water drawn from limestone aquifers will have $\mathrm{a} \mathrm{Ca}^{2+} / \mathrm{Mg}^{2+}$ ratio near 6 with a range from 2 to 10 (White, 1988).

The partial pressure of $\mathrm{CO}_{2}$ in water is related to the connection of the ground water with the atmosphere and can be an indicator of potential for conduit flow. Partial pressure of $\mathrm{CO}_{2}$ $\left(\mathrm{PCO}_{2}\right)$ depends on whether the system is open to atmospheric air (open system) or isolated from the atmosphere (closed system) as well as the amount of soil organic matter and mixing of water from various sources. Although numerous factors affect $\mathrm{CO}_{2}$ concentrations in water, data from karst aquifers in the North Central Appalachian Mountains show that water discharged from diffuse springs and wells has $\mathrm{CO}_{2}$ partial pressures $\left(\mathrm{PCO}_{2}\right.$ water $/ \mathrm{PCO}_{2}$ atmosphere $=20$ and 33, respectively $)$ that are higher than water discharged from conduit springs $\left(\mathrm{PCO}_{2}\right.$ water $/ \mathrm{PCO}_{2}$ atmosphere $\left.=14\right)($ White, 1988).

Because several factors can affect $\mathrm{PCO}_{2}$, a better indicator of conduit flow is calcite saturation. The calcite saturation index 
Table 6. Data from previous studies of water from Ridge and Valley carbonate aquifers in Pennsylvania (Langmuir and Jacobson, 1971) showing geochemical indicators of source of water.

[mg/L, milligrams per liter; atm, atmosphere]

\begin{tabular}{|c|c|c|c|c|c|c|c|}
\hline \multirow[b]{2}{*}{ Source of water } & \multicolumn{7}{|c|}{ Geochemical indicators } \\
\hline & $\begin{array}{c}\text { Specific } \\
\text { conductance } \\
\text { (microsiemens } \\
\text { per centimeter } \\
\text { at } 25^{\circ} \mathrm{C} \text { ) }\end{array}$ & $\mathrm{pH}$ & $\begin{array}{c}\text { Alkalinity } \\
(\mathrm{mg} / \mathrm{L} \text { as } \\
\left.\mathrm{CaCO}_{3}\right)\end{array}$ & $\begin{array}{c}\text { Partial } \\
\text { pressure } \\
\mathrm{CO}_{2} \\
\text { (atm) }^{1}\end{array}$ & $\begin{array}{l}\text { Calcite } \\
\text { saturation } \\
\text { index }\end{array}$ & $\begin{array}{l}\text { Dolomite } \\
\text { saturation } \\
\text { index }\end{array}$ & $\begin{array}{l}\text { Calcium- } \\
\text { magnesium } \\
\text { molar ratio }\end{array}$ \\
\hline Limestone springs & 315 & 7.29 & 134.0 & -2.17 & -0.52 & -0.86 & 5.23 \\
\hline $\begin{array}{l}\text { Dolomite springs } \\
\text { (non-Gatesburg) }\end{array}$ & 416 & 7.49 & 183.0 & -2.23 & -.2 & -.22 & 1.04 \\
\hline Limestone wells & 569 & 7.31 & 234.0 & -1.95 & -.07 & -.27 & 2.97 \\
\hline $\begin{array}{l}\text { Dolomite wells } \\
\text { (non-Gatesburg) }\end{array}$ & 542 & 7.34 & 237.0 & -1.92 & -.18 & -.17 & .94 \\
\hline Gatesburg wells and springs & 276 & 7.93 & 132.0 & -2.82 & -.1 & -.11 & 1.06 \\
\hline
\end{tabular}

\footnotetext{
${ }^{1} \log$ of atmospheric pressure.
}

Table 7. Data on geochemical indicators of type of permeability from previous studies of Ridge and Valley carbonate aquifers in Pennsylvania.

[mg/L, milligrams per liter; atm, atmosphere; --, no data]

\begin{tabular}{|c|c|c|c|c|c|c|c|c|}
\hline Type of permeability & \multicolumn{8}{|c|}{ Geochemical indicator } \\
\hline Primary & -- & High & -- & Low & Saturated & Saturated & Low & $\begin{array}{l}\text { Langmuir and White } \\
\text { (1971) values by } \\
\text { type of } \\
\text { permeability }\end{array}$ \\
\hline Conduits (springs) & 112 & -- & -- & -2.38 & -0.89 & -- & -- & \multirow{3}{*}{$\begin{array}{l}\text { White (1988) values } \\
\text { for types of } \\
\text { permeability }\end{array}$} \\
\hline Diffuse flow (springs) & 200 & -- & -- & -2.22 & -.24 & -- & -- & \\
\hline Fracture zones (wells) & 288 & -- & -- & -2.00 & -.13 & -- & -- & \\
\hline Conduits (springs) & -- & -- & 108 & -2.41 & -.52 & -- & 4.5 & $\begin{array}{l}\text { Scanlon and } \\
\text { Thrailkill (1987) }\end{array}$ \\
\hline
\end{tabular}

(SIc) is the ratio between the ion activity product and the solubility product for calcite. Waters with indices less than 1 are undersaturated, an index of 1 is at saturation, and indices greater than 1 are supersaturated. The SIc is affected by lithology, and waters with the longer transport times associated with diffuse flow and fracture permeability typically are more saturated with respect to calcite than waters moving rapidly through a conduit system with much less contact with the bedrock. Data from karst waters in the North Central Appalachian Mountains show that diffuse-flow springs and wells have a higher SIc (-0.24 and -0.13 , respectively) than conduit-flow springs (-0.89) (White, 1988).

\section{Anthropogenic Contaminants}

The sampling for anthropogenic contaminants included nutrients, $\delta^{15} \mathrm{~N}$, and compounds indicative of wastewater. The nutrient analyses included nitrogen and phosphorus species. Nitrate is the main contaminant of concern in the ground water; however, occurrence of phosphorus also is considered important. The $\delta^{15} \mathrm{~N}$ ratio is considered important in determining whether the source of nitrogen is chemical fertilizer or organic waste such as manure or septic systems. The wastewater analysis included multiple indicators of human wastewater, such as caffeine and cholesterol, hormones, pesticides, and volatile organic compounds (VOCs). The analysis was developed by the USGS to detect chemicals commonly expected in wastewater (Zaugg and others, 2002). Other possible indicators of contamination by on-lot sewage disposal systems (septic tanks), such as boron concentration and comparisons of chloride-bromide $(\mathrm{Cl} / \mathrm{Br})$ ratios, also were analyzed.

To further classify possible sources of nitrogen in agricultural areas, the origin of fertilizer (inorganic chemical or manure) was classified as well. This classification is important 


\section{Determining Sources of Water and Contaminants to Wells in a Carbonate Aquifer near Martinsburg, Pennsylvania}

information because the isotopic signature of nitrogen can vary on the basis of the source of that nitrogen (Cravotta, 1997; Böhlke, 2003). A summary of the organic (manure) or inorganic (chemical fertilizer) origin of nitrogen in the study area is illustrated in figure 11. Data from the U.S. Department of Agriculture (USDA), Natural Resources Conservation Service (NRCS) (Amanda Ritchy, U.S. Department of Agriculture, written commun., 2003) were used to classify cropland nutrient sources in the vicinity of the well fields as 1) predominantly manure (91 to 100 percent manure), 2) predominantly chemical fertilizer (0 to 10 percent manure), or 3) a mixture of chemical and manurebased fertilizers (fig. 11). This illustration shows that the predominant source of nitrogen applied in most areas is animal manure. The uptake of nitrogen by crops is not considered, and the figure is not meant to imply that any specific field has excess nitrogen applied or that nitrogen leaches to the ground water from any specific field. Areas where septic systems are used also are shown in figure 11 (any area not served by public sewer).

Determining the possible sources of nitrate in ground water by delineating land use may not be helpful in an area where agricultural activity is widespread; however, a nutrient mass-balance analysis can be used to help determine the sources. For example, if the areal extent of the zone of contribution to a well includes residences with on-lot septic systems and agricultural land, the amount of nitrogen generated by each can be estimated. The number of septic systems can be multiplied by a typical amount of nitrogen generated by a household to calculate the contribution by septic systems. The amount of agricultural nitrogen applied per acre (with allowances for nitrogen uptake by crops) can be computed as well. The proportion of nitrogen from each source can help determine which source is contributing the greatest amount of nitrogen to the ground water. Although specific amounts of nitrogen applied to cropland was not available to make this calculation, the number of septic systems could be estimated to allow a calculation of the part of the nitrogen contributed by septic systems by (eqn. 1):

$$
C_{w}=\left(C_{e} \times V_{e} \times n\right) / V_{w}
$$

where

$C_{w}$ is the concentration of nitrogen in the municipal well due to septic effluent;

$C_{e}$ is concentration of nitrogen in septic effluent (85 mg/L - Miller, 1980);

$V_{e}$ is the volume of septic effluent per person per day (170 L/day - Miller, 1980);

$n$ is the number of people using septic systems in the areal extent of the zone of contribution to the well;

and $V_{w}$ is the volume of water pumped per day by the
municipal well.

Assuming that the system is in a steady state where the volume of water withdrawn and the nitrogen mass input are the same over a period of several years, and that there is no component of old, nitrogen-free water diluting the nitrogen, the storage of water can be ignored and the concentration in the water in the zone of contribution to a well can be calculated by dividing the nitrogen mass input by the volume pumped from the municipal well in a given time period. This concentration will result in the highest possible nitrogen concentration that the septic systems could contribute, because there is probably some component of dilution by older water and there are losses to volatilization, denitrification, and plant uptake that are not considered in this calculation.

Nitrogen occurs as two stable isotopes, ${ }^{15} \mathrm{~N}$ and ${ }^{14} \mathrm{~N}$, and the ratio ${ }^{15} \mathrm{~N}:{ }^{14} \mathrm{~N}$ is reported relative to a standard, in per mil (see table of contents for further description of notation, standards and units). The $\delta^{15} \mathrm{~N}$ can provide information on sources of nitrogen in nitrate. Cravotta (1997) compared $\delta^{15} \mathrm{~N}$ values in surface water with animal manure, fertilizer, and human waste and found a wide range within a nitrogen source and some overlap among sources. The range of the 15 th to 85 th percentile of $\delta^{15} \mathrm{~N}$ was about +4 to +21 per mil for animal manure with a median near +10 , fertilizer had a range from -2 to +3 per mil with a median near 0 , septic-tank effluent ranged from -2 to +4 per mil with a median of near 1 per mil, and sewage sludge had a range of +1 to +11 per mil with a median of 8 (fig. 13). Cravotta found that fractionation caused significant changes in the isotope ratios during transport from source areas; processes that transform nitrogen affect the lighter isotope disproportionally, resulting in higher $\delta^{15} \mathrm{~N}$ than would be expected on the basis of the source material. Processes such as volatilization, residual nitrogen in soils, and denitrification can obscure the relations between $\delta^{15} \mathrm{~N}$ in sources and environmental samples (Böhlke, 2003), and the potential for these transformation processes must be scrutinized for each sample before using $\delta^{15} \mathrm{~N}$ to infer nitrogen sources. In findings consistent with those of Cravotta (1997), Böhlke (2003) found that $\delta^{15} \mathrm{~N}$ was lower in water recharged beneath fields receiving chemical fertilizers $(+2$ to +6 per mil) than in water recharged beneath fields receiving manure $(+10$ to +20 per mil) or water recharged through septic systems $(+8$ to +11 per mil).

\section{Microbial Source Tracking}

Microbial source tracking was conducted to help differentiate among human, livestock, and other possible sources of bacteria in the municipal water supply. Microbial source tracking is a term used for a variety of microbiological methods to attempt to identify probable sources of fecal bacteria identified in the environment. Antibiotic resistance patterns (ARPs) of fecal-coliform bacteria were analyzed by the Environmental Microbiology Laboratory at the Pennsylvania State University Capitol Campus in order to determine whether potential sources of nitrate originate from human or livestock waste. ARPs of fecal coliforms were used to evaluate the importance of the agricultural activity as a source of fecal contamination in Morrison Cove. ARP analysis requires that samples from all likely fecal sources are collected, and the bacteria isolated from these source samples are tested for resistance against a broad spec- 

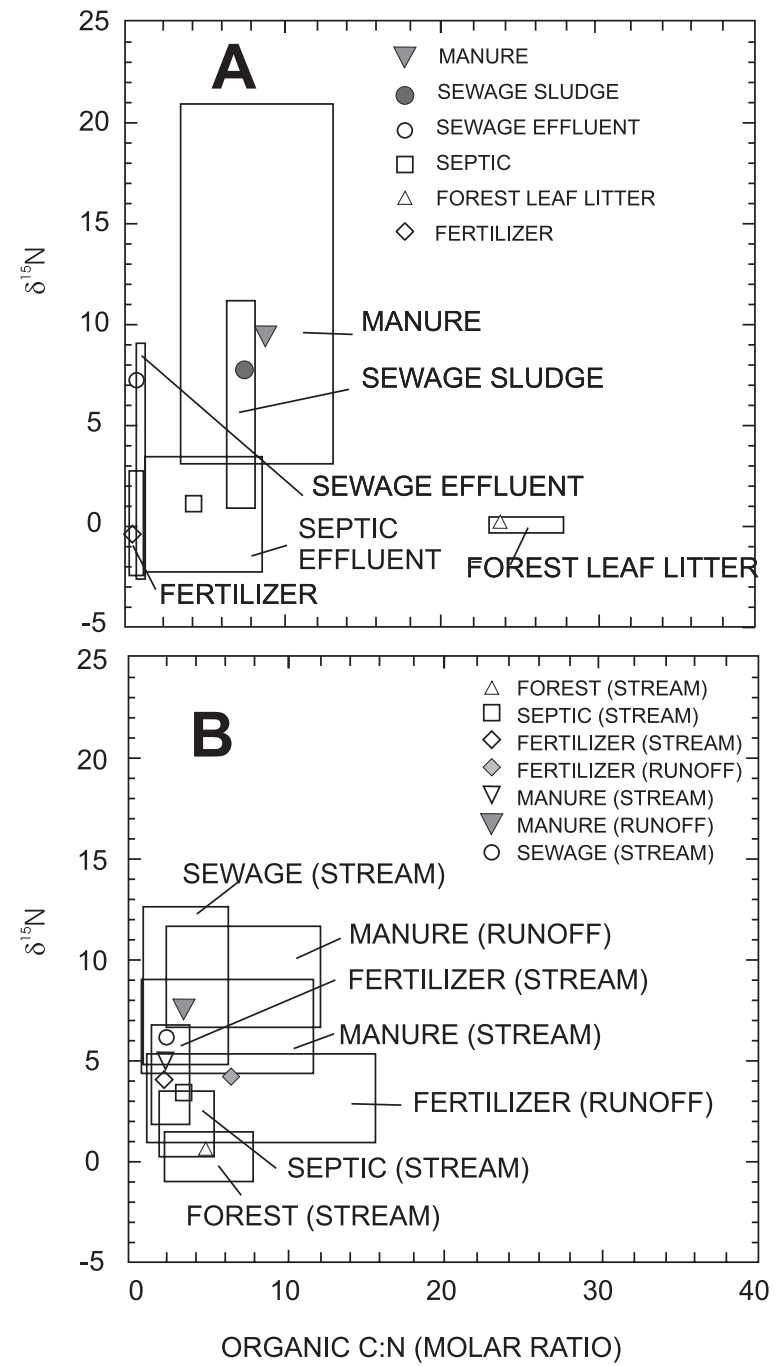

trum of antibiotics. Samples of bacteria isolated from environmental samples are tested for resistance against that same spectrum of antibiotics, and a discriminant analysis is conducted to determine if the environmental samples are in the same statistical cluster of resistance patterns as one of the known source samples. Samples of dairy cattle feces (the only major type of animal livestock in this area) and untreated samples from the Martinsburg Wastewater Treatment Facility were collected, and the fecal coliforms isolated were characterized in terms of their ARPs using the methods described by Hagedorn and others (1999), Harwood and others (2000), and Wiggins and others (1999). The ARPs from data collected in the Martinsburg area were determined by using the methods outlined in these previous studies (Dr. Katharine Baker, Pennsylvania State University, written commun., 2003).

Two sets of environmental samples from wells were collected from September through October 2002. These samples were used to isolate fecal coliforms for the ARPs. The ARPs of the isolates were compared to the database developed to determine if the dairy-cattle population is the major source of fecal contamination to the area. Quality assurance of the ARPs was

\section{EXPLANATION}

\author{
85th PERCENTILE \\ MEDIAN \\ 15th PERCENTILE
}

Figure 13. $\delta^{15} \mathrm{~N}$ relative to organic carbon: total nitrogen for (A) nitrogen-source materials, and (B) suspended particulates in water, Susquehanna River Basin, Pennsylvania (from Cravotta,1997).

performed by analyzing replicate isolates (approximately 1 percent of the total isolates) and known cultures of fecal coliforms obtained from commercial culture collections. In addition, an uninoculated control was run with every set of antibiotic sensitivity determinations.

\section{Simulation of Ground-Water Flow}

The areal extent of the zone of contribution is the volume of the aquifer that contributes water to a well and all pathlines from the recharge area to the well, projected to the land surface. The zone of contribution cannot be measured directly, however, the ground-water-flow model MODFLOW (Harbaugh and others, 2000) was used to simulate ground-water-flow directions and the areal extent of the zone of contribution. The details of the ground-water modeling are presented in detail later in this report. 


\section{Sources of Water and Contaminants to Martinsburg Municipal Wells}

Various methods were used to determine the sources of water and contaminants to the Martinsburg municipal supply wells. The methods were analysis of the geochemical indicators, anthropogenic contaminants, and the simulation of ground-water-flow. These approaches were analyzed independently and then were compared to each other to determine if the various methods indicated similar conclusions.

\section{Geochemical Indicators}

Various water-quality analyses were conducted to assist in classifying the source of water and contaminants to wells. These analyses included major ions, nitrate and other nutrients, wastewater compounds, and microbiological contaminants. Results of water-quality analyses collected during this study are published in Durlin and Schaffstall (2003).

\section{Source of Water}

Ground water contains dissolved minerals that vary on the basis of the type of bedrock it has been in contact with. Although bedrock in the study area has similar chemical compositions, geochemistry of water still can be used to help determine the source of water to a given well. As previously discussed, water from a dolomite aquifer would be expected to have a slightly different geochemical composition than water from a limestone aquifer. Water from a well completed in one aquifer may have traveled through other aquifers to get to that well and, therefore, has a mixed chemical composition.

Well BA 543 (fig. 12) was completed in shale, and the water from this well had a different geochemical composition than water from the other wells sampled during this study. Results from this well are not included in most geochemical comparisons where ranges are given and results from carbonate aquifers are compared to each other.

Langmuir and White (1971) found many comparisons of geochemical constituents that were useful to distinguish water with five distinct sources: limestone springs, limestone wells, dolomite springs (other than the Gatesburg aquifer), dolomite wells (other than the Gatesburg aquifer), and water from wells and springs in the Gatesburg aquifer. Water from the Gatesburg aquifer was found in most cases to be appreciably different from water in other carbonate rocks (Langmuir and White, 1971). The data from the wells sampled for this study were compared to their results. Some of these comparisons were based on field measurements, others were based on laboratory results, and others were values calculated for comparison.

The calcium/magnesium molar ratios in ground water from this study ranged from 1.04 to 9.18 . When compared to Langmuir and White (1971), samples from wells and the spring in the Coburn-Loysburg aquifers had ratios that indicated a limestone source; the Bellefonte/Axemann, Nittany/Stonehenge, and Gatesburg aquifers had ratios that indicated a dolomite source (fig. 14). The geochemical indications for a limestone source in the Coburn-Loysburg aquifers suggested that the water-bearing zones in these wells may have been in the Upper Ordovician limestone lithologies (table 1) of this aquifer. The only exception to this pattern was well BA 433, which had an abnormally high sodium concentration (fig. 14). This may have been a result of anthropogenic contamination or a highly mineralized zone. In general, the geochemical composition of water matched values that would be expected on the basis of the lithology of the aquifers where samples were collected. Those wells in aquifers with more pure limestone compositions had water that geochemically was similar to ground water from limestone wells as reported by Langmuir and White (1971). Some wells were completed in aquifers that could contain limestone or dolomite, and water from those wells indicated mixed geochemical signatures. Municipal well BA 545 had a geochemical signature that indicated a dolomite source, and well BA 332 had a geochemical signature that indicated a mixed limestone and dolomite source.

\section{Type of Permeability}

The type of permeability (primary, fracture, and conduit) is one factor affecting the geochemical composition of waters. As previously stated, primary permeability was considered to be minimal in the study area. The geochemistry of water that travels through fractures generally is affected by the large amount of contact time with the rock matrix and isolation from the atmosphere. The geochemistry of water that travels through large solution conduits and caverns is affected by less contact with the rock matrix and more contact with atmospheric air than water traveling through fractures. Geochemical data collected in the current study were compared to the findings of previous studies (table 7) to determine which of the three types of permeability was present in this ground-water system. Calcite saturation, $\mathrm{PCO}_{2}$, alkalinity, and specific conductance values of samples from wells indicated that fractures were the dominant pathway of ground-water flow.

SIc in ground water ranged from -0.27 to 0.03 (table 8). These data were all in the range reported by previous studies in fracture-flow systems. Values of -0.52 (Scanlon and Thraillkill, 1987) to -0.87 (White, 1988) would be indicators of conduit flow. Ground water in this system appeared to have sufficient amount of contact with the aquifer to have higher SIc than expected in conduit-flow systems consistent with longer residence times or a tortuous fracture flow path.

All of the $\log \mathrm{PCO}_{2}$ values in ground water were greater than -2.4 (table 8 ), a value shown by previous studies to indicate conduit flow (Scanlon and Thraillkill, 1987; White, 1988). The two wells that had $\log \mathrm{PCO}_{2}$ values less than -2 were wells BA 545 and BA 547, which had $\mathrm{PCO}_{2}$ values of -2.03 and -2.21 , 


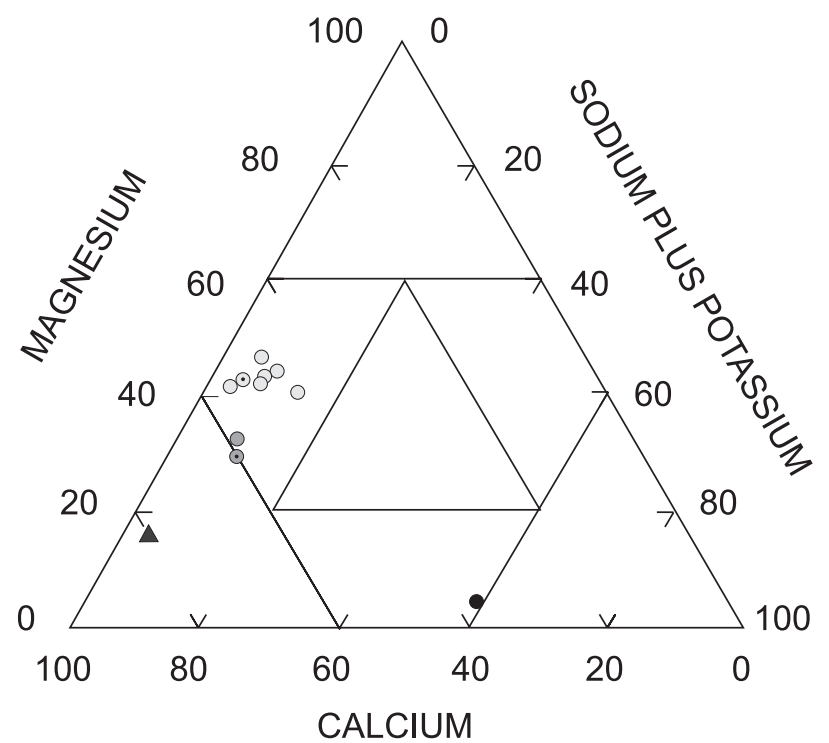

(Percentage of milliequivalents per liter)

\section{EXPLANATION}

- WELL NEAR MARTINSBURG WITH DOLOMITE WATER SOURCE

- WELL NEAR MARTINSBURG WITH MIXED LIMESTONE AND DOLOMITE WATER SOURCE

- LIMEStONE SPRING BA Sp 23

- WELL BA 433

$\odot \quad$ MUNICIPAL WELL BA 545

• MUNICIPAL WELL BA 332

Figure 14. Concentrations of major ions in water from wells near Martinsburg, Pennsylvania.

Table 8. Geochemical composition of water from wells sampled near Martinsburg, Pennsylvania. [atm, atmospheres]

\begin{tabular}{|c|c|c|c|c|c|c|c|c|c|}
\hline $\begin{array}{c}\text { County } \\
\text { well } \\
\text { number }\end{array}$ & Aquifer & Lithology & $\begin{array}{c}\text { Specific } \\
\text { conductance } \\
\text { (micro- } \\
\text { siemens per } \\
\text { centimeter at } \\
25^{\circ} \mathrm{C} \text { ) }\end{array}$ & $\mathbf{p H}$ & $\begin{array}{c}\text { Alkalinity } \\
\text { (mg/L as } \\
\mathrm{CaCO}_{3} \text { ) }\end{array}$ & $\begin{array}{c}\text { Log partial } \\
\text { pressure of } \\
\mathrm{CO}_{2} \\
\text { (atm) }\end{array}$ & $\begin{array}{c}\text { Calcite } \\
\text { saturation } \\
\text { index }\end{array}$ & $\begin{array}{l}\text { Dolomite } \\
\text { saturation } \\
\text { index }\end{array}$ & $\begin{array}{l}\text { Calcium- } \\
\text { magnesium } \\
\text { molar ratio }\end{array}$ \\
\hline BA 544 & Bellefonte/ Axemann & Dolomite/ Limestone & 1,084 & 6.80 & 313 & -1.33 & -0.27 & -0.46 & 1.14 \\
\hline BA 546 & Bellefonte/ Axemann & Dolomite/ Limestone & 873 & 6.70 & 421 & -1.04 & -.12 & -.46 & 1.31 \\
\hline BA 549 & Bellefonte/ Axemann & Dolomite/ Limestone & 783 & 6.98 & 294 & -1.53 & -.19 & -.28 & 1.17 \\
\hline BA 550 & Bellefonte/ Axemann & Dolomite/ Limestone & 960 & 6.94 & 349 & -1.43 & -.14 & -.22 & 1.04 \\
\hline BA $545^{1}$ & Gatesburg & Dolomite & 469 & 7.30 & 189 & -2.03 & -.24 & -.43 & 1.23 \\
\hline BA $332^{1}$ & Nittany/Stonehenge & Dolomite/ Limestone & 557 & 7.13 & 267 & -1.67 & .03 & -.30 & 1.78 \\
\hline BA 547 & Nittany/Stonehenge & Dolomite/ Limestone & 499 & 7.43 & 170 & -2.21 & -.18 & -.32 & 1.02 \\
\hline BA 548 & Nittany/Stonehenge & Dolomite/ Limestone & 682 & 7.30 & 222 & -1.96 & -.10 & -.16 & 1.10 \\
\hline BA 433 & $\begin{array}{l}\text { Coburn through } \\
\text { Loysburg Undivided }\end{array}$ & Limestone & 2,440 & 6.80 & 324 & -1.32 & -.15 & -1.17 & 9.18 \\
\hline BA Sp 23 & $\begin{array}{l}\text { Coburn through } \\
\text { Loysburg Undivided }\end{array}$ & Limestone & 519 & 7.21 & 203 & -1.92 & -.10 & -.73 & 4.66 \\
\hline BA $543^{2}$ & Reedsville & Shale & 277 & 7.55 & 96 & -2.56 & -.46 & -1.27 & 2.12 \\
\hline
\end{tabular}

${ }^{1}$ Municipal supply wells (dark shading).

${ }^{2}$ Well completed in shale was not used in comparisons in text (light shading). 
respectively. The value in well BA 545 was much closer to the values associated with fracture-flow in limestone wells $(-2.00)$ than the value associated with conduit-flow springs $(-2.38)$ (table 7). Well BA 547 is in an area with a large number of closed depressions and water chemistry may be influenced by conduit flow. These wells are in or near the Gatesburg aquifer, which according to Langmuir and Jacobson (1971) has log $\mathrm{PCO}_{2}$ values in the range of -2.82 .

Specific conductance and alkalinity values also are indicators of residence times or the amount of contact that water has with the bedrock. The values of specific conductance in ground water ranged from 469 to $2,440 \mu \mathrm{S} / \mathrm{cm}$. Some of the higher values may be affected by anthropogenic contaminants. High specific-conductance values also could indicate long residence times or wells completed in zones of unusually high mineral content. None of the values were near the mean value of $112 \mu \mathrm{S} / \mathrm{cm}$ measured in conduit-flow springs by White (1988). The values of alkalinity in ground water ranged from 170 to $421 \mathrm{mg} / \mathrm{L}$ as $\mathrm{CaCO}_{3}$. Alkalinity values were all near or greater than the values of alkalinity measured in diffuse-flow springs (175 mg/L, Scanlon and Thraillkill, 1987) and none were as low as the values measured in conduit-flow springs $(108 \mathrm{mg} / \mathrm{L}$, Scanlon and Thraillkill, 1987).

\section{Sources Based on Analysis of Anthropogenic Contaminants}

Anthropogenic contaminants were measured in ground water and streams to determine their occurrence and distribution as well as to indicate potential sources of ground water. Some indicators, such as $\delta^{15} \mathrm{~N}$, are useful in distinguishing chemical-fertilizer sources from manure sources. Wastewater compounds such as caffeine, cholesterol, and human steroids can help determine whether or not human sewage is a likely source of ground-water contamination. $\mathrm{Cl} / \mathrm{Br}$ ratios also can indicate anthropogenic effects on ground-water quality.

\section{Nitrate-Nitrogen}

The predominant form of nitrogen detected in samples was nitrate. Concentrations of nitrite plus nitrate in ground water from the carbonate aquifers ranged from 5.73 to $36.9 \mathrm{mg} / \mathrm{L}$ as nitrogen (table 9). Well BA 543 was completed in shale and had

Table 9. Selected chemical analyses from wells, streams, and a spring sampled near Martinsburg, Pennsylvania.

$\left[\mathrm{mg} / \mathrm{L}\right.$, milligrams per liter; $\mu \mathrm{g} / \mathrm{L}$, micrograms per liter; $\delta^{15} \mathrm{~N}$, Nitrogen isotope ratio N15/N14, in per mil; E, value is estimated but below the level that can be quantified accurately with the analytical instruments; M, substance was identified positively, but no value can be assigned to the detection because of the uncertainty of the measurement; NS, insufficient bacteria for analysis;--, not analyzed]

\begin{tabular}{|c|c|c|c|c|c|c|c|}
\hline $\begin{array}{l}\text { County well number, } \\
\text { spring number, } \\
\text { of stream name }\end{array}$ & $\begin{array}{l}\text { Oxygen, } \\
\text { dissolved } \\
\text { (mg/L) }\end{array}$ & $\begin{array}{c}\text { Nitrogen, } \\
\text { nitrite plus nitrate, } \\
\text { dissolved } \\
\text { (mg/L } \\
\text { as nitrogen) }\end{array}$ & $\begin{array}{c}\text { Nitrogen, } \\
\text { nitrate plus } \\
\text { nitrite, } \\
\text { dissolved } \delta{ }^{15} \mathrm{~N} \\
\text { (per mil) }\end{array}$ & $\begin{array}{l}\text { Boron, } \\
\text { dissolved } \\
\text { ( } \mu \mathrm{g} / \mathrm{L} \text { as } \\
\text { boron) }\end{array}$ & $\begin{array}{l}\text { Chloride - } \\
\text { bromide } \\
\text { ratio }\end{array}$ & $\begin{array}{c}\text { Wastewater } \\
\text { compounds } \\
\text { (number detected } \\
\text { out of } \\
67 \text { compounds }^{1} \text { ) }\end{array}$ & $\begin{array}{c}\text { Percentage of bacteria } \\
\text { isolates matching } \\
\text { source }^{2}\end{array}$ \\
\hline \multicolumn{8}{|c|}{ Well and Spring Sites } \\
\hline BA 544 & 4.0 & 36.9 & 9.4 & E 10 & 1,186 & 1 & NS \\
\hline BA 549 & 3.7 & 10.5 & 6.4 & 10 & 1,350 & 3 & NS \\
\hline BA 550 & 4.4 & 5.73 & -- & E 10 & -- & -- & NS \\
\hline BA $545^{3}$ & 9.2 & 8.92 & 4.1 & M & 710 & 1. (metolachlor) & NS \\
\hline BA $332^{3}$ & 7.1 & 9.16 & 6.0 & 20 & 1,355 & 4 & NS \\
\hline BA 547 & 8.2 & 16.8 & 7.4 & E 10 & 427 & 1 & Cattle $-100 \%$ \\
\hline BA 543 & .2 & .11 & -- & 20 & -- & -- & Cattle $-83 \%$ \\
\hline \multicolumn{8}{|c|}{ Stream Sites } \\
\hline Piney Creek & 5.5 & 7.92 & 8.3 & 20 & 4 & 2 & Cattle $-93 \%$ \\
\hline Clover Creek & 8.3 & 5.35 & 5.2 & E 10 & $4_{--}$ & 1 & Cattle $-86 \%$ \\
\hline Tributary to Plum Run & 6.0 & .80 & 6.6 & 20 & ${ }^{4}--$ & 6 & Cattle $-88 \%$ \\
\hline Cove Creek & 3.0 & 1.65 & 11.3 & 220 & 7,666 & 20 & Cattle $-88 \%$ \\
\hline
\end{tabular}

\footnotetext{
${ }^{1}$ Includes estimated and unquantified values, entire list of analytes is available in Durlin and Schaffstall (2003).

${ }^{2}$ Data summarized from Dr. Katharine Baker, Pennsylvania State University, written commun., 2003.

${ }^{3}$ Municipal supply wells (shading).

${ }^{4}$ Bromide measured but not detected, therefore, no ratio shown.
} 
a concentration of $0.11 \mathrm{mg} / \mathrm{L}$. These results were consistent with previous studies conducted in this area (Lindsey and others, 1997; Coyle, 1998). Municipal supply wells BA 545 and BA 332 had concentrations of 8.92 and $9.16 \mathrm{mg} / \mathrm{L}$, respectively. The USGS results for water from these wells were consistent with the concentrations typically measured by Martinsburg Borough for routine sampling in these wells (Randy Stoltz, Martinsburg Borough, written commun., 2003).

\section{Nitrogen Isotopes}

The $\delta^{15} \mathrm{~N}$ values in ground water in the study area ranged from +4.1 to +9.4 per mil (table 9). Although $\delta^{15} \mathrm{~N}$ values can be affected by denitrification, the relatively high dissolved oxygen concentrations ( 2.4 to $9.2 \mathrm{mg} / \mathrm{L}$ ) in samples from wells where isotopes were measured suggested that denitrification was minimal (Böhlke, 2003). The $\delta^{15} \mathrm{~N}$ values were in the range that could indicate nitrate in ground water originates from either organic-nitrogen sources (human sewage or animal manure) or chemical fertilizer. Values close to +10 per mil in samples from BA 546 and BA 548 (table 9) were more likely derived from animal sources, while values lower than +6 per mil were likely derived from chemical fertilizer. The sample collected on Cove Creek downstream from the Martinsburg Wastewater Treatment Plant had a value $(+11.3$ per mil) in the range that would be expected for human sewage or animal manure. Water from well BA 545 had a value of +4.1 per mil, and well BA 332 had a value of +6.0 per mil. The value in water from well BA 332 indicated a mixture of chemical fertilizer and organic (human sewage or animal manure) sources of nitrogen. The high end of the range of $\delta^{15} \mathrm{~N}$ values for septic effluent is about +4.0 per mil (fig. 13), therefore; septic systems cannot be ruled out as a potential source of nitrogen to well BA 545 on the basis of the nitrogen isotope results.

\section{Chloride/Bromide Ratio}

Chloride and bromide are useful indicators of anthropogenic contamination because they are 1) highly soluble, 2) minimally affected by adsorption once dissolved in water, and 3) not altered by oxidation-reduction reactions (Hem, 1985). High concentrations (greater than 10,000 mg/L) of chloride can be found in evaporite deposits in carbonate rocks (Hem, 1985); however, evaporite deposits causing elevated chloride concentrations are not likely in the study area. Sources of chloride included septic systems, animal waste, fertilizer, and road salts. The chloride present in fertilizer commonly is in the form of potassium chloride, also known as potash (Lamond and Leikam, 2002). Concentration ratios of chloride to bromide vary because bromide has a higher solubility than chloride. Evaporation of sea water results in halite deposits with a high chloride-bromide ratio relative to the brine that remains. This halite applied as road salt and dissolved in freshwater will subsequently have a high chloride-bromide ratio as well. Chloridebromide ratios in precipitation are typically in the range of 50 to
100; sewage ratios are in the 300 to 600 range, and halite ratios are in the range of 1,000 to 10,000 (Davis and others, 1998). Mixing ratios of chloride-bromide plotted against chloride for septic effluent, halite, and a combination of septic effluent and halite were developed by Jagucki and Darner (2001) (fig. 15). End members of chloride-bromide ratios for halite (A) are from Knuth and others (1990), the domestic sewage end member (B) is from Jagucki and Darner (2001), and the dilute ground-water end member (C) is from Low and Conger (2002). Chloride-bromide ratios from ground-water samples collected in this study fell between mixtures indicating domestic sewage and halite, and all were above the ratio of 400 that Jagucki and Darner (2001) established as a threshold to indicate influence from anthropogenic sources. It was difficult to assess the relative magnitude of these sources of water on the basis of these data because all the potential sources could have contributed to the observed ratios, and end members for chemical fertilizer and animal manure are unknown.

\section{Boron}

Boron indicates possible sewage contamination because it is found in human sewage as a residue of detergents. Boron was used by Bassett and others (1995) to identify municipal wastewater that had been injected in an aquifer. Concentrations of boron in ground-water samples in the study ranged from 10 to $20 \mu \mathrm{g} / \mathrm{L}$ indicating a low likelihood of sewage or industrial contamination (Hem, 1985). In contrast, the surface-water sample collected in Cove Creek downstream from the Martinsburg Wastewater Treatment Plant had a boron concentration of $220 \mu \mathrm{g} / \mathrm{L}$, near the range found by Bassett and others (1995) in their study of treated sewage effluent (270 to $300 \mu \mathrm{g} / \mathrm{L}$ ).

\section{Wastewater Compounds}

Samples were analyzed for 67 organic chemicals typically found in domestic and industrial wastewater (Zaugg and others, 2002) collectively referred to herein as wastewater compounds. The compounds analyzed include surfactants, food additives, antioxidants, flame retardants, plasticizers, industrial solvents, fecal sterols, polycyclic aromatic hydrocarbons, and high-use pesticides (Zaugg and others, 2002). Seven compounds on the wastewater-analysis schedule were detected in wells (pyrene, fyrol, bromoform, isophorone, metolachlor, DEET, and Tri (2-butoxylethyl) phosphate). The sites where wastewater compounds were detected are given in table 9. All these detections were either at or below the detection limit. The values were reported as "estimated" or "unquantified." Estimated indicates the value is below the level that can be quantified accurately with the analytical instruments. Unquantified indicates a substance was identified positively, but no value can be assigned to the detection because of the uncertainty of the measurement. The compounds detected have the following uses-pyrene: coal tar and asphalt; fyrol: plasticizer and flame retardant; bromoform: wastewater ozonation by-product; isophorone: solvent; 


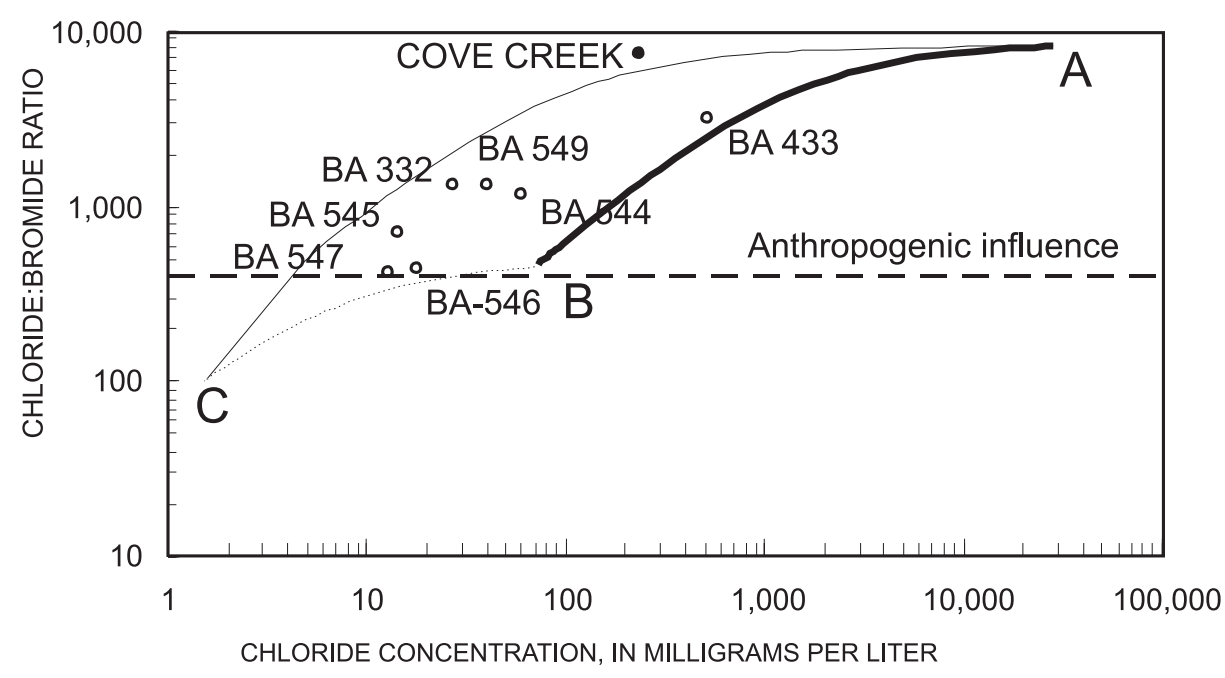

EXPLANATION

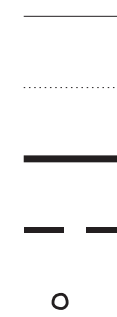

MIXING RATIO - DILUTE GROUND WATER AND HALITE

MIXING RATIO - DILUTE GROUND WATER AND SEPTIC EFFLUENT

MIXING RATIO - COMBINATION OF SEPTIC EFFLUENT AND HALITE

LINE INDICATING ANTHROPOGENIC INFLUENCE

CHLORIDE-BROMIDE RATIO IN WATER SAMPLES
Figure 15. Binary mixing curves for chloride to bromide $(\mathrm{Cl}: \mathrm{Br})$ ratios for water from wells and streams near Martinsburg, Pennsylvania (mixing ratio curves modified from Jagucki and Darner, 2001). End member for halite (A) from Knuth and others, (1990); end member for domestic sewage (B) from Jagucki and Darner (2001); end member for dilute ground water (C) from Low and Conger (2002). metolachlor: agricultural (corn) herbicide; DEET: insecticide; Tri (2-butoxylethyl) phosphate: flame retardant. Metolachlor is an herbicide commonly detected in ground water in this area (Hainly and others, 2001). The other compounds detected were indicative of urban/industrial contamination rather than specific sewage-related contamination. Municipal supply well BA 332 had the greatest number of detections in ground water and is near the center of Martinsburg Borough. Low concentrations and few detections of wastewater compounds indicated that sewage was not entering ground water in substantial quantities, and therefore, domestic and municipal sewage were an unlikely source of the elevated nitrate in the municipal wells. None of the wastewater compounds detected were above USEPA MCLs.

\section{Microbial Source Tracking}

Fecal-coliform bacteria were detected in all wells and streams sampled (Dr. Katharine Baker, Pennsylvania State University, written commun., 2003); however, ARP analysis could not be conducted in four wells including wells BA 545 and BA 332 because the concentrations of bacteria were too low. For those sites with sufficient numbers of bacteria, ARP analysis of bacteria from environmental samples was compared sta- tistically with ARP analysis of bacteria from either municipal sewage or cattle. The ARP analysis resulted in the ability to identify distinct patterns for the human-sewage and dairy-cattle source samples. Of the 13 samples collected, 9 had sufficient numbers of bacteria for the statistical analysis (4 streams and 5 ground-water samples). The statistical association between the environmental samples and the known sources is given as a percentage; higher percentages indicate a closer statistical probability that an environmental sample is associated with (or in the same 'cluster' as) one of the known sources (table 9). All four samples from surface water were related closely to the dairy-cattle sources (table 9). Of the five ground-water samples with sufficient isolates for analysis, three wells and the spring were associated predominantly with dairy-cattle bacteria; 68 to 100 percent of the isolates in these samples were in the same cluster with dairy cattle. One of the wells (BA 546) was associated with human sewage; 100 percent of the isolates in the sample were in the same cluster with the human-sewage source sample (Dr. Katharine Baker, Pennsylvania State University, written commun., 2003). Although Dr. Baker did not make a positive conclusion that all bacteria were from the dairy cattle, the implication was that dairy cattle were the most likely source of the fecal bacteria detected in all streams and all but one well. 


\section{Sources Based on Simulation of Ground-Water Flow}

Ground-water flow in the area around the Martinsburg Municipal Authority wells was simulated using a three-dimensional, finite-difference modular model known as MODFLOW2000 (Harbaugh and others, 2000). The model was used to simulate recharge, movement through the aquifer, withdrawals from water-supply wells, and discharge to streams.

In carbonate aquifers, some justification needs to be made concerning whether or not a numerical model such as MODFLOW is a valid tool to simulate the ground-water-flow system. One of the basic assumptions of MODFLOW is that the dominant pathway of ground-water flow is laminar and has characteristics of flow through a porous-media aquifer such as sand. The aquifers in this study are predominantly fractured carbonate-rock aquifers. If the fracture system approximates a series of interconnected fractures with sufficient density, it can be treated as a porous-media continuum. Scanlon and others (2003) indicated that in karst aquifers, MODFLOW can be used to simulate hydraulic conductivity, flow directions, and flow volumes if the cell size is large enough to simulate an equivalent porous media. Risser and Barton (1995) list criteria that can be used to provide an indication of whether the system approximates this porousmedia continuum allowing use of numerical models such as

MODFLOW. These criteria include a smooth water-level surface in the vicinity of the well field and water that is close to saturation with respect to calcite. The water-level map by Becher (1996) (fig. 8) showed no abrupt changes in the water-table-surface contours, although this map was not detailed enough to show discontinuities if they existed. Samples from all the wells were near saturation with respect to calcite. As discussed previously, geochemical data (calcite saturation, specific conductance, alkalinity, and $\mathrm{PCO}_{2}$ ) from all the wells sampled indicated the water was likely to be from a fracture-flow system rather than a conduit-flow system. Also, the water levels in the municipal wells do not respond rapidly to precipitation events, but show seasonal fluctuations over a span of months (Randy Stoltz, Martinsburg Borough, oral commun., 2003). These factors indicated that the system was dominated by flow through an interconnected network of fractures rather than conduits, making the use of the porous-media continuum model an acceptable approach to simulating ground-water flow in this area.

All four of the wells used by Martinsburg Borough passed the Microscopic Particulate Analysis (MPA) (Susan Boutros, Environmental Associates, Ltd., written commun., 2003). The MPA (U.S. Environmental Protection Agency, 1992) requires sampling for surface-water indicators such as plant debris, algae, diatoms, insects, rotifers, giardia, and coccidia, which are characteristic of surface waters. The results of this sampling are used to determine ground waters under the direct influence of surface water. Although not conclusive, passing the MPA would be less likely if conduit flow was the predominant pathway for ground-water flow.

\section{Conceptual Model}

The initial step in simulating ground-water flow is to formulate a conceptual model of the ground-water-flow system that incorporates aquifer characteristics, recharge, and boundary conditions and presumes a dominant pathway of groundwater flow. A conceptual flow model based on a porous-media continuum does not suggest the absence of conduit-flow features in the system, but it assumes these features are not the predominant pathway at the scale of the system simulated. The conceptual model is based on available information on the hydrogeologic properties of the aquifer and the assumed boundaries of the ground-water-flow system and is used to construct the numerical model. If the results of the numerical model are aligned closely with observations measured in the field, such as water levels and streamflow, the model is assumed to be an accurate representation of the ground-water system. If the model results do not closely resemble the field data, the assumptions of the conceptual model are revisited, and the numerical model subsequently is revised.

Recharge from precipitation enters the aquifer from the land surface and then moves through unconsolidated material in the near-surface, fracture networks in the bedrock, and possibly some conduits in the bedrock. Ground water discharges to streams and wells, and some ground water may exit the model area as underflow to discharge at streams further downgradient. Although bedrock units are folded, the model approach is to simulate with horizontal layers that have aquifer properties that differ with depth and lithology. The properties of the highly weathered bedrock and unconsolidated material are assumed to vary on the basis of the parent material from which they were derived, which, in this area, is generally the bedrock directly below that material (fig. 6).

Structure, fractures, and conduits may impart horizontal anisotropy with respect to hydraulic conductivity such that conductivity is larger along the strike of beds. As shown in figure 7, bedding and cleavage are near-vertical, on a fold axis oriented N. $30^{\circ}$ E. Fractures oriented in these directions could facilitate flow in those planes. Fractures at the intersection of bedding and cleavage planes also are oriented N. $30^{\circ}$ E., but would be horizontal, facilitating flow parallel to the axial fold, but not in the vertical direction. The cross-strike fractures would have a strike of $\mathrm{N} .60^{\circ} \mathrm{W}$. and also be near vertical. These regularly oriented fractures could cause horizontal anisotropy, which could affect the highly weathered upper aquifer as well as the competent fractured-bedrock aquifer. The near-vertical orientation of most of the fractures, in addition to the presence of many karst features, could allow water to move downward rapidly and cause a component of vertical anisotropy. Ground-water flow generally follows topography to discharge at local streams; however, the regional direction of ground-water flow to the east crosses minor topographic divides and discharges to Clover Creek. 


\section{Determining Sources of Water and Contaminants to Wells in a Carbonate Aquifer near Martinsburg, Pennsylvania}

\section{Model Design}

A MODFLOW model was constructed using a grid of 52 columns and 61 rows with each grid cell being $490 \mathrm{ft}$ by $490 \mathrm{ft}$ (fig. 16). The boundaries of the area were based on surface-watershed boundaries and included the headwaters of Cove Creek, Piney Creek, and an unnamed tributary to Clover Creek (fig. 8). Boundary delineations were based on topographic divides. The municipal wells were near the headwaters of all these streams. An area of this size was chosen to allow determination of the areal extent of the zone of contribution without being constrained by the boundary conditions. No-flow boundaries represented watershed divides and drains represented streams. Constant-head boundaries represented underflow from the watershed divide east toward Clover Creek, the regional drain. The model grid was aligned at an angle approx- imately parallel to the axis of the Woodbury Anticline (N. $30^{\circ}$ E.) to simulate potential anisotropy imparted by bedding, cleavage, and cross-strike fractures.

A two-layer model was used, with layer 1 representing ground water in the highly weathered bedrock and unconsolidated material. The thickness of layer 1 was established from land-surface altitude and the estimated altitude of the top surface of competent fractured bedrock based on well casing lengths. Layer 2 represented that part of the active groundwater-flow system in fractured bedrock and was assumed to be a confined aquifer. The geologic contacts were near-vertical in this area; therefore, the geologic formations as mapped on the surface (Berg and others, 1980) were translated downward to define the zones of hydraulic conductivity for layer 1 and layer 2 (figs. 16 and 17). The depth of layer 2 was established on the

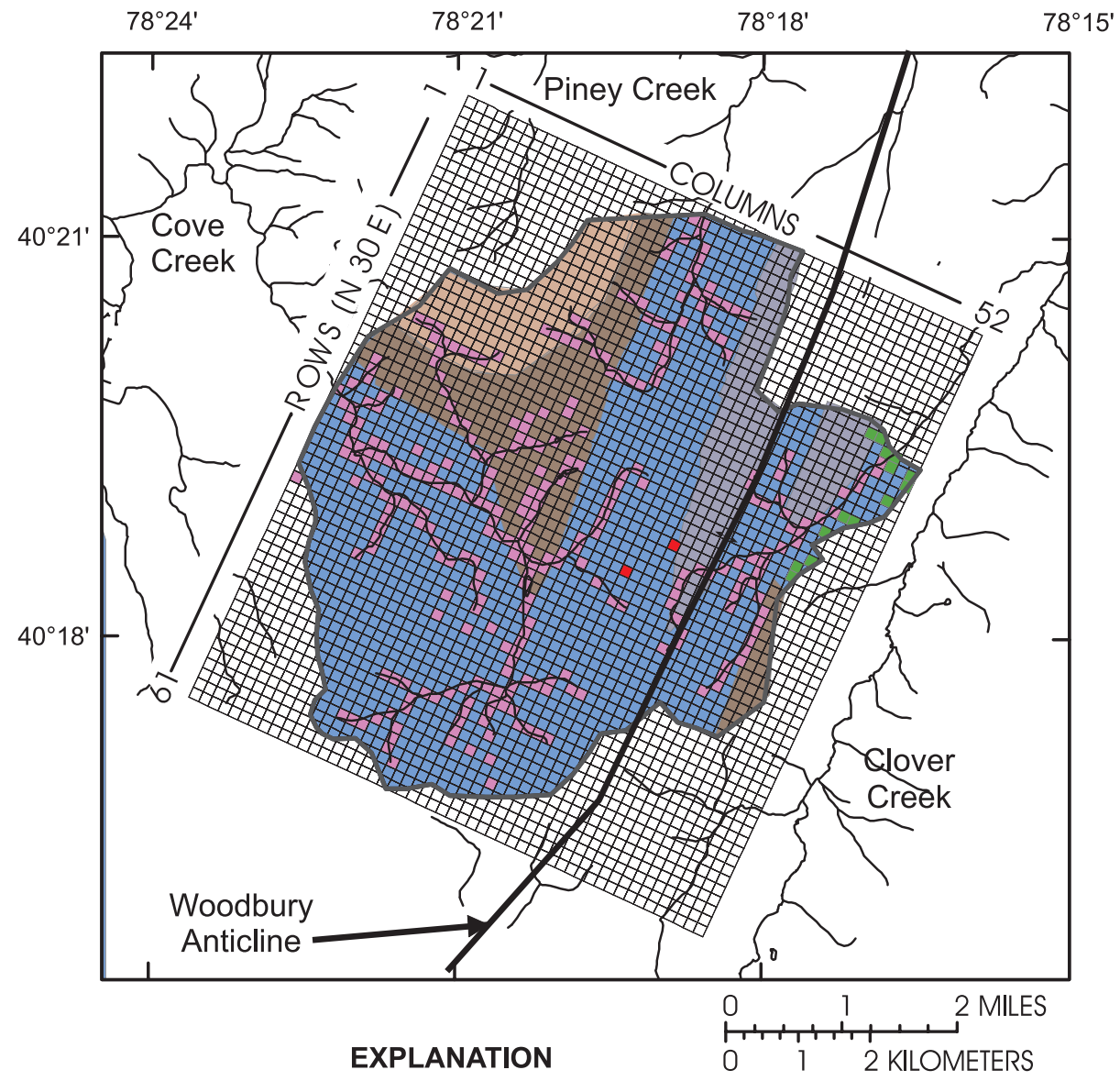

ACTIVE MODEL BOUNDARY

AQUIFER/ZONE LAYER CELL TYPE

Sandstone (Zone 1) $\square$ Grid Cell

Shale (Zone 2)

Carbonate (Zone 3)

Constant Head Cell

Gatesburg (Zone 4)

Drain Cell

Municipal Well Cell

STREAM

Figure 16. Location of model grid, boundaries, streams, drain nodes, and wells near Martinsburg, Pennsylvania. 


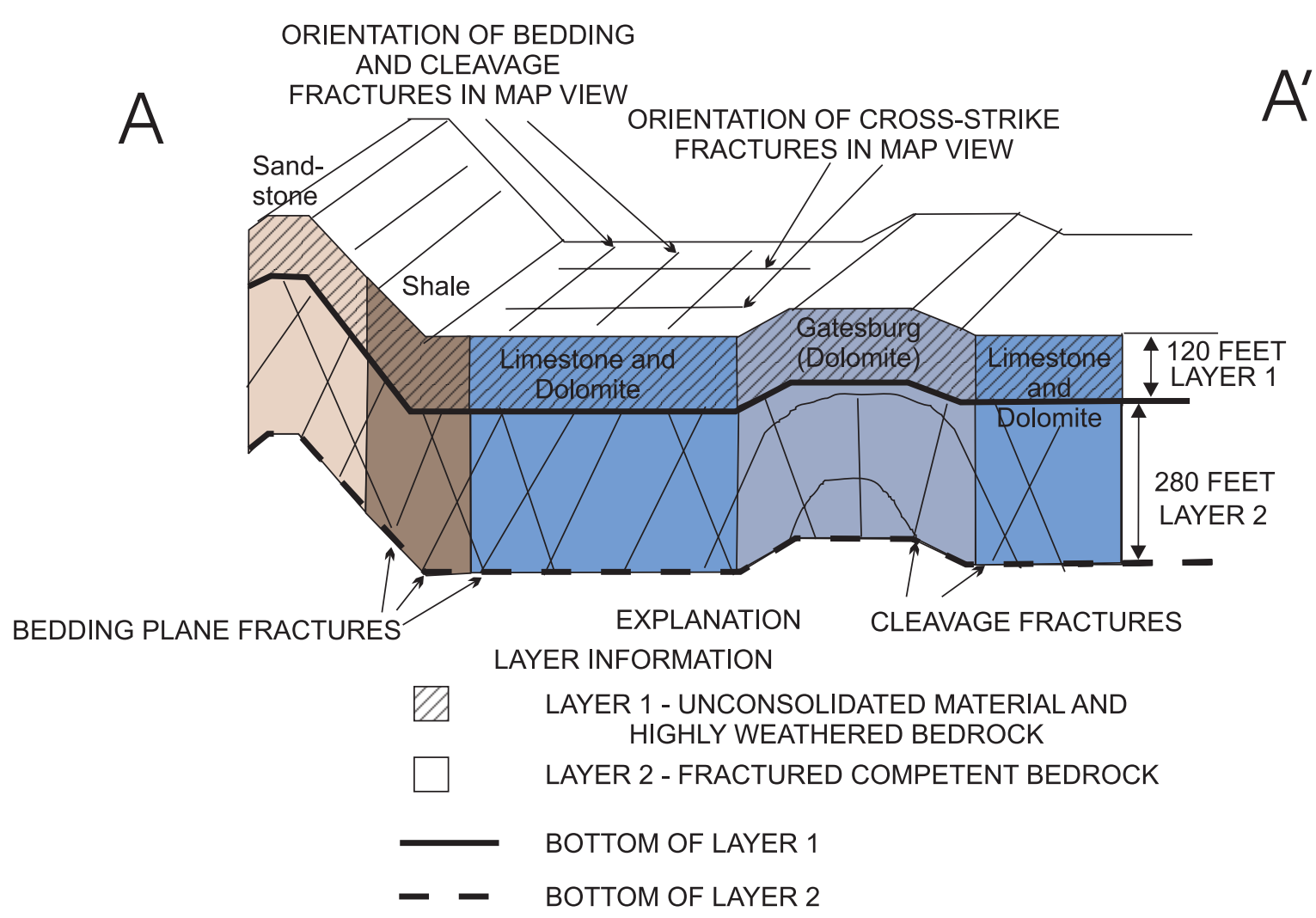

Figure 17. Hypothetical cross section of model layers used for simulation of ground-water flow. Cross section near A-A' from figure 3.

basis of well-construction information. The length of casing approximated the depth to competent bedrock and well depths were used to infer the depths of the active part of the fracturedbedrock aquifer. The 75th percentile of casing length of wells completed in carbonate bedrock in Blair County was $120 \mathrm{ft}$, which was the depth used as the interface between layer 1 and layer 2 . The 75th percentile of well depths was approximately $400 \mathrm{ft}$, which was assumed to be near the bottom of the active ground-water-flow system and was used as the bottom of layer 2 . These layer depths were used for the sandstone and shale aquifers as well.

Streams were represented in the model by drains (fig. 16) with conductance values $(3,200 \mathrm{ft} / \mathrm{d})$ much greater than the conductance of aquifer layers to allow water to enter drains with minimal resistance. The drain cells allowed ground-water discharge but not recharge; this was because although the water table may be below the stream in some locations, the streams were small headwaters streams and did not have an infinite supply of water from upstream to provide water to the aquifer at those locations. Stream width that varied from 5 to $10 \mathrm{ft}$, and streambed thickness of $3 \mathrm{ft}$ were used in the conductance calculation (Harbaugh and others, 2000). A single drain per cell was used to represent all stream locations.
Pumping from model layer 2 was simulated at the locations of the two Martinsburg municipal well fields: well BA 332, in the Hershberger well field in the borough and well BA 545 known as Well \#3 in the Wineland Well Field. Well BA 545 currently (2003) is the most productive well in the Wineland Well Field and was used to represent the entire well field. Although well BA 332 is only $100 \mathrm{ft}$ deep, it was simulated in layer 2 because its proximity to the layer boundary caused instability (dry cells) when simulated in layer 1. Numerous wells in the area are used for purposes such as domestic supply and livestock; however, these wells did not pump as much water as the municipal supply wells and were not considered in model simulation.

Values of horizontal hydraulic conductivity initially were assigned to both model layers for four aquifers - sandstone aquifers, shale aquifers, the Gatesburg aquifer, and other carbonate aquifers. The initial values assigned to these aquifers were based on the values for hydraulic conductivity from Fleeger and others (2004). The horizontal hydraulic conductivity values assigned initially to the upper layer were higher than those assigned to the lower layer to simulate decreasing hydraulic conductivity with depth. Vertical leakance controls the rate of ground-water flow between model layers, and is calculated from the thickness of each layer between its node and the com- 


\section{Determining Sources of Water and Contaminants to Wells in a Carbonate Aquifer near Martinsburg, Pennsylvania}

mon layer contact and the vertical hydraulic conductivity of each layer (McDonald and Harbaugh, 1988). Vertical and horizontal anisotropy initially were assigned a value of 1 and adjusted as the model was calibrated. This indicates that for initial simulations, the value of horizontal hydraulic conductivity within each aquifer was the same along rows and columns, and was also equal to the value of vertical hydraulic conductivity.

Zones were assigned to hydrogeologic units that had similar hydrologic characteristics (fig. 16) on the basis of the surface expression of the four basic lithologies present in the model area. Zone 1 represented the predominantly sandstone aquifers: Juniata, Bald Eagle, and Tuscarora. Zone 2 represented the predominantly shale aquifers: Reedsville and Waynesboro. Zone 3 represented the mixed carbonate aquifers: Coburn through Loysburg, Bellefonte /Axemann, and the Nittany/Stonehenge. Zone 4 represented the Gatesburg aquifer. Zones for layer 2 were directly below zones for layer 1 (fig. 17).

The value for recharge used for model calibration was obtained from Becher (1996). Becher used a computerized hydrograph-separation program (HYSEP, Sloto and Crouse, 1996) to separate the surface runoff and stream base-flow components for the USGS streamflow-measurement station at Kishacoquillas Creek at Reedsville. Using the fixed-interval method, a value of $13 \mathrm{in}$. of annual base flow discharge was calculated for Kishacoquillas Creek in Mifflin County, Pa. (fig. 1), a stream in a similar setting underlain by carbonate bedrock. Using the assumption that long-term base flow is equivalent to recharge, the value of 13 in. was used in the MODFLOW model for recharge. An alternate value for recharge was estimated for two nearby USGS streamflow-measurement stations using the local-minimum method of hydrograph separation (Sloto and Crouse, 1996). The long-term median base flow for Dunning Creek near Belden in Bedford County, Pa. (fig. 1), from 1940 to 2001 was $9.1 \mathrm{in} / \mathrm{yr}$. The long-term median base flow for Frankstown Branch Juniata River at Williamsburg (Blair County, Pa.) from 1917 to 2001 was 9.7 in/yr. Although Dunning Creek and Frankstown Branch Juniata River are both closer to Martinsburg than Kishacoquillas Creek, Kishacoquillas is geologically more similar to the Martinsburg area. The high percentage of non-carbonate rock in the Dunning Creek and Frankstown Branch Juniata River watersheds would tend to make estimates of base flow in those watersheds lower than would be expected in a watershed with mostly carbonate bedrock. Also, the localminimum method of hydrograph separation is a lower estimate of base-flow discharge (or recharge) than the fixed interval method. Therefore, the value of 13 in. of recharge was used for model calibration, and a value of $9.5 \mathrm{in}$. of recharge was used to simulate the zone of contribution in a sustained dry period.

\section{Model Calibration}

Model calibration is a process by which aquifer properties are adjusted and results of model simulation are compared to observations of water levels and discharge from the aquifer system. The purpose of this is to estimate the optimal hydraulic properties of aquifers and demonstrate the capability of the model to reliably simulate a measured value such as a waterlevel altitude, with the implication that it will then also accurately predict other unmeasurable response such as the zone of contribution to a well. MODFLOW-2000 has the capability to estimate the optimum values for parameters such as recharge, anisotropy, and hydraulic conductivity that minimize the difference between measured and simulated aquifer characteristics (Harbaugh and others, 2000). Only water-level altitude measurements were used for model calibration (table 4). The parameter-estimation process used an iterative method to adjust the values of parameters to minimize the value of a leastsquared objective function that measures how close the numerical model simulates field measurements of water-level altitudes. The process computes parameters that were the most sensitive and caused the largest change in head per change in parameter value. This sensitivity can be used to guide data collection and revise the conceptual model and the numerical model.

A steady-state calibration was conducted to represent average ground-water-flow conditions in the study area. Water levels from 16 wells were used in model calibration. Water levels were measured in 2002 at six wells where water levels were static and suitable for model calibration. To supplement the number of wells with water levels available for model calibration, water levels from wells reported in Becher (1996) also were used (table 4). Streamflow was measured under base-flow conditions, but at an abnormally high base flow, and therefore was not used in model calibration. When streamflow measurements were made, the flow at the nearest USGS streamgage (Frankstown Branch Juniata River) was near the 75th percentile, a value exceeded only 25 percent of all days during the period of record.

Eight parameter values were initially assigned to represent horizontal hydraulic conductivity in each of the four aquifers in the upper and lower layers. Together with recharge, horizontal anisotropy, and vertical anisotropy, the resulting number of parameters (11) was more than could accurately be estimated on the basis of the number of observations. Initial model runs, therefore, were conducted to determine which parameters were most sensitive and could be estimated. Composite sensitivity is calculated as follows: the sensitivities are scaled by multiplying them by the product of the parameter value and the square root of the weight of the observation to obtain dimensionless values. The scaled sensitivities for each parameter are then squared and the sum of these values is divided by the number of observations. The composite scaled sensitivities equal the square root of these values. Sensitivity analysis indicated the model was highly sensitive to recharge; however, using recharge as a parameter caused statistically significant correlations ( 0.99 or higher) among all other parameters suggesting a high probability of a non-unique solution in which an infinite number of combinations of recharge values and hydraulic conductivity values could match the water levels used for calibration. Therefore, 
recharge was assigned a constant value (13.5 in/yr) during model calibration.

The sensitivity analysis also indicated the hydraulic-conductivity values of the upper and lower layers of the sandstone aquifer were the least sensitive parameters in the model, had statistically significant correlations with each other, and were near the same value. The upper and lower sandstone units were combined and simulated as one parameter; this resulted in significant improvements with closer agreement between simulated and measured water levels in the model. The combined sandstone unit was still highly insensitive (fig. 18), indicating it was unlikely to be predicted with any degree of certainty and was specified as $0.33 \mathrm{ft} / \mathrm{d}$, a value obtained from a previous study of ground water in sandstone aquifers (Gburek and others, 1998). Analysis of sensitivity from subsequent model runs indicated the upper and lower shale unit and the upper and lower Gatesburg unit also could be combined, leaving the mixed lime- stone and dolomite aquifers as the only unit simulated with a different hydraulic conductivity in layer 1 and layer 2 . Specifying a value of recharge and the hydraulic conductivity of the sandstone aquifer and combining the upper and lower units into a single parameter left six parameters to estimate: horizontal hydraulic conductivity in four units, vertical anisotropy, and horizontal anisotropy. Among these six parameters, the three most sensitive were the horizontal anisotropy, hydraulic conductivity of the upper limestone and dolomite unit, and the hydraulic conductivity of the lower limestone and dolomite unit (fig 18). Obtaining optimum parameter estimates for these three values resulted in significant improvement of the model. The values of the three remaining parameters, hydraulic conductivity of the shale aquifer, hydraulic conductivity of the dolomite aquifer, and vertical anisotropy, were estimated during the final parameter-estimation run. No correlation greater than 0.85 was found among the six parameters estimated.

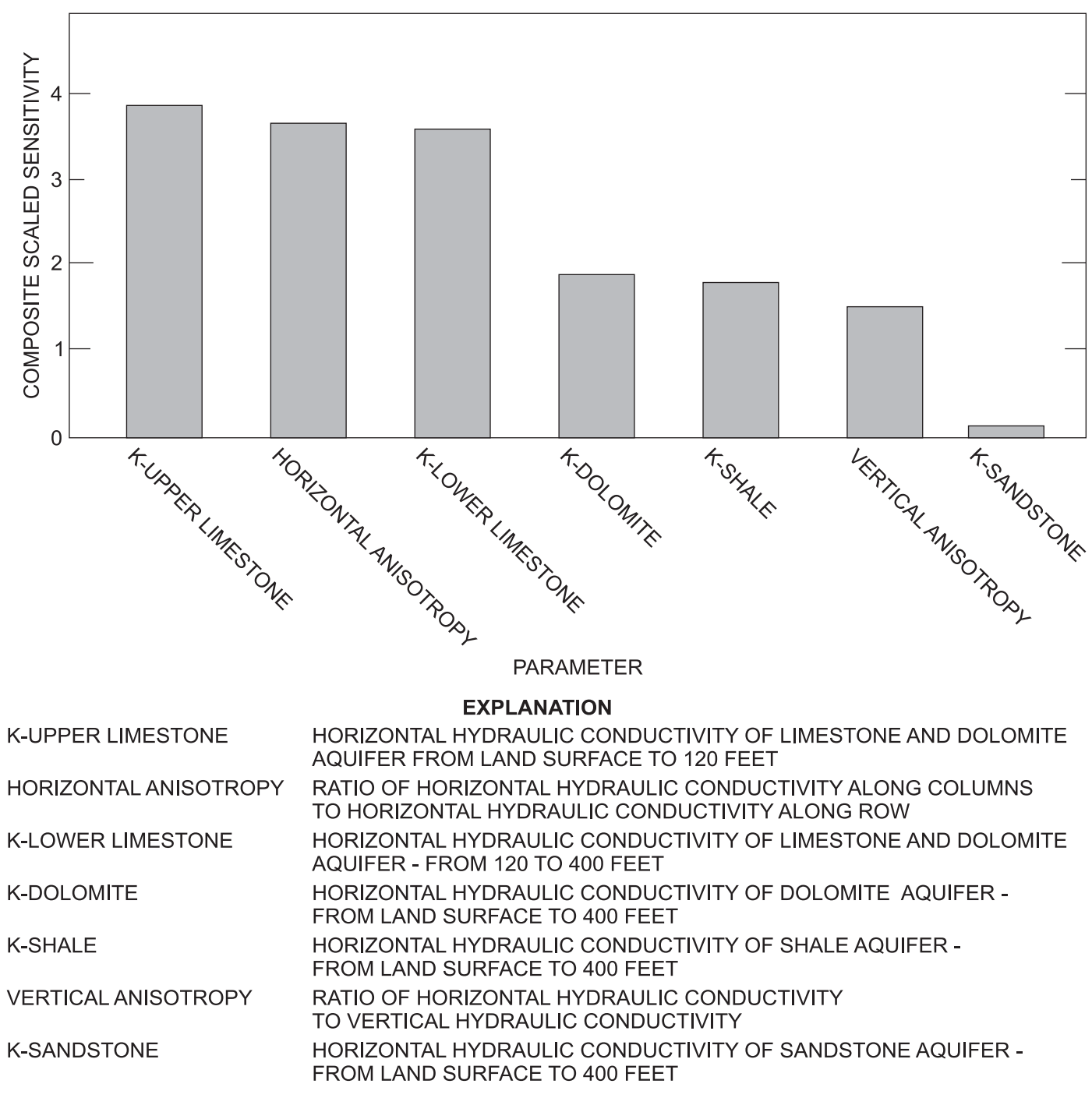

Figure 18. Composite scaled sensitivities (Hill and others, 2000) for parameters used in model calibration. 


\section{Determining Sources of Water and Contaminants to Wells in a Carbonate Aquifer near Martinsburg, Pennsylvania}

Uncertainty of the estimated parameters is related to parameter sensitivity. Those parameters that are highly sensitive usually are estimated with a higher level of confidence than those parameters that are not highly sensitive. The relation between the measured water levels in the 16 wells used to calibrate the model and the simulated water levels in those wells is shown in figure 19 (one of the wells was omitted during calibration because the cell where it was located went dry). Measurements of head were equally weighted during model calibration. Plots of residuals (the difference between the simulated value and the observed value) and weighted simulated equivalents showed no bias in the prediction of heads, and the geographical distribution of the residuals showed no spatial pattern. Three streamflow measurements were available within the area of the ground-water model boundary. Streamflow measurements were not used for actual calibration; however, the values are given here for comparison purposes. The measured streamflows at Piney Creek and the Unnamed Tributary to Clover Creek were very small $\left(0.1 \mathrm{ft}^{3} / \mathrm{s}\right)$, even when measured under the high baseflow conditions, and the simulated streamflows were 0.20 and $0.08 \mathrm{ft}^{3} / \mathrm{s}$, respectively. In absolute terms, the measured and simulated values were quite close; however, in relative terms, the error was 100 and 20 percent, respectively. The discharge measured at Cove Creek was $6.75 \mathrm{ft}^{3} / \mathrm{s}$, and the simulated equivalent streamflow was $3.44 \mathrm{ft}^{3} / \mathrm{s}$.

\section{Simulation Results and Sensitivity}

Measures of model results given herein are numerical indications of the level of confidence in the properties estimated. Final calibrated parameter values are shown in table 10. One important measure of the model fit is the sum of squared residuals, which is based on the fit between measured and simulated head. For this regression, the sum of squared residuals was 76.2. The root-mean-square error for the simulation was $2.2 \mathrm{ft}$. The largest positive residual value (simulated minus measured) was $19 \mathrm{ft}$ (BA 437), and the most negative residual value was $-10 \mathrm{ft}$ (BA 549) (fig. 19).

The values given on table 10 are based on the assumption that the optimization model is linear; therefore, if the model is highly non-linear, these statistics are not reliable. One measure of model linearity is the correlation between weighted residuals and normal order statistics, which, for this model, was 0.94 . This indicated a 90-percent probability that the weighted residuals were independent and normally distributed. Beale's measure of linearity (Hill and others, 2000) was 0.73, a value higher than the threshold for this model of 0.31 indicating that the model regression was moderately non-linear. Therefore, the confidence intervals shown on table 10 based on linear theory are considered approximate values.

The RESAN program (Hill and others, 2000) was used to calculate Cook's D and DFBeta statistics, which indicated the influence of individual observations on the estimated parameter values. These statistics indicated that heads in wells BA 248, BA 548, BA 544, and BA 543 were the observations that had

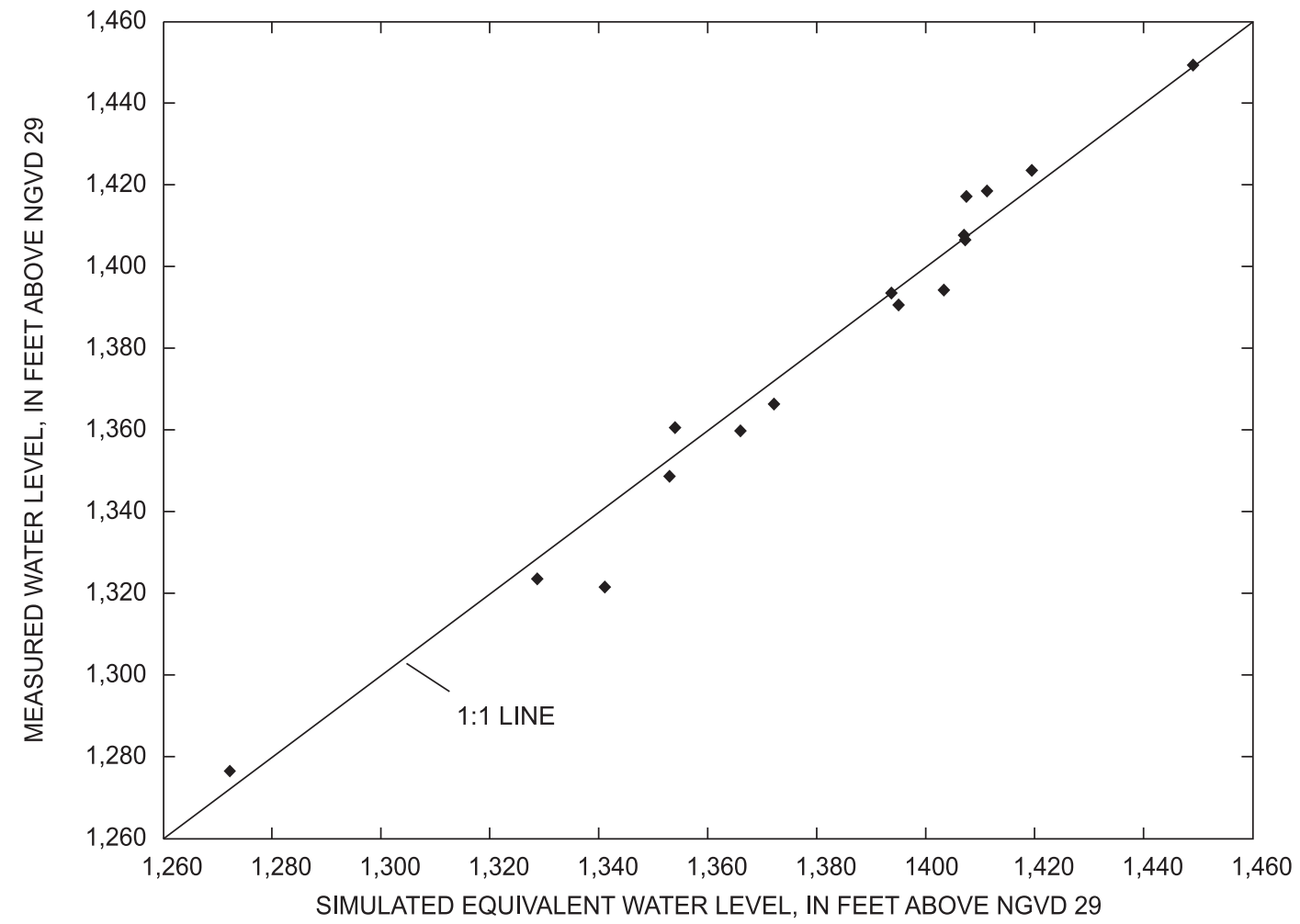

Figure 19. Calibration results showing simulated and measured water levels near Martinsburg, Pennsylvania. 
Table 10. Optimum values of aquifer properties estimated near Martinsburg, Pennsylvania.

[n/a, value not computed; $\mathrm{ft} / \mathrm{d}$, feet per day]

\begin{tabular}{|c|c|c|c|c|c|}
\hline & Property & Layer & $\begin{array}{c}\text { Zone } \\
\text { (fig. 16) }\end{array}$ & $\begin{array}{l}\text { Final value } \\
\text { (ft/d) }\end{array}$ & $\begin{array}{c}\text { Approximate } \\
\text { 95-percent } \\
\text { confidence } \\
\text { interval }^{1}\end{array}$ \\
\hline \multirow{5}{*}{$\begin{array}{l}\text { Horizontal hydraulic } \\
\text { conductivity of: }\end{array}$} & Sandstone aquifer & 1 and 2 & 1 & 0.33 & $\mathrm{n} / \mathrm{a}$ \\
\hline & Shale aquifer & 1 and 2 & 2 & .15 & $0.02-0.39$ \\
\hline & Upper limestone / dolomite aquifer & 1 & 3 & .6 & $.2-1.9$ \\
\hline & Lower limestone/ dolomite aquifer & 2 & 3 & 1.2 & $.2-2.3$ \\
\hline & Gatesburg aquifer & 1 and 2 & 4 & 35.7 & $10.2-125$ \\
\hline \multirow[t]{2}{*}{ Anisotropy } & $\begin{array}{l}\text { Horizontal (hydraulic conductivity } \\
\text { along model columns/ hydraulic } \\
\text { conductivity along model rows) }\end{array}$ & 1 and 2 & All & 5.3 & $1.8-15.8$ \\
\hline & Vertical & 1 and 2 & All & 24.4 & $2.3-259$ \\
\hline
\end{tabular}

${ }^{1}$ Values are given as approximate ranges because the model is moderately non-linear.

the most influence on the estimated parameter values. The purpose of these measures were 1) to ensure data were accurate for those observations having the most influence on the model results, and 2) to see if there were spatial patterns in the distribution of these observation wells. The accuracy of the input data from each of these wells was verified, and no spatial patterns were evident from the geographical distribution of the most influential wells.

The water budget determined by simulation of groundwater flow indicated quantities of flow for the various components of the ground-water system. All inflow to the system was recharge from precipitation (table 11), as previously discussed. The outflow was distributed among discharge to streams (drains), underflow (constant-head boundaries), and ground- water pumpage (wells). The vast majority of the water (75 percent) discharged to the drains within the ground-water model boundary. An additional 22 percent of the water discharged through constant-head boundaries, representing ground water that traveled under the ground-water model boundary and moved toward Clover Creek to the east. The amount pumped from the municipal-supply wells was about 3 percent of the total water budget for the area simulated. About 45 percent of the water traveled into the deeper parts (layer 2) of the groundwater system (fig. 20) where some water was withdrawn from the municipal wells and the remainder eventually returned to layer 1 to discharge at the streams or exit the system as underflow.

Table 11. Water budget for steady-state simulation near Martinsburg, Pennsylvania.

[ $\mathrm{ft}^{3} / \mathrm{d}$, cubic feet per day; $\mathrm{ft}^{3} / \mathrm{s}$, cubic feet per second]

\begin{tabular}{|c|c|c|c|c|c|}
\hline $\begin{array}{c}\text { Source of inflow } \\
\text { to model }\end{array}$ & $\begin{array}{l}\text { Inflow volume } \\
\left(\text { million } \mathrm{ft}^{3} / \mathrm{d}\right)\end{array}$ & $\begin{array}{c}\text { Inflow volume } \\
\left(\mathrm{ft}^{3} / \mathrm{s}\right)\end{array}$ & $\begin{array}{l}\text { Source of outflow } \\
\text { from model }\end{array}$ & $\begin{array}{l}\text { Outflow volume } \\
\left(\text { million } \mathrm{ft}^{3} / \mathrm{d}\right)\end{array}$ & $\begin{array}{l}\text { Outflow volume } \\
\qquad\left(\mathrm{ft}^{3} / \mathrm{s}\right)\end{array}$ \\
\hline \multirow[t]{2}{*}{ Recharge (precipitation) } & 1.17 & 13.59 & Discharge to streams & 0.88 & 10.17 \\
\hline & & & Ground-water pumpage & .04 & .46 \\
\hline TOTAL INFLOW & 1.17 & 13.59 & TOTAL OUTFLOW & 1.18 & 13.59 \\
\hline
\end{tabular}




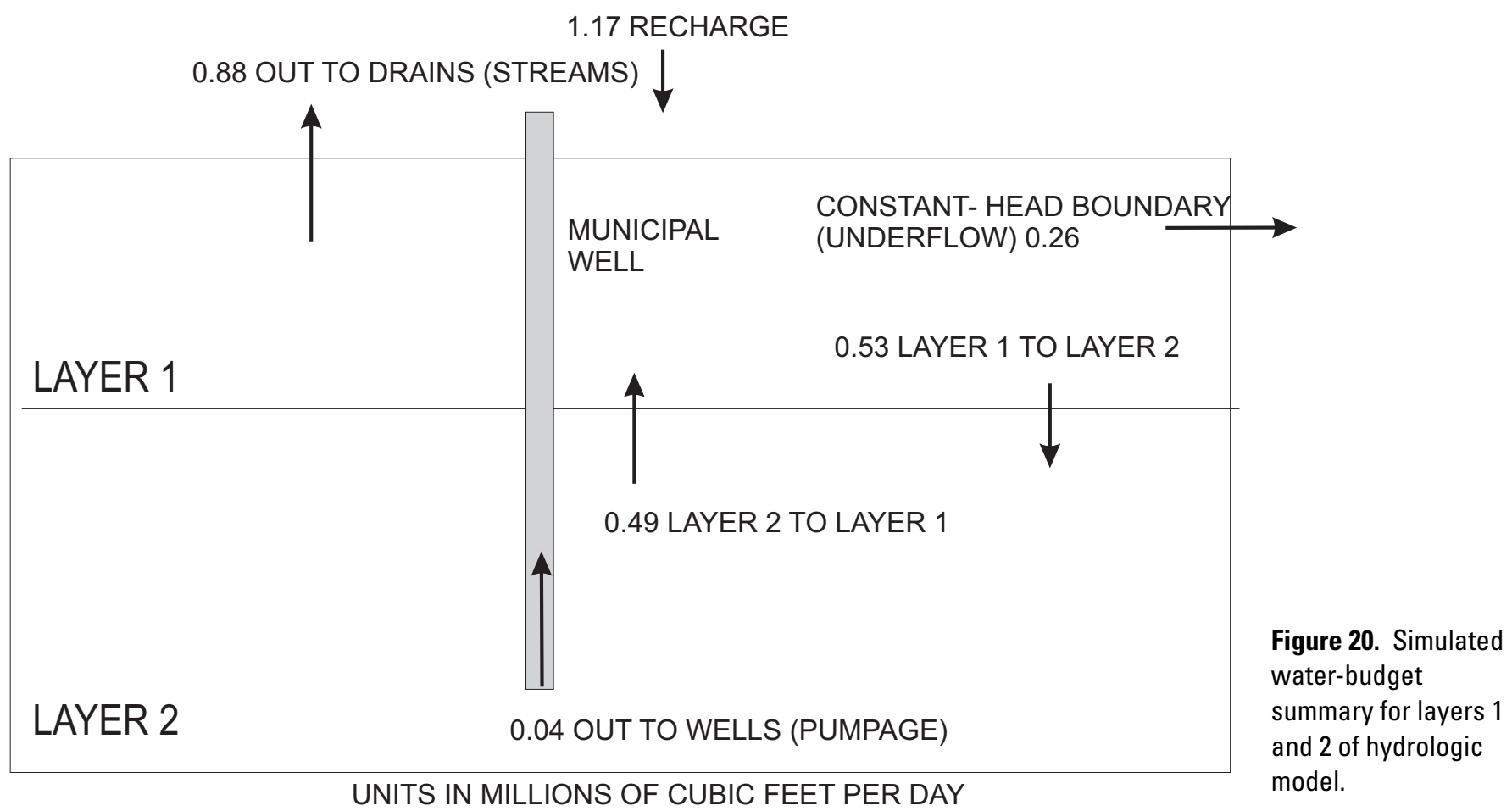

\section{Zone of Contribution to Municipal Wells}

The simulated areal extent of the zone of contribution for well BA 545 in the Wineland Well Field and well BA 332 in the Hershberger Well Field combined is shown in figure 21. Also shown in figure 21 is the simulated water table. The simulated water table can be compared to the water table based on waterlevel measurements from Becher (1996) in figure 9. The simulation was conducted with both wells pumping full time at halfcapacity (each pumping 150,000 gal/d simultaneously).

Ground-water flow not captured by pumping discharges to local streams.

The simulation showed the ground-water table did not necessarily mirror surface topography. For example, there were three topographic high areas near the Wineland Well Field. The upgradient directions topographically were to the northeast, west toward the Borough of Martinsburg, and to the south. The water-level contours from Becher (1996) and the simulated water levels showed a regional gradient of the water levels causing the ground-water-flow direction to be from the south and west to both well fields. The simulated flow lines nearly parallel to the strike of the fold axis (fig. 22) were a result of the approximate 5 to 1 anisotropy (table 10) estimated by the regression, which physically represented that hydraulic conductivity in the ' $y$ ' direction (along model columns) in the model was five times higher than hydraulic conductivity in the ' $x$ ' direction (along rows) so the majority of the flow to both well fields was from the south (figs. 22 and 23). Fractures at the intersection of bedding and cleavage planes oriented in this direction may have been the cause of the anisotropy. The deep, relatively flat water table in the Gatesburg subcrop area illustrated in figure 24 was one of the factors influencing the ground-water-flow field. The deep water table underlying the Gatesburg aquifer has been documented in previous studies (Becher, 1996; Chin, 1996) suggesting that the topographic high area underlain by the Gatesburg aquifer did not influence the direction of ground-water flow. Instead, water passed from west to east under the topographic high area of the Gatesburg aquifer and likely discharged to Clover Creek, which is situated on the topographically low part of the valley in this area and acts as a regional drain for the system.

Several model simulations were conducted to determine the affect of changing parameter values on the zone of contribution. The areal extent of the zone of contribution that may be expected under low recharge conditions, lowering recharge from 13 to $9.5 \mathrm{in} / \mathrm{yr}$, is illustrated in fig. 22. Note the larger areal extent of the zone of contribution predicted when the lower recharge value is used compared to when the normal recharge (steady-state conditions) is used. The sum of squared residuals for this simulation was 486 . Simulations also were run with no horizontal anisotropy, which resulted in a sum of squared residuals of 837. The zone of contribution in this scenario was only slightly different than that using the calibrated value of horizontal anisotropy (fig. 25). A simulation with no vertical anisotropy resulted in a sum of squared residuals of 576, but the zone of contribution was virtually identical to that shown in figure 21 . Model sections were evaluated for each of these scenarios and showed only minor differences in the water table from that illustrated in figures 23 and 24 . 


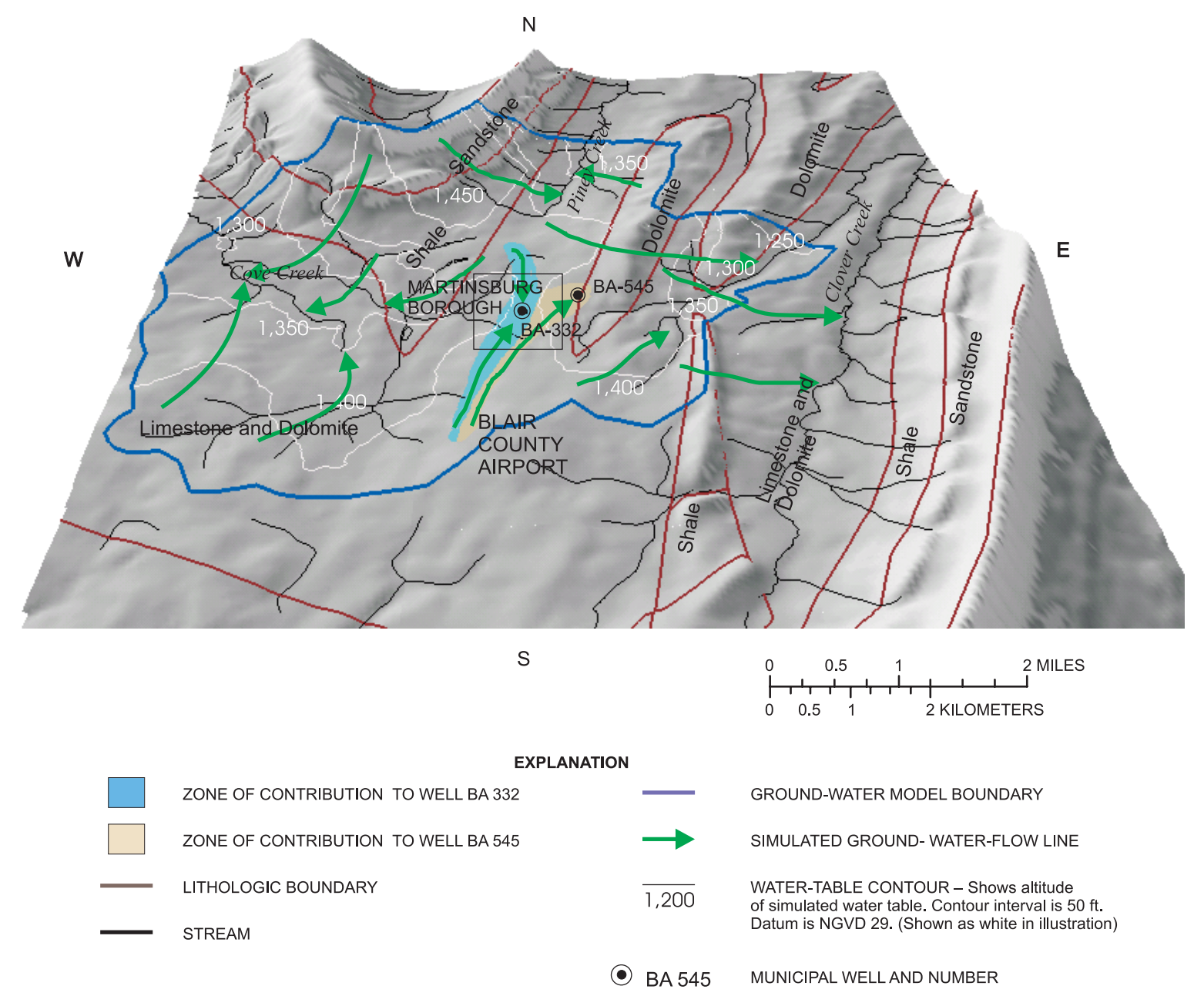

Figure 21. Simulated water table and zone of contribution to wells near Martinsburg, Pennsylvania (vertical exaggeration X 3 ). 


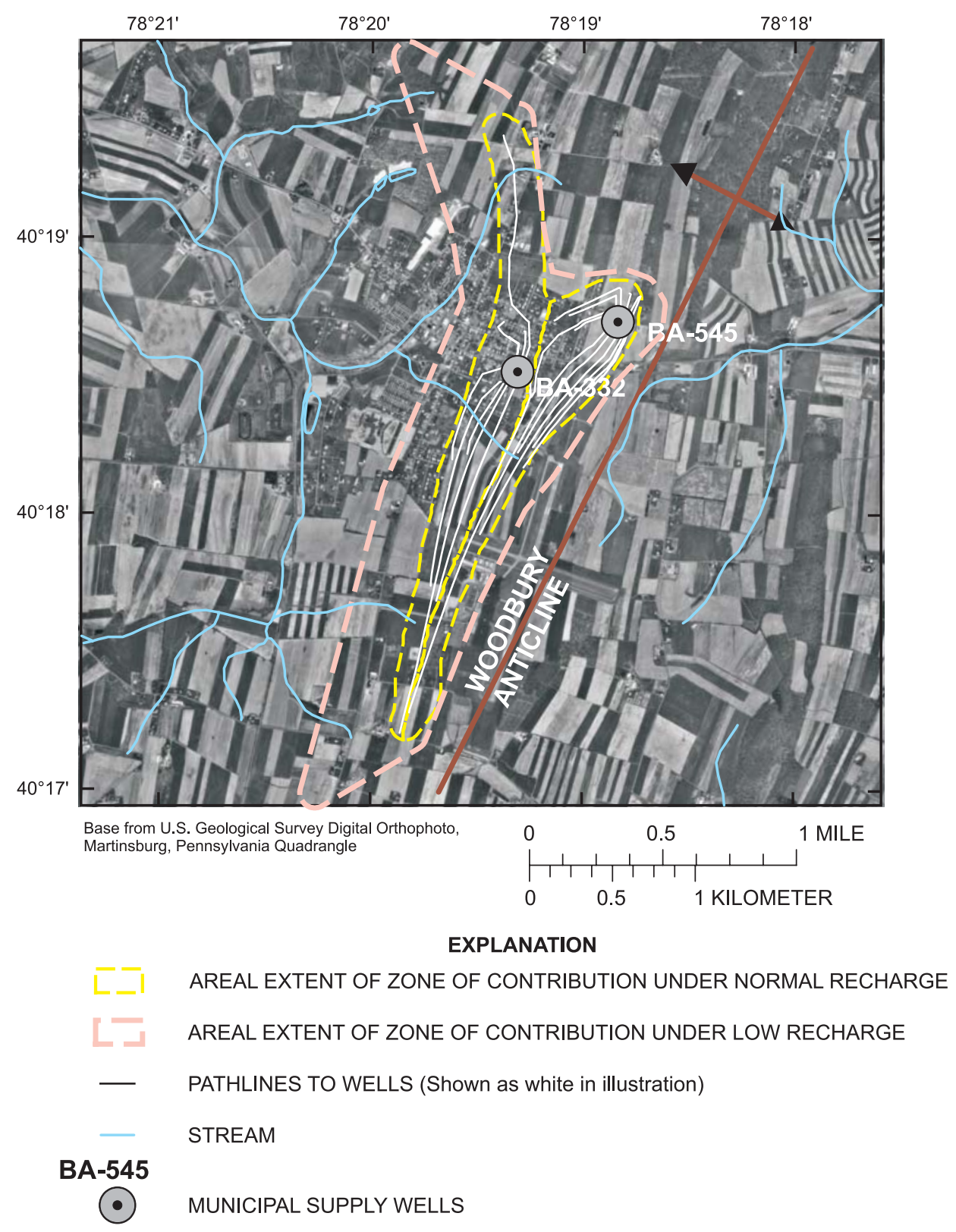

Figure 22. Areal extent of zone of contribution to wells, pathlines, and source areas near Martinsburg, Pennsylvania, under normal and low recharge conditions. Dividing line between zones is approximate, actual boundaries overlap. 


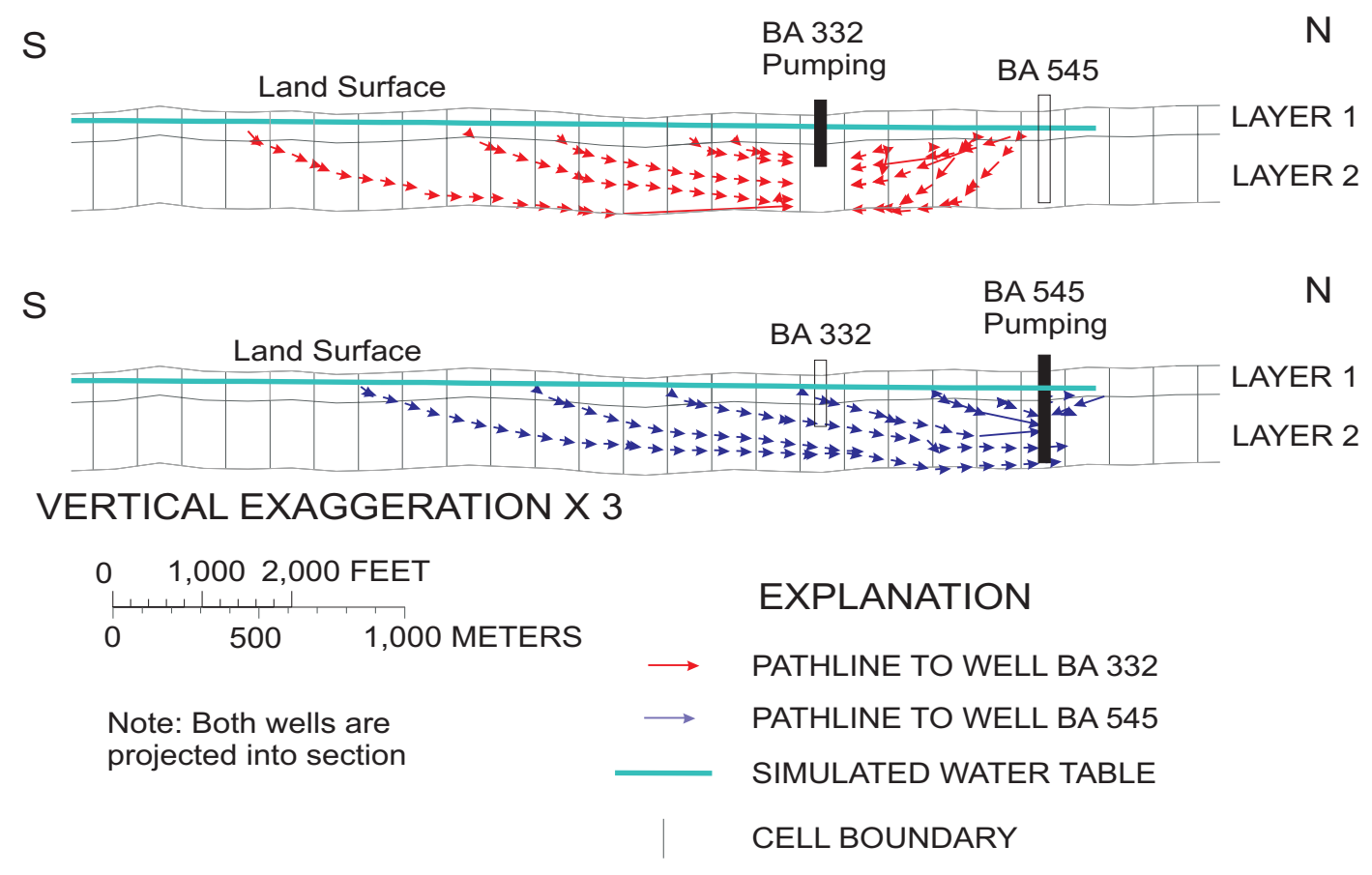

Figure 23. Simulated water table and pathlines to municipal wells from south to north along model column 33 (location of model column shown on figure 16).

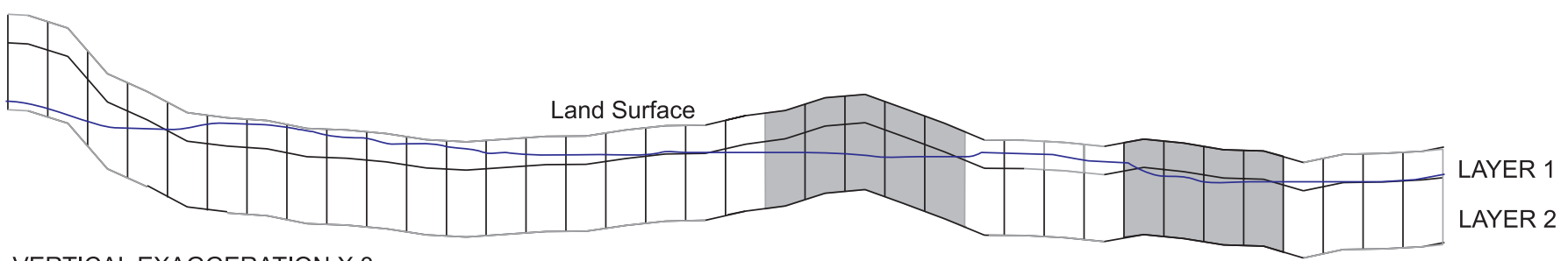

VERTICAL EXAGGERATION X 3

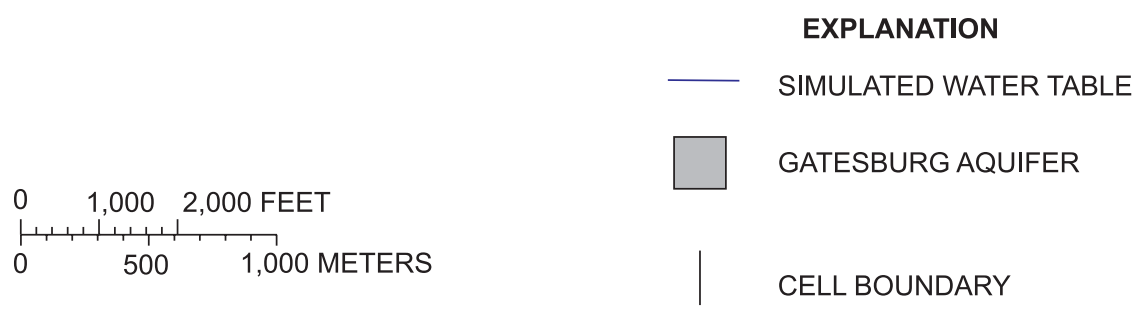

Figure 24. Simulated water table from west to east along model row 20 (location of model row shown on figure 16). 


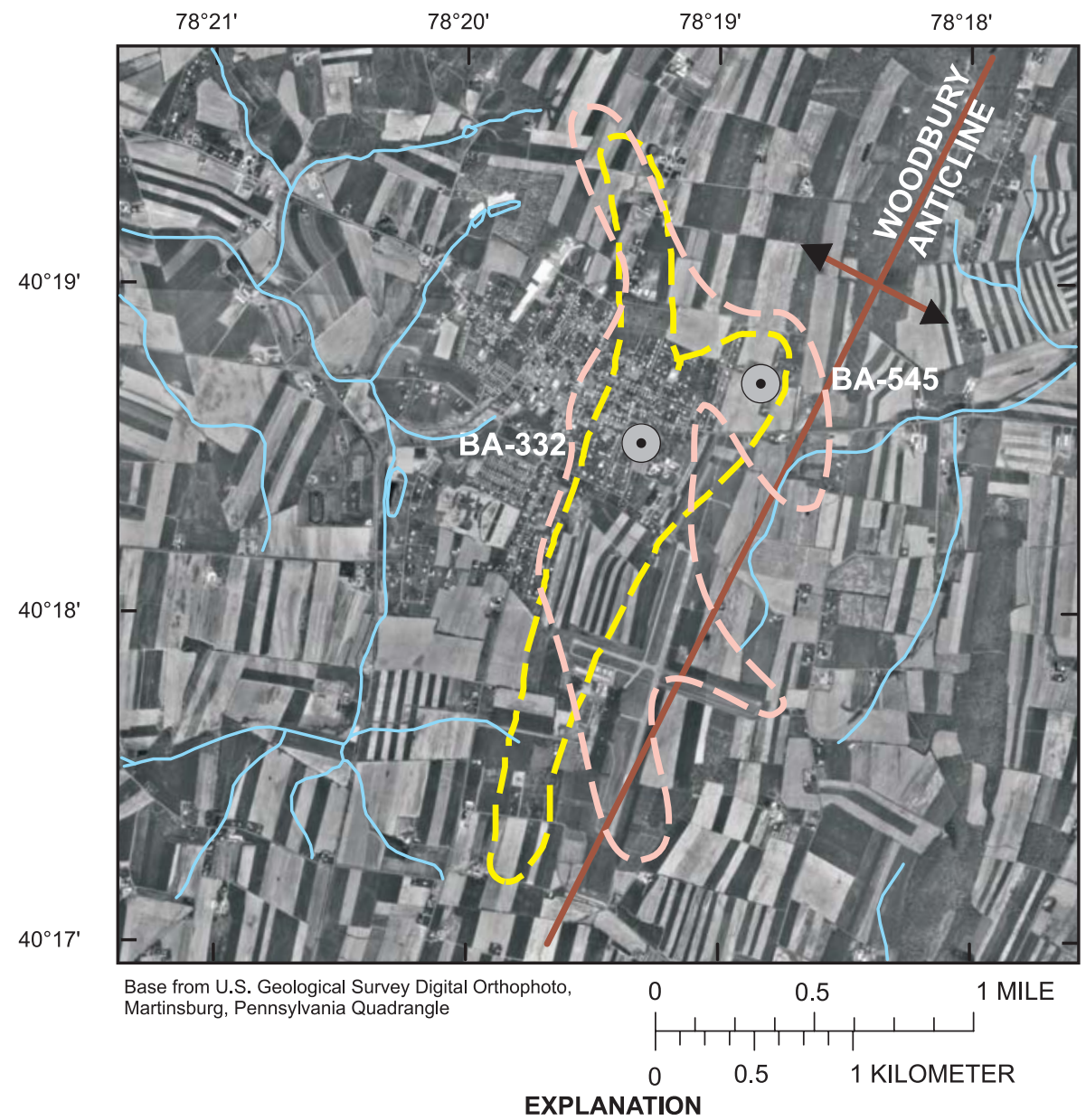

AREAL EXTENT OF ZONE OF CONTRIBUTION USING CALIBRATED VALUE OF ANISOTROPY APPROXIMATELY $(5: 1)$ AREAL EXTENT OF ZONE OF CONTRIBUTION WITHOUT ANISOTROPY STREAM

- MUNICIPAL SUPPLY WELLS

Figure 25. Areal extent of zone of contribution to wells near Martinsburg, Pennsylvania, illustrating simulation with horizontal anisotropy and without horizontal anisotropy. 


\section{Relating Simulation Results, Natural Geochemistry, and Anthropogenic Contaminants to Determine Source Areas}

Simulation results from the MODFLOW model indicated the areal extent of the zone of contribution to wells BA 545 and BA 332. Water-quality sampling was used to classify the samples as having sources in limestone aquifers or dolomite aquifers. As previously stated, the Gatesburg aquifer is predominantly dolomite, the Nittany/Stonehenge and the Bellefonte/ Axemann aquifers are mixed limestone and dolomite aquifers, and the Coburn through Loysburg aquifer is predominantly limestone. The modeling and geochemical approaches can be combined to determine whether or not the findings are in accordance with each other.

The simulation results from the MODFLOW model indicated the areal extent of the zone of contribution for the source of water to well BA 545 included a combination of the Gatesburg, Nittany/Stonehenge, Bellefonte/Axemann, and Coburn through Loysburg aquifers (fig. 26). Although the well was completed in the Gatesburg aquifer, the areal extent of the zone of contribution was not restricted to that aquifer. Well BA 332 is completed in the Nittany/Stonehenge aquifer, and the areal extent of the zone of contribution included part of the Nittany/ Stonehenge, Gatesburg, Bellefonte/Axemann, and Coburn through Loysburg aquifers (fig. 26). The majority of the zone of contribution was within the Nittany/Stonehenge aquifer. Results of geochemical analysis of water from well BA 545 and BA 332 indicated water from a dolomite and a mixed limestone and dolomite aquifer, respectively, which agreed with the results of the MODFLOW model.

The relation of karst features to the areal extent of the zones of contribution is illustrated in figure 26 . The model did not account for the potential changes in hydraulic characteristics of ground-water flow caused by these features, such as high volumes of rapid recharge through closed depressions or sinks and high hydraulic conductivity along fracture traces. The actual effects of these features is unknown. It is important to note, however, that some of these features were in the areal extent of the zone of contribution to the wells. Although the geochemical results and MPA did not indicate conduit flow or direct recharge through karst features, the Martinsburg Borough Authority may want to consider the closed depressions in or near the areal extent of the zone of contribution to the well to be potential points of entry of contaminants to the aquifer by virtue of their proximity to the municipal supply wells. The closed depressions within and just to the north of the Wineland Well Field (BA 545) are probably the most likely to have an immediate and direct effect on the wells.

Potential anthropogenic contaminants in the wells of interest also can be compared to the results of the MODFLOW model. Human activity at the land surface in the areal extent of the zone of contribution to a well is, by definition, the source of anthropogenic contaminants to wells. The primary contaminant of concern for these wells is nitrate. The analysis of land use, nitrate concentrations, nitrogen isotopes, and other contaminants indicated the following: 1) the primary source of the nitrate in the municipal supply wells was from agricultural activity, and 2) the source of the nitrate in the municipal supply wells was predominantly chemical fertilizer in well BA 545 and a mixture of chemical fertilizer and manure in well BA 332.

Land use in the areal extent of the zone of contribution to wells BA 545 and BA 332 is shown in figure 27. The areal extent of the zone of contribution to well BA 545 included urban land use in the Borough of Martinsburg; however, the areal extent of the zone of contribution had a large amount of agricultural land use, both to the north and southeast of Martinsburg (fig. 27). Approximately 82 percent of the land use in the areal extent of the zone of contribution to well BA 545 was agricultural, 12 percent was urban, and the remaining 6 percent was forested land use. The areal extent of the zone of contribution to well BA 332 included 81 percent agricultural land use, 18 percent urban land use, and 1 percent forested land use (fig. 27).

In the areas where the land use was agricultural, the nitrate sources were chemical fertilizer and manure. There were several potential sources in residential areas. Almost all residences in the areal extent of the zone of contribution were served by public sewer. In those areas, the potential sources of nitrate to ground water were limited to home lawn-care fertilizer or possibly leaking sewer lines. The amount of this input was unknown. In those residential areas not on public sewer (fig. 6), septic systems may have been a source of nitrate as well; however, there are very few of these residences in the areal extent of the zone of contribution. The zone of contribution to both wells contained about 30 homes using on-lot septic systems; however, a nitrogen mass-balance calculation indicates that septic systems could not be the source of most of the nitrogen. Using equation (1) and values from Miller (1980) for nitrogen production from septic systems (effluent concentration of $85 \mathrm{mg} / \mathrm{L}$ of nitrogen and effluent volume of $45 \mathrm{gal} / \mathrm{d}$ per person) and assuming 4 persons per household, the maximum concentration in water in the zone of contribution would be $1.5 \mathrm{mg} / \mathrm{L}$ if septic systems were the only nitrogen source. This estimate assumes that 100 percent of the nitrogen generated in these homes leached into the ground water, allowing no losses to biological processes, septic system pumpage, plant uptake, or any other loss. In reality, many processes affect nitrogen in septic systems; therefore, the contribution of septic system-nitrogen to the municipal-supply wells likely is even lower than the value calculated. The concentrations of nitrate in water samples from wells BA 545 and BA 332 were 8.9 and $9.1 \mathrm{mg} / \mathrm{L}$, respectively, suggesting a large contribution of nitrogen from sources other than septic systems.

The results of water-quality sampling in the municipal supply wells can be compared to the sources of nitrogen in the areal extent of the zone of contribution. Well BA 332 had a $\delta^{15} \mathrm{~N}$ ratio of 6.0 per mil, and well BA 545 had a $\delta^{15} \mathrm{~N}$ ratio of 4.1 per mil. The higher value in well BA 332 is at the high end of the range for chemical fertilizer $(+2$ to +6 per mil) and could include an influence of animal manure $(+10$ to +20 per mil). 


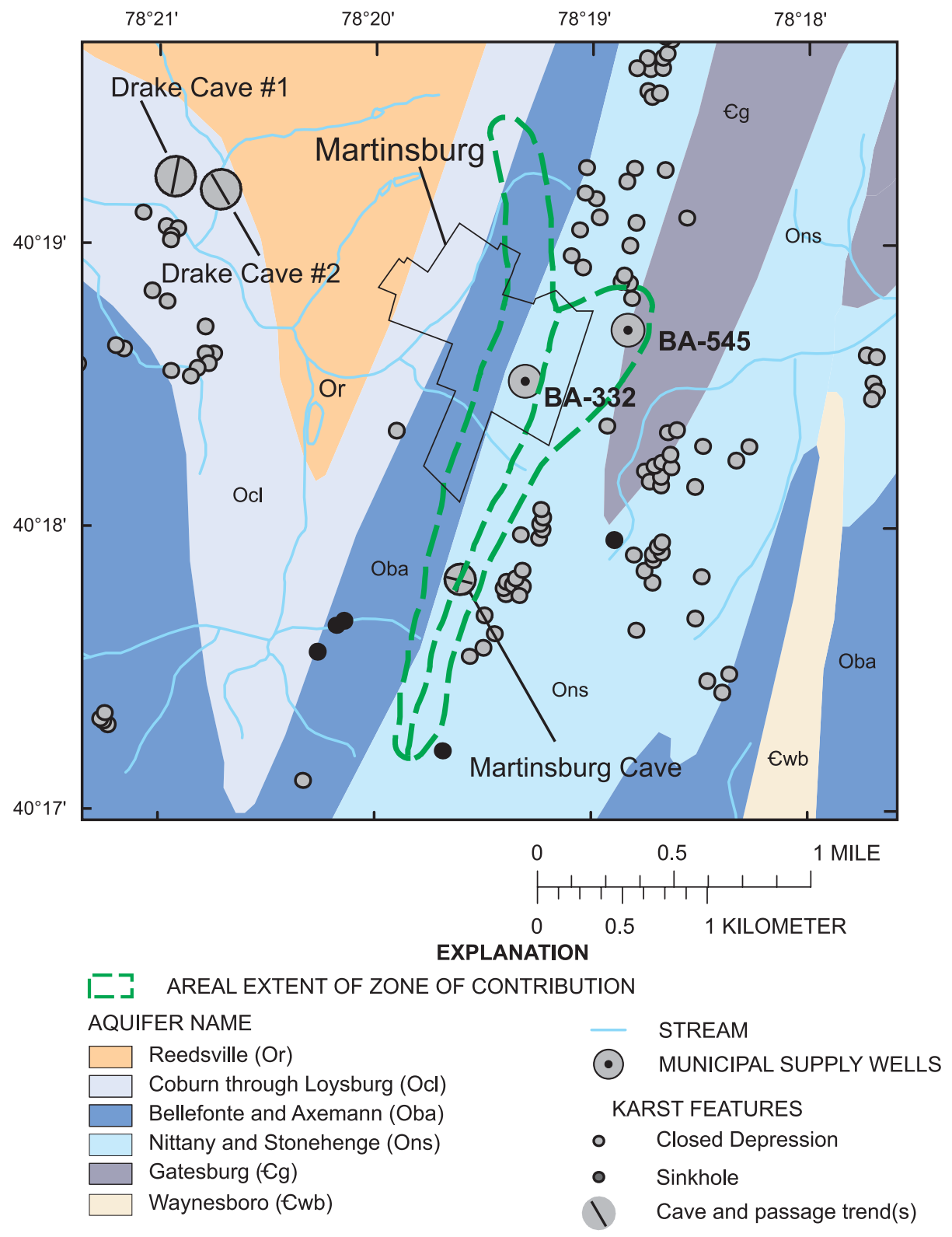

Figure 26. Geology and karst features in the areal extent of the zone of contribution to well BA 332 and well BA 545 near Martinsburg, Pennsylvania. 


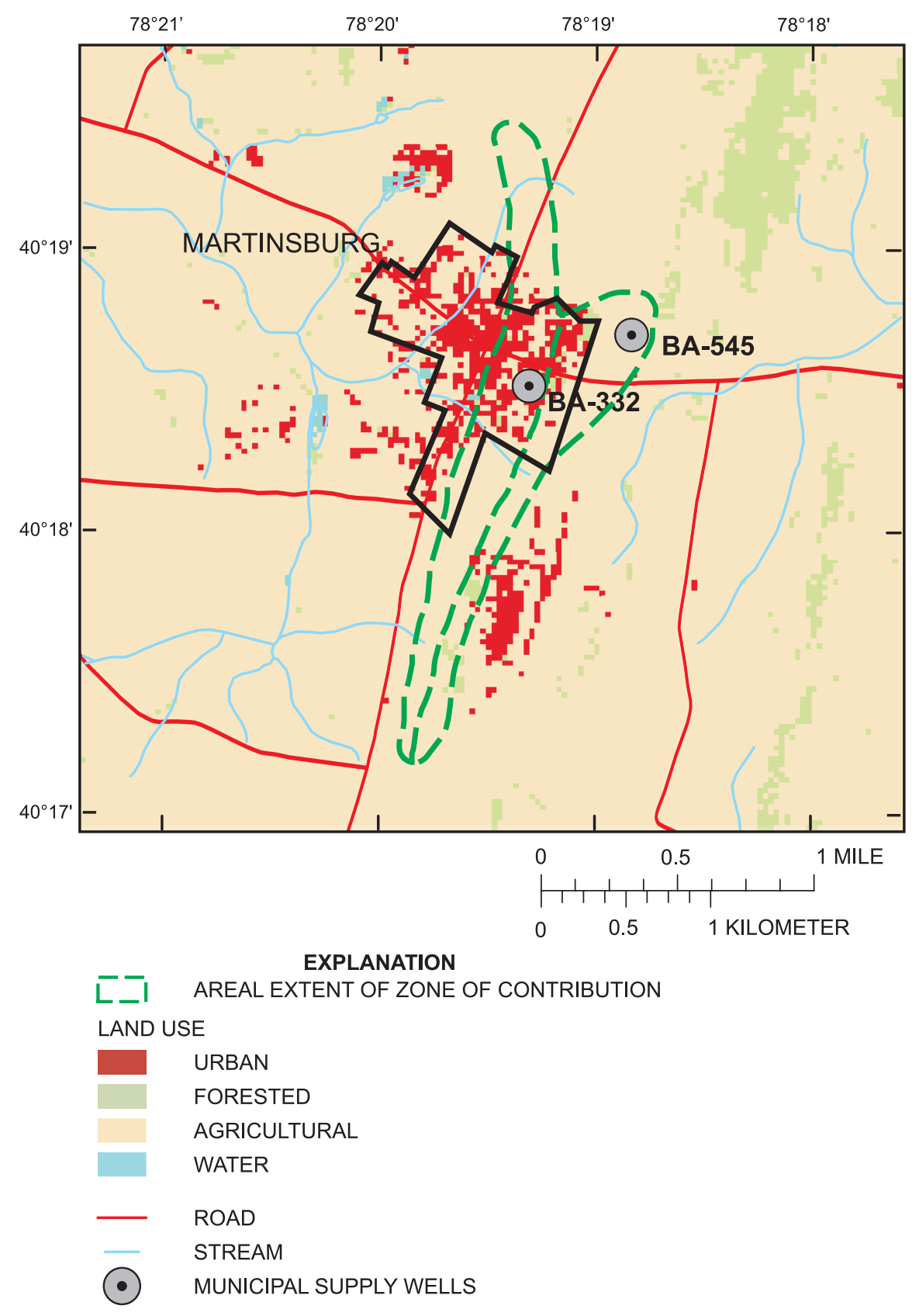

Figure 27. Land use in the areal extent of the zone of contribution to well BA 332 and BA 545 near Martinsburg, Pennsylvania. 


\section{Determining Sources of Water and Contaminants to Wells in a Carbonate Aquifer near Martinsburg, Pennsylvania}

The value in well BA 545 indicated the source of nitrogen in water from the wells was likely to be a result of chemical fertilizer. Because the $\delta^{15} \mathrm{~N}$ ratio values resulting from various sources of nitrogen are represented by ranges rather than a single value, it is not possible to use a mixing model to determine the percentage of water from a given source with any amount of accuracy. For example, using the median $\delta^{15} \mathrm{~N}$ ratio values from Cravotta (1997) of 4 per mil for runoff from fertilizer and 8 per mil for runoff from manure, a binary mixture of water with an equal component from each source would be near 6 per mil; however, there are numerous other combinations of source waters with other $\delta^{15} \mathrm{~N}$ concentrations that could result in that same value. Therefore, individual measurements of $\delta^{15} \mathrm{~N}$ that are in the area where there is overlap in the signature of the sources cannot be used to make conclusive statements about which source is predominant.

The type of nitrogen applied in the areal extent of the zone of contribution to wells BA 332 and BA 545 probably relates to the source of nitrate in ground water. In the areal extent of the zone of contribution to well BA 545, nearly half the agricultural land can be classified with respect to the type of nitrogen applied (fig. 28). In this part of the zone of contribution, 31 percent had chemical fertilizer as the predominate nitrogen source and 46 percent had manure as the predominant nitrogen source; the remaining area had a mixture of chemical fertilizer and manure as the nitrogen source. The areas immediately around well BA 545 have a number of karst features and were the areas where chemical fertilizer was used (fig. 26). Areas that have predominantly animal manure were at the farthest extent of the zone of contribution. About 60 percent of the agricultural fields in the areal extent of the zone of contribution to well BA 332 could be classified with respect to nitrogen source, and all these fields had manure as the predominant source of nitrogen (fig. 28). The urban/residential area in the zone of contribution to both wells underlying the Borough of Martinsburg was likely to have chemical fertilizer as the predominant nitrogen source. Neither municipal well had sufficient numbers of fecal coliform bacteria to do the ARP analysis, but well BA 332 had a higher count of bacteria. Well BA 332 consistently had detectable concentrations of bacteria in samples collected by Martinsburg Borough during routine sampling, whereas the samples collected in well BA 545 rarely had bacteria detected (Randy Stoltz, Martinsburg Borough, written commun., 2002). This seemed to indicate a higher likelihood that water from well BA 332 was affected by animal manure and water from well BA 545 was affected by chemical fertilizer.

Another way to help determine whether human sewage is a possible source of contaminants to the municipal wells is to compare some of the contaminants measured in the municipal wells to values of those contaminants measured downstream from the wastewater treatment plant. In the sample collected downstream from the wastewater treatment plant, 20 of the 63 compounds on the wastewater analysis schedule were detected; whereas only 1 of these compounds was detected in well BA 545 and 4 were detected in well BA 332. The boron concentration downstream from the wastewater treatment plant was $220 \mu \mathrm{g} / \mathrm{L}$, as compared to $20 \mu \mathrm{g} / \mathrm{L}$ in both BA 545 and BA 332. The specific conductance was over $1,300 \mu \mathrm{S} / \mathrm{cm}$ downstream from the wastewater treatment plant; in wells BA 545 and BA 332, the specific conductance was $469 \mu \mathrm{S} / \mathrm{cm}$ and $557 \mu \mathrm{S} / \mathrm{cm}$, respectively. The $\delta^{15} \mathrm{~N}$ ratio was about 11 per mil downstream from the sewage treatment plant; in wells BA 545 and BA 332, the $\delta^{15} \mathrm{~N}$ ratio was 4.0 and 6.1 per mil, respectively. All these factors indicate human sewage was the least likely major source of nitrogen in wells BA 332 and BA 545.

\section{Limitations of Data and Findings}

The findings herein are limited by the assumptions that were made in the ground-water model and the amount of data available to make interpretations. The model was designed with a $490-\mathrm{ft}$ by 490 -ft grid, which provides information on groundwater flow at a large scale. The accuracy of the model in determining water levels and the areal extent of the zone of contribution could be improved by a model with a finer grid. Model input parameters, such as horizontal and vertical hydraulic conductivity and recharge, are applied as an average value for each cell. This assumption of uniformity introduces inaccuracies because of the heterogeneity of the geologic materials and variability of climatic conditions. The model also was created for steady-state conditions, which assume that inflows equal outflows. If the water levels were rising or falling during the time period when the measurements were taken, this would introduce error into the model as well. As previously stated, the MODFLOW model is made for a porous medium. The assumption that the fracture system was equivalent to a porous medium is another potential source of error.

The confidence level associated with the findings could be improved by additional data. The ground-water model could be improved by additional water levels, water levels measured under various hydrologic conditions, as well as additional streamflow measurements to calibrate the model to stream discharge. Aquifer tests could be conducted to improve the parameters estimated by the model and test theories such as the anisotropy indicated by the ground-water model. The significance of the karst features, including the locations of major fracture traces or conduits, and their potential affect on water quality in the municipal wells could be tested by dye-tracer tests or geophysical investigations. Findings based on a single chemical or microbiological analysis could be strengthened by additional sampling. In particular, additional $\delta^{15} \mathrm{~N}$ sampling and ARP analysis could be conducted to clarify the important issue of the sources of nitrogen to the municipal wells. 


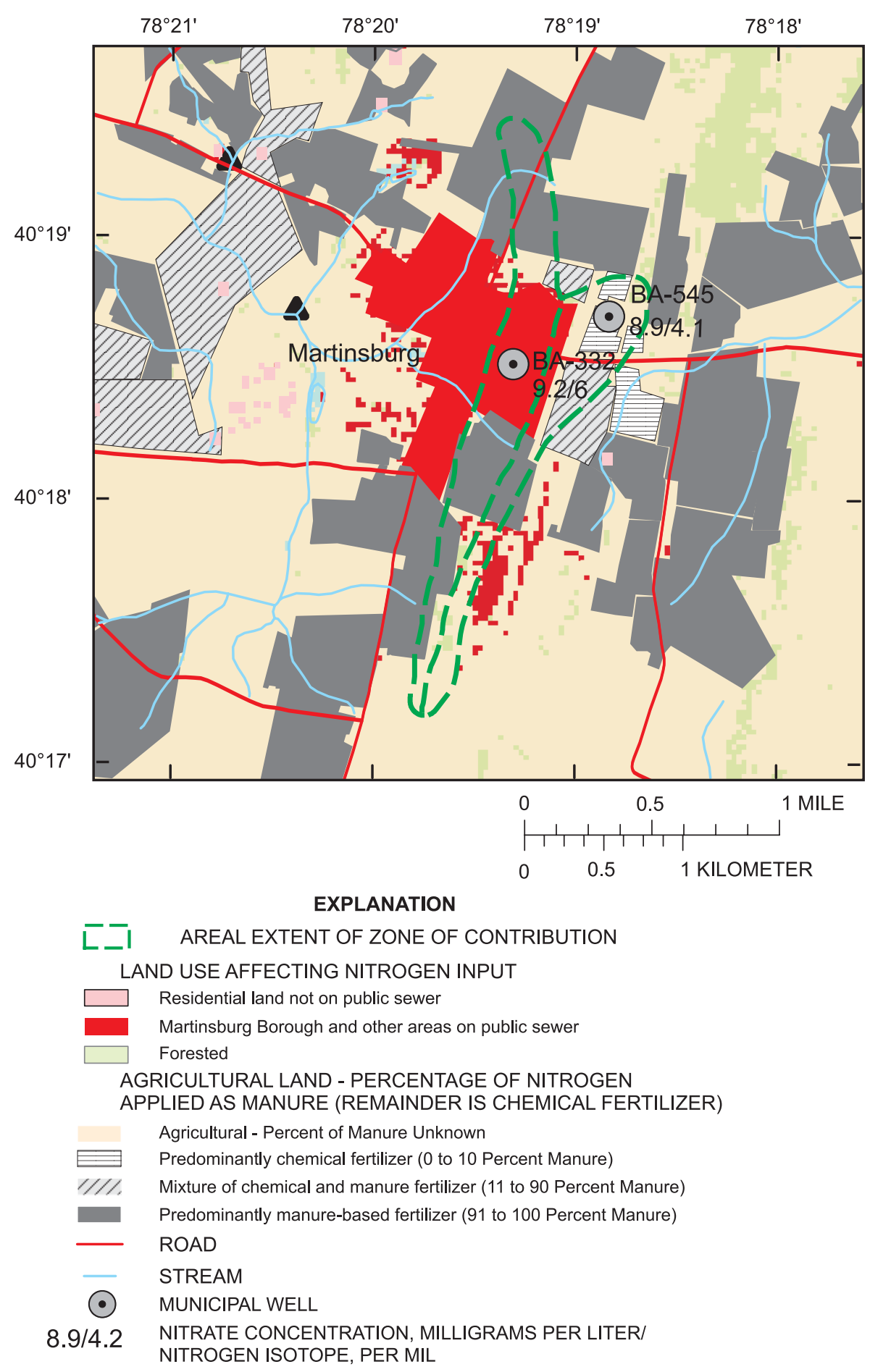

Figure 28. Sources of nitrogen, nitrate concentration, and $\delta^{15} \mathrm{~N}$ in municipal wells near Martinsburg, Pennsylvania. 


\section{Determining Sources of Water and Contaminants to Wells in a Carbonate Aquifer near Martinsburg, Pennsylvania}

\section{Summary and Conclusions}

The U.S. Geological Survey, in cooperation with the Southern Alleghenies Conservancy and the Borough of Martinsburg, conducted a study of the sources of water and contaminants to the Martinsburg municipal supply wells. The wells have a history of nitrate concentrations that approach and occasionally exceed the USEPA MCL. Multiple lines of evidence were used to delineate the areal extent of the zone of contribution to the Martinsburg municipal wells. Ground-water-flow modeling was used to estimate the potential areal extent of the zone of contribution on the land surface. Because of the complexities of modeling in carbonate terrain, geochemical indicators, analyses for anthropogenic contaminants, and microbial source tracking were used to assess the validity of the simulation results.

The simulation of ground-water flow was based on a conceptual model of areal recharge, flow through fractures that are equivalent to a porous media, and discharge to streams and pumping wells. The conceptual model included a highly fractured upper layer overlying a layer of more competent bedrock. The Woodbury Anticline controls the potential fracture patterns in the area, and therefore was assumed to control the aquifer framework near the well fields. Four carbonate-bedrock formations contain the primary aquifers. Three carbonate-bedrock aquifers of Ordovician age overlie the Gatesburg aquifer of Cambrian age on the flanks of the anticline. Sandstone and shale aquifers also were simulated in the ground-water model.

Geochemical data used to determine possible sources of water indicated well water representing a dolomite source for well BA 545 and a mixed limestone and dolomite source for well BA 332. The water-source types were in accordance with what would be expected on the basis of the geographic locations and primary aquifer of the wells. The results of geochemical analyses also indicated that conduits were not likely to be the dominant pathway for ground-water flow to most wells. Modeling was conducted assuming that conduit flow was not the dominant type of ground-water flow. Calcite saturation, specific conductance, alkalinity, and $\mathrm{PCO}_{2}$ all indicated fracture flow was the dominant pathway for ground water. Nevertheless, karst features are present and may have had a significant effect on localized patterns of ground-water flow.

Sampling for anthropogenic contaminants indicated ground water was significantly affected by human activities. Nitrate concentrations in water samples from wells in carbonate bedrock ranged from 5.7 to $36.9 \mathrm{mg} / \mathrm{L}$ as nitrogen. Both wells BA 545 and BA 332 had chloride/bromide ratios above the level indicating anthropogenic influence. Results of sampling for boron were inconclusive. Results of wastewater analyses and fecal-source tracking indicated human sewage was probably not the primary source of nitrogen in the ground water. Although not conclusive, the indications of the fecal-source tracking study showed the bacteria in most wells and streams to be closely aligned with bacteria from dairy manure rather than human sewage. Most of the evidence indicated bacteria and nitrate concentrations in wells in this study were from animalmanure sources; however, the areal extent of the zone of contribution and $\delta^{15} \mathrm{~N}$ values indicated chemical fertilizer was a likely source of much of the nitrogen in wells BA 332 and BA 545. Organic nitrogen sources (human sewage or animal manure) may have contributed some nitrogen to each of these wells and was a more likely source of nitrogen in well BA 332 .

The MODFLOW three-dimensional finite-difference model was used to simulate ground-water flow in the area near the Martinsburg well fields. Model results indicated the areal extent of the zone of contribution to wells BA 332 and BA 545. Parameter estimation was used to obtain the best fit between measured and simulated water levels. Measured water levels were generally in agreement with the simulation results. For this regression, the sum of squared residuals was 76.2. The rootmean-square error for the simulation was $2.2 \mathrm{ft}$. The relative agreement between simulated and measured water levels supported the assumption that flow through conduits was not a dominant pathway for ground-water flow. Fracture, not conduit, permeability was determined to be the dominant waterbearing characteristic of the bedrock. The horizontal hydraulic conductivity of the Gatesburg aquifer is about 36 feet per day. The other carbonate aquifers (Nittany/Stonehenge, Bellefonte/ Axemann, and Coburn through Loysburg aquifers) overlying and flanking the Gatesburg aquifer have horizontal hydraulic conductivities of about 1 foot per day. Regional directions of ground-water flow are toward the major streams with Clover Creek as the major discharge point for ground water in the east. The flow toward Clover Creek crosses minor topographic divides. Ground-water flow to the well fields is anisotropic with a 5:1 preferential horizontal direction that is oriented along the strike of the axial fold of the anticline, making the shape of the zone of contribution of ground water to the well fields elongated in a north-south direction along the anticline axis. The majority of the flow to the well fields originates from the south.

Results of the ground-water flow-model were supported by the other lines of evidence. Geochemical data used to determine possible sources of water indicated a mixture of ground waters consistent with that which would result if the model had correctly identified the aquifers producing the water to the municipal-supply wells. The comparison of the land use and the areal extent of the zone of contribution indicated that much of the zone of contribution was under agricultural or urban land. The substantial amount of agricultural land use in the areal extent of the zone of contribution explained the consistent, high nitrate concentrations detected in these wells. The $\delta^{15} \mathrm{~N}$ values, in well BA 545 particularly, indicated a source area with a high percentage of chemical fertilizer and a lower percentage of manure as a source of nitrogen. The areal extent of the zone of contribution to well BA 545 delineated by the model included several fields that have chemical fertilizer as the predominant source of nitrogen. 


\section{References Cited}

Bassett, R.L., Buszka, G.R., Davidson, G.R., and Chong-Diaz, D., 1995, Identification of ground water solute sources using boron isotopic composition: Environmental Science and Technology, v. 29, no. 12, p. 2,915-2,922.

Becher, A.E., 1996, Ground-water resources of Cambrian and Ordovician carbonate rocks in the Valley and Ridge Physiographic Province of Pennsylvania: U.S. Geological Survey Open-File Report 90-109, 134 p.

Berg, T.M., Edmunds, W.E., Geyer, A.R., Glover, A.D., Hoskins, D.M., MacLachlan, D.B., Root, S.I., Sevon, W.D., and Socolow, A.A., comps., 1980, Geologic map of Pennsylvania: Pennsylvania Geological Survey, 4th ser., scale $1: 250,000,2$ sheets.

Böhlke, J.F., 2003, Sources, transport, and reaction of nitrate, in Lindsey, B.D., Phillips, S.W., Donnelly, C.A., Speiran, G.K., Plummer, L.N., Böhlke, John-Karl, Focazio, M.J., Burton, W.J., and Busenberg, Eurybiades, Residence time and nitrate transport in ground water discharging to streams in the Chesapeake Bay Watershed: U.S. Geological Survey WaterResources Investigations Report 03-4035, 201 p.

Burton, W.C., Plummer, L.N., Busenberg, Eurybiades, Lindsey, B.D., and Gburek, W.J., 2002, Influence of fracture anisotropy on ground water ages and chemistry, Valley and Ridge Province, Pennsylvania: Ground Water, v. 40, no. 3, p. 242-257.

Butts, Charles, 1945, Hollidaysburg-Huntingdon folio, Pennsylvania: U.S. Geological Survey Geologic Atlas of the United States, Folio 227, 20 p.

Chin, C.V., 1996, Application and comparison of EPA wellhead protection delineation methods for karst aquifers, Centre County, Pennsylvania (Pennsylvania State University dissertation): Ann Arbor, Mich., UMI Dissertation Services, $328 \mathrm{p}$.

Coyle, Elizabeth, 1998, Morrisons Cove wells high in nitrates: Bedford, Pa., Gazette, April 10, 1998, p. 1.

Cravotta, C.A., III, 1997, Use of stable isotopes of carbon, nitrogen, and sulfur to identify sources of nitrogen in surface waters in the Lower Susquehanna River Basin, Pennsylvania: U.S. Geological Survey Water-Supply Paper 2497, 99 p.

Davis, S.N., Whittemore, D.O., and Fabryka-Martin, J., 1998, Uses of chloride/bromide ratios in studies of potable water: Ground Water, v. 36, p. 338-350.

Durlin, R.R., and Schaffstall, W.P., 2003, Water Resources Data, Pennsylvania, Water Year 2002, Volume 2. Susquehanna River Basin: U.S. Geological Survey Water-Data Report PA-02-2, 536 p.

Fishman, M.J., ed., 1993, Methods of analysis by the U.S. Geological Survey National Water Quality Laboratory-Determination of inorganic and organic constituents in water and fluvial sediments: U.S. Geological Survey Open-File Report 93-125, 217 p.
Fishman, M.J., and Friedman, L.C., 1989, Methods for determination of inorganic substances in water and fluvial sediments: U.S. Geological Survey Techniques of WaterResources Investigations, book 5, chap. A1, 545 p.

Fleeger, G.M., McElroy, T.A., and Moore, M. E., 2004, Hydrogeologic and well construction characteristics of the rocks of Pennsylvania: Pennsylvania Geological Survey, 4th ser., Water Resource Report 69, CD-ROM.

Gburek, W.J., Folmar, G.J., and Urban, J.B., 1998, Field data and ground-water modeling in a layered fractured aquifer: Ground Water, v. 37, no. 2, p. 175-184.

Gerhart, J.M., and Lazorchick, G.J., 1988, Evaluation of the ground-water resources of the Lower Susquehanna River Basin, Pennsylvania and Maryland: U.S. Geological Survey Water-Supply Paper 2284, 128 p.

Hagedorn, Charles, Robinson, S.L., Filtz, J.R., Grubbs, S.M., Angier, T.A., and Reneau, R.B., Jr., 1999, Determining sources of fecal pollution in a rural Virginia watershed with antibiotic resistance patterns in fecal streptococci: Applied and Environmental Microbiology, v. 65, p. 5,522-5,531.

Hainly, R.A., Zimmerman, T.M., Loper, C.A., and Lindsey, B.D., 2001, Summary of and factors affecting pesticide concentrations in streams and shallow wells of the Lower Susquehanna River Basin, Pennsylvania and Maryland, 199395: U.S. Geological Survey Water-Resources Investigations Report 01-4012, 75 p.

Harbaugh, A.W., Banta, E.R., Hill, M.C., and McDonald, M.G., 2000, MODFLOW-2000, The U.S. Geological Survey modular ground-water model-User guide to modularization concepts and the ground-water flow process: U.S. Geological Survey Open-File Report 00-92, 121 p.

Harwood, V.J., Whitlock, John, and Withington, Victoria, 2000, Classification of antibiotic resistance patterns of indicator bacteria by discriminant analysis-Use in predicting the source of fecal contamination in subtropical waters: Applied and Environmental Microbiology, v. 66, p. 3,6983,704.

Hem, J.D., 1985, Study and interpretation of the chemical characteristics of natural water: U.S. Geological Survey WaterSupply Paper 2254, 263 p.

Hill, M.C., Banta, E.R., Harbaugh, A.W., and Anderman, E.R., 2000, MODFLOW-2000, The U.S. Geological Survey modular ground-water model-User guide to the observation, sensitivity, and parameter estimation processes and three post-processing programs: U.S. Geological Survey OpenFile Report 00-184, 209 p.

Jagucki, M.L., and Darner, R.A., 2001, Ground-water quality in Geauga County, Ohio-Review of previous studies, status in 1999, and comparison of 1986 and 1999 data: U.S. Geological Survey Water-Resources Investigations Report 01-4160, $60 \mathrm{p}$.

Kendall, C., and Caldwell, E.A., 1998, Fundamentals of isotope geochemistry in Kendall, C., and McDonnell, J.J. (eds.), Isotope tracers in catchment hydrology: Amsterdam, Elsevier Science, p. 51-86. 


\section{References Cited—Continued}

Knuth, M., Jackson, J.L., and Whittemore, D.O., 1990, An integrated approach to identifying the salinity source contaminating a ground-water supply: Ground Water, v. 28, no. 2, p. 207-214.

Lamond, R.E., and Leikam, D.F., 2002, Chloride in KansasPlant, soil, and fertilizer considerations: Kansas State University MF-2570, $4 \mathrm{p}$.

Langmuir, D., and Jacobson, R.L., 1971, Hydrochemistry of ground waters in carbonate rocks near State College, Pennsylvania, in Parizek, W.B., White, W.B., and Langmuir, D., Hydrogeology and geochemistry of folded and faulted rocks of the Central Appalachian type and related land-use problems: University Park, Pa., Pennsylvania State University Circular 82, p. 126-133.

Langmuir, D., and White, W.B., 1971, Natural ground-water geochemistry, in Parizek, W.B., White, W.B., and Langmuir, D., Hydrogeology and geochemistry of folded and faulted rocks of the Central Appalachian type and related land-use problems: University Park, Pa., Pennsylvania State University Circular 82, p. 115-134.

Lindsey, B.D., Loper, C.A., and Hainly, R.A., 1997, Nitrate in ground water and stream base flow in the Lower Susquehanna River Basin, Pennsylvania and Maryland: U.S. Geological Survey Water-Resources Investigations Report 974146, $66 \mathrm{p}$.

Low, D.J., and Conger, R.W., 2002, Ground-water availability in part of the Borough of Carroll Valley, Adams County, Pennsylvania, and the establishment of a drought-monitor well: U.S. Geological Survey Water-Resources Investigations Report 02-4273, 78 p.

McDonald, M.G., and Harbaugh, A.W., 1988, A model of three-dimensional finite-difference ground-water flow model: U.S. Geological Survey Techniques of WaterResources Investigations, book 6, chap. A1, $586 \mathrm{p}$.

Miller, D.W., 1980, Waste disposal effects on ground waterA comprehensive survey of the occurrence and control of ground-water contamination resulting from waste-disposal practices: Berkeley, Calif., Premier Press, 512 p.

Risser, D.W., and Barton, G.J., 1995, A strategy for delineating the area of ground-water contributing to wells completed in fractured bedrock aquifers in Pennsylvania: U.S. Geological Survey Water-Resources Investigations Report 95-4033, $30 \mathrm{p}$.

Scanlon, B.R., Mace, R.E., Barrett, M.E., and Smith, Brian, 2003, Can we simulate regional ground water flow in a karst system using equivalent porous media models? Case study, Barton Springs Edwards aquifer, USA: Journal of Hydrology, v. 276, p. 137-158.

Scanlon, B.R., and Thrailkill, J., 1987, Chemical similarities among physically distinct spring types in a karst terrain: Journal of Hydrology, v. 89, p. 259-279.

Sevon, W.D., 2000, Physiographic provinces of Pennsylvania: Pennsylvania Geological Survey, 4th ser., scale 1:2,000,000.
Siwiec, S.F., Hainly, R.A., Lindsey, B.D., Bilger, M.D., and Brightbill, R.A., 1997, Water-quality assessment of the Lower Susquehanna River Basin, Pennsylvania and Maryland-Design and implementation of water-quality studies, 1992-95: U.S. Geological Survey Open-File Report 97-583, $121 \mathrm{p}$.

Sloto, R.A., and Crouse, M.Y., 1996, HYSEP-A computer program for streamflow hydrograph separation and analysis: U.S. Geological Survey Water-Resources Investigations Report 96-4040, 46 p.

Speece, Jack, and Cullinan, Mike, 1972, The caves of Blair County: Mid-Appalachian region of the National Speliological Society, Bulletin no. 8, 90 p.

Taylor, L.E., Werkheiser, W.H., duPont, N.S., and Kriz, M.L., 1982, Groundwater resources of the Juniata River Basin, Pennsylvania: Pennsylvania Geological Survey, 4th ser., Water-Resource Report 54, 131 p.

U.S. Department of Agriculture, 1981, Soil survey of Blair County, Pennsylvania: Washington, D.C., United States Department of Agriculture, Soil Conservation Service, scale $1: 20,000$.

U.S. Environmental Protection Agency, 1992, Consensus method for determining groundwaters under the direct influence of surface water using microscopic particulate analysis (MPA): EPA 910/9-92-029.

U.S. Environmental Protection Agency, 2002, National Primary Drinking-Water Standards: EPA 816-F-02-013, 7 p.

U.S. Geological Survey, 1997 to present, National field manual for the collection of water-quality data: U.S. Geological Survey Techniques of Water-Resources Investigations, book 9, chap. A4, 2 v., variously paged.

Vogelmann, J.E., Sohl, T.L., Campbell, P.V., and Shaw, D.M., 1998a, Regional land cover characterization using Landsat Thematic Mapper data and ancillary data sources: Environmental Monitoring and Assessment 51, p. 415-428.

Vogelmann, J.E., Sohl, T.L., and Howard, S.M.,1998b, Regional characterization of land cover using multiple sources of data: Photogrammetric Engineering and Remote Sensing 64, p. 45-57.

White, W.B., 1988, Geomorphology and hydrology of karst terrains: New York, Oxford University Press, 464 p.

Wiggins, B.A., Andrews, R.W., Conway, R.A., Corr, C.L., Dobratz, E.J., Dougherty, D.P., Eppard, J.R., Knupp, S.R., Limjoco, M.C., Mettenburg, J. M., Rinehardt, J.M., Sonsino, J., Torrijos, R.L., and Zimmerman, M.E., 1999, Use of antibiotic resistance analysis to identify nonpoint sources of fecal pollution: Applied and Environmental Microbiology, v. 65, p. 3,483-3,486.

Zaugg, S.D., Smith, S.G., Schroeder, M.P., Barber, L.B., and Burkhardt, M.R., 2002, Methods of analysis by the U.S. Geological Survey National Water Quality Laboratory-Determination of wastewater compounds by polystyrene-divinylbenzene solid-phase extraction and capillary-column gas chromatography/mass spectrometry: U.S. Geological Survey Water-Resources Investigations Report 01-4186, $37 \mathrm{p}$. 